\title{
Discovery of Pyrrolo[3,2-d]pyrimidin-4-one Derivatives as a New Class of Potent and Cell Active Inhibitors of P300/CBP-Associated Factor Bromodomain
}

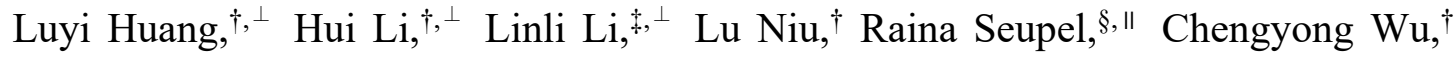
Wei Cheng, ${ }^{\dagger}$ Chong Chen, ${ }^{\dagger}$ Bisen Ding, ${ }^{\dagger}$ Paul E. Brennan, ${ }^{\S, \|}$ and Shengyong Yang ${ }^{*}, \dagger$

†State Key Laboratory of Biotherapy and Cancer Center, West China Hospital, Sichuan University, Chengdu 610041, P.R. China.

Key Laboratory of Drug Targeting and Drug Delivery System of Ministry of Education, West China School of Pharmacy, Sichuan University, Sichuan 610041, P.R. China ${ }^{\S}$ Structural Genomics Consortium, University of Oxford, Old Road Campus Research Building, Roosevelt Drive, Oxford OX3 7DQ, U.K.

"Target Discovery Institute, University of Oxford, NDM Research Building, Roosevelt Drive, Oxford OX3 7FZ, U.K.

\#These authors contributed equally to this work.

*To whom correspondence should be addressed. Shengyong Yang, State Key Laboratory of Biotherapy and Cancer Center, West China Hospital, Sichuan University, Chengdu, Sichuan 610041, China. E-mail: yangsy@scu.edu.cn. 


\section{ABSTRACT}

Herein we report the discovery of a series of new PCAF bromodomain (BRD) inhibitors, which were obtained through a hit discovery process and subsequent structure-based optimization and structure-activity relationship (SAR) analyses towards a retrieved hit compound (12). Among these inhibitors, $(R, R)-36 \mathbf{n}$ is the most potent one with an $\mathrm{IC}_{50}$ of $7 \mathrm{nM}$ in HTRF assay and a $\mathrm{K}_{\mathrm{D}}$ of $78 \mathrm{nM}$ in ITC assay. This compound also exhibited activity against GCN5 and FALZ, but weak or no activity against other 29 BRD proteins and 422 kinases, indicating considerable selectivity. X-ray cocrystal structure analysis revealed the molecular interaction mode and the precise stereochemistry required for bioactivity. Cellular activity, preliminary RNA-seq analysis and pharmacokinetic properties were also examined for this compound. Collectively, this study provides a versatile tool molecule to explore molecular mechanisms of PCAF BRD regulation and also offers a new lead compound for drug discovery targeting PCAF. 


\section{INTRODUCTION}

Bromodomains (BRDs) are highly conserved epigenetic "reader" protein modules that recognize $\varepsilon-N$-acetylated lysine marks on proteins, ${ }^{1}$ and play a key role in the epigenetic regulation of gene transcription. A total of 61 BRDs are identified in the human proteome, which present in 46 diverse proteins. ${ }^{2}$ Among these BRDs, BET (Bromo and extra-terminal) BRDs are the most extensively studied subfamily (subfamily II of BRD phylogenetic tree). A large number of selective and potent BET BRD inhibitors have been discovered, ${ }^{3,4}$ which have provided versatile tools for bio-functional studies, and further led to numerous translational studies on this subfamily of BRD proteins. ${ }^{5-9}$ In contrast, BRDs in non-BET subfamilies have received less attention. Biological functions of many non-BET BRDs in physiological and pathological conditions are still not clear, and inhibitors of these BRDs are also much less. ${ }^{10-12}$

P300/CBP-associated factor (PCAF), also known as lysine acetyltransferase 2B (KAT2B), is a BRD-containing protein, which belongs to subfamily I of the BRD phylogenetic tree. ${ }^{1} \mathrm{PCAF}$ is a multidomain protein including an acetyltransferase (HAT) domain, ${ }^{13}$ a $\mathrm{N}$-terminal E3 ubiquitin ligase domain, ${ }^{14}$ and a C-terminal bromodomain, ${ }^{15}$ which has been implicated in a number of disparate disease pathologies and small molecule modulators have great potential as therapeutics. ${ }^{16}$ Regulation mechanisms and roles in diseases of these domains, particularly the C-terminal bromodomain, are far from understood. Small molecule inhibitors might provide tool molecules to unravel the functions of the PCAF BRD on the one hand, on the other hand, offer potential lead compounds for drug development targeting PCAF BRD.

To date, a number of small-molecule inhibitors of PCAF BRD have been reported, which are summarized in Figure 1. Zeng et al. reported the first PCAF inhibitor 1, which could disrupt the PCAF-BRD/Tat-AcK50 interaction in vitro. ${ }^{17}$ Subsequent structural 
optimization of 1 generated a more potent compound $2 .{ }^{18}$ Navratilova et al. ${ }^{19}$ and Chaikuad et al. ${ }^{20}$ separately used fragment-based screening approaches to identify PCAF BRD inhibitors, and a number of inhibitors (fragments) were retrieved, for example, compound 3 and 4. In 2016, Genentech and Constellation disclosed potent dual PCAF/GCN5 BRDs inhibitors in three patents, and compounds 5-7 shown in Figure 1 are representative ones although no selectivity data was reported. ${ }^{21-23}$ Later, Brennan and coworkers reported a $[1,2,4]$ triazolo[3,4-a]phthalazine derivative, $8(\boldsymbol{L}$ Moses, Figure 1) as a potent, selective, and cell active PCAF probe. ${ }^{24}$ Researchers from GlaxoSmithKline published a potent PCAF/GCN5 BRDs inhibitor $9,{ }^{25}$ and very recently, they further derived a PROTAC compound (GSK699) from 9. ${ }^{26}$

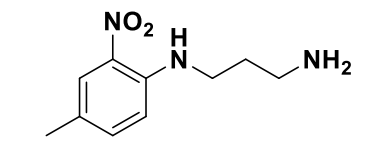

$\mathrm{IC}_{50}=1.6 \mathrm{M}$

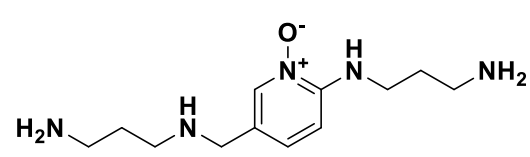

$\mathrm{IC}_{50}^{2}=0.9 \mathrm{M}$<smiles>C[C@H](Nc1nn(C)c(=O)n(C)c1=O)[C@H](c1ccc(S(=O)(=O)O)cc1)N(C)C</smiles>

$\mathrm{IC}_{50}=70 \mathrm{nM}$<smiles>CC(C)C[C@H]1C[C@@H](Nc2cnn(C)c(=O)c2Cl)CN(C)C1</smiles>

7

$\mathrm{IC}_{50}=13 \mathrm{nM}$<smiles>Cc1nnc2c3ccccc3c(NC(C)C(c3ccccc3)N(C)C)nn12</smiles>

8/L-Moses $K_{D}=126 \mathrm{nM}$

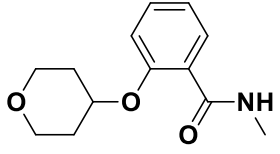

3<smiles>CC(Nc1nn(C)c(=O)c2cccnc12)C(c1ccccc1)N(C)C</smiles>

$\mathrm{IC}_{50}=19 \mathrm{nM}$<smiles>CN1CC(Nc2cnn(C)c(=O)c2Br)C[C@@H](c2ccccc2)C1</smiles>

9/GSK4027 $\mathrm{IC}_{50}=40 \mathrm{nM}$

Figure 1. Representative PCAF BRD inhibitors publicly reported.

Despite these recent advances, there are still very few reported potent and selective PCAF BRD inhibitors. The aim of this investigation was to identify more novel potent and selective PCAF BRD inhibitors. To achieve this goal, we first performed virtual screening (VS) against an in-house chemical database to retrieve hit compounds, which 
led to the discovery of three hits. The most potent hit compound, which contains a new pyrrolo[3,2-d]pyrimidin-4-one scaffold, was then selected for subsequent structural optimization. Structure-activity relationship (SAR) analyses resulted in the discovery of a series of new PCAF BRD inhibitors containing the scaffold pyrrolo[3,2d]pyrimidin-4-one. For the most active compound, further investigations including selectivity profiling, ligand-receptor interaction analysis, cellular activity, preliminary RNA-seq (RNA-sequencing) analysis and pharmacokinetic studies were carried out.

\section{RESULTS AND DISCUSSION}

\subsection{Retrieving of Hit Compounds}

To discover more potent PCAF BRD inhibitors with new scaffolds, we first conducted a virtual screening (VS) study against an in-house chemical database (details for the VS see Supporting Information Figure S1). Selected hit compounds in VS were then subjected to a differential scanning fluorimetry (DSF) assay at a compound concentration of $20 \mu \mathrm{M}$. Compounds with a thermal shift $\left(\Delta \mathrm{T}_{\mathrm{m}}\right)$ of $\geq 1{ }^{\circ} \mathrm{C}$ in the DSF assay were then validated by isothermal titration calorimetry (ITC) assay. We finally obtained three weakly active compounds, 10, 11, and 12, which showed $K_{D}$ values of 45, 7.8 and $2.4 \mu \mathrm{M}$ in the ITC assay, respectively (Figure 2). Compound 10 shows some similarity to previously reported $\mathrm{BRD} 7 / 9,{ }^{27} \mathrm{BAZ2A} / \mathrm{B},{ }^{28}$ and $\mathrm{CBP} / \mathrm{EP} 300{ }^{29,}{ }^{30} \mathrm{BRD}$ inhibitors and compound $\mathbf{1 1}$ contains the previously reported phthalazinone scaffold, ${ }^{22}$ but compound 12 harbors a new scaffold, pyrrolo[3,2-d]pyrimidin-4-one, which has not been reported previously in BRD inhibitors. We chose compound $\mathbf{1 2}$ to conduct further structural optimization because it is the most potent compound and has a novel scaffold. 
A
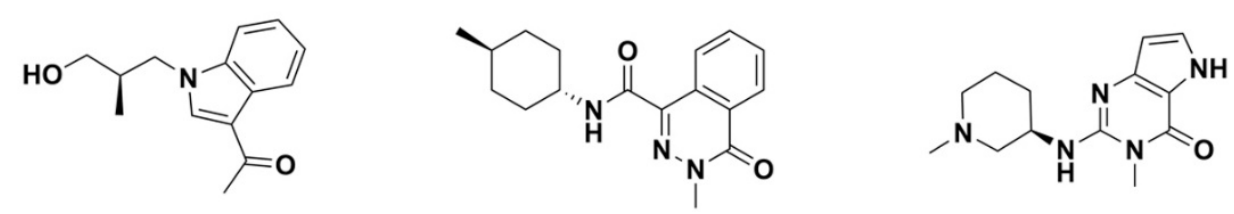

$\begin{gathered}10 \\ \Delta T m\end{gathered}=1.0^{\circ} \mathrm{C}$

11
$\Delta \mathrm{Tm}=1.0^{\circ} \mathrm{C}$

B
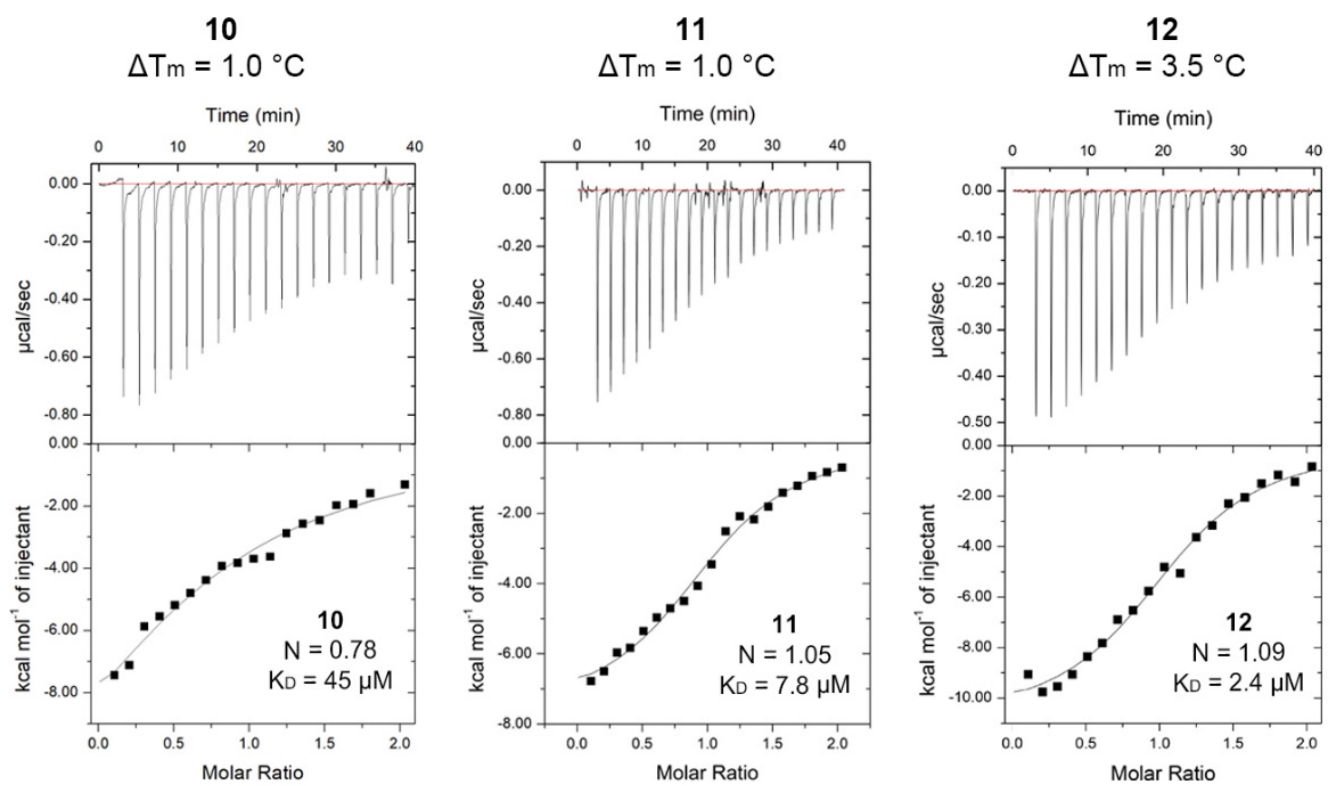

Figure 2. Three active compounds found by VS and subsequent bioactivity evaluation.

(A) Chemical structures of 10, 11, and 12. (B) Isothermal titration data of the interaction of hit compounds (for $\mathbf{1 0}$ and 11, $50 \mu \mathrm{M}$ ligand and $500 \mu \mathrm{M}$ PCAF BRD were used; for 12, $20 \mu \mathrm{M}$ ligand and $200 \mu \mathrm{M}$ PCAF were used) with PCAF BRD.

To facilitate the following structural optimization of 12, an X-ray cocrystal structure of PCAF in complex with 12 was solved with a resolution of $2.1 \AA$ resolution (PDB ID: 6J3O). As shown in Figure 3, compound 12 bound to the acetyllysine-binding site and had well defined by electron density. This compound forms hydrogen bonds with four amino acids, Pro747, Asn803, Tyr760, and Tyr809, either directly or via water-mediated interaction. The methyl substituent at the 3-position was in the water channel occupied by the acetyl lysine of the histone ligand. We also observed a $\pi-\pi$ stacking interaction between the pyrrolo[3,2-d]pyrimidin-4-one core and the benzene ring of Tyr809. The basic piperidine group forms a salt bridge with acidic side chain of 
Glu756, which is further stabilized by the backbone amide nitrogen of Lys753 through a hydrogen bond. Here it is necessary to mention that compound $\mathbf{1 2}$ seems to make the same interactions with PCAF BRD as compound $(R)-\mathbf{2 3}$ in reference 25, and the only difference is that compound $\mathbf{1 2}$ forms an additional hydrogen bond with Asn803.

\subsection{Structural Optimization and SAR Analyses of Pyrrolo[3,2-d]pyrimidin-4-one Derivatives}

Structural optimization of hit compound $\mathbf{1 2}$ was focused on three regions, namely, the 2-amino moiety (region I), the 3-position (region II) and the 5-position substituent (region III) of pyrrolo[3,2-d]pyrimidin-4-one (Figure 3C). A number of new pyrrolo[3,2-d]pyrimidin-4-one derivatives were designed and synthesized. Bioactivities of these compounds against PCAF BRD were measured by DSF and ITC assays.
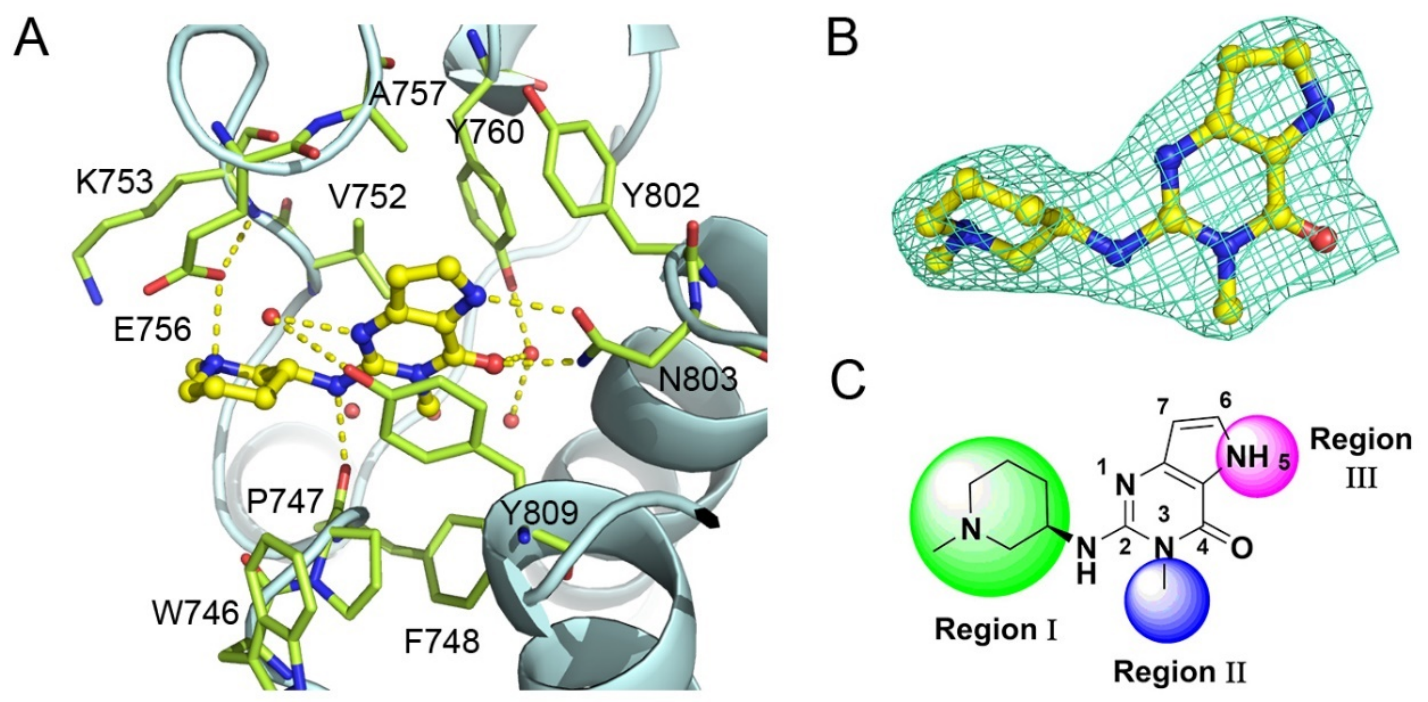

Figure 3. Cocrystal structure of PCAF/12 guided the structural optimization. (A)

Cocrystal structure of compound $\mathbf{1 2}$ (yellow sticks) in complex with PCAF bromodomain (pale cyan cartoon) (PDB ID: 6J3O). Related residues are shown as 
green sticks. (B) Experimental electron density map $\left(2 \mathrm{~F}_{\mathrm{o}}-\mathrm{F}_{\mathrm{c}}\right)$ contoured at $1 \sigma$ around the hit 12. (C) Focused regions in the structural optimization and SAR analyses.

\subsubsection{Impact of 2-Amino Moiety (Region I)}

To explore the impact of 2-amino moiety of compound $\mathbf{1 2}$ on the bioactivity, we varied region I and fixed region II and III with their original substituents. According to the cocrystal structure of 12-PCAF complex (Figure 3A), the basic $N$-methyl piperidine in region I, which forms a salt bridge with acidic Glu756, plays an important role to the ligand-receptor interaction. But the $N$-methyl piperidine group is not large enough to occupy the ZA channel. Accordingly, all substituents used in region I were required to contain a secondary or tertiary amine, and larger than $N$-methyl piperidine to make potential interactions with Trp746 and Lys753. Based on this observation and inspiration from the SAR study of compound $9,{ }^{25}$ we designed and synthesized a total of 10 compounds $((R, R)-\mathbf{2 4 a},(S, S)-\mathbf{2 4 a}$, cis-24b, endo-24c-e, endo-25a, exo-25a, and endo-26a-b).

Scheme 1 shows synthetic routes for these compounds. Commercially available 2,4-dichloro-5H-pyrrolo[3,2-d]pyrimidine (13) underwent alkaline hydrolysis to produce intermediate 14. Boc-protection of 14 gave 15. Subsequent methylation and Boc-deprotection of $\mathbf{1 5}$ generated the key intermediate 16. $(R) /(S)-\mathbf{1 7} \mathbf{a}$ or $\mathbf{1 7 b}$ (racemate) reacted with picolinic acid to produce $(R) /(S)$-18a or $\mathbf{1 8 b}$, which underwent $\mathrm{C}\left(\mathrm{sp}^{3}\right)-\mathrm{H}$ arylation with iodobenzene to afford enantiomerically pure $(R, R) /(S, S)-\mathbf{1 9 a}$ or $\operatorname{cis} \mathbf{- 1 9 b}$, respectively. ${ }^{31}$ Compounds $(R, R) /(S, S)-\mathbf{1 9 a}$ and $c i s-19 \mathbf{b}$ were further converted to $(R, R) /(S, S)$-20a and cis-20b by Boc-deprotection, reductive amination and subsequent alkaline hydrolysis. $(R, R) /(S, S)-\mathbf{2 0 a}$ and cis-20b together with two commercially available amines 21-22 were subjected to a tractable $S_{N} A r$ reaction with 16 to afford 
target products $(R, R)-\mathbf{2 4 a},(S, S)-\mathbf{2 4 a}$, cis-24b, and endo-24c-d. 23 (endo/exo mixture) reacted with 16 to afford endo- and exo-24e. Acidic $N$-deprotection of endo- and exo24e afforded endo- and exo-25a, respectively. $N$-alkylation of endo-25a with $(R)-2-$ phenyloxirane or $(R)$-2-bromo-1-(pyridin-2-yl)ethan-1-ol produced endo-26a-b.

Scheme 1. Synthesis of $(R, R)-24 \mathbf{a},(S, S)-\mathbf{2 4 a}$, cis-24b, endo-24c-e, endo-25a, exo-25a, and endo-26a-b ${ }^{\text {a }}$
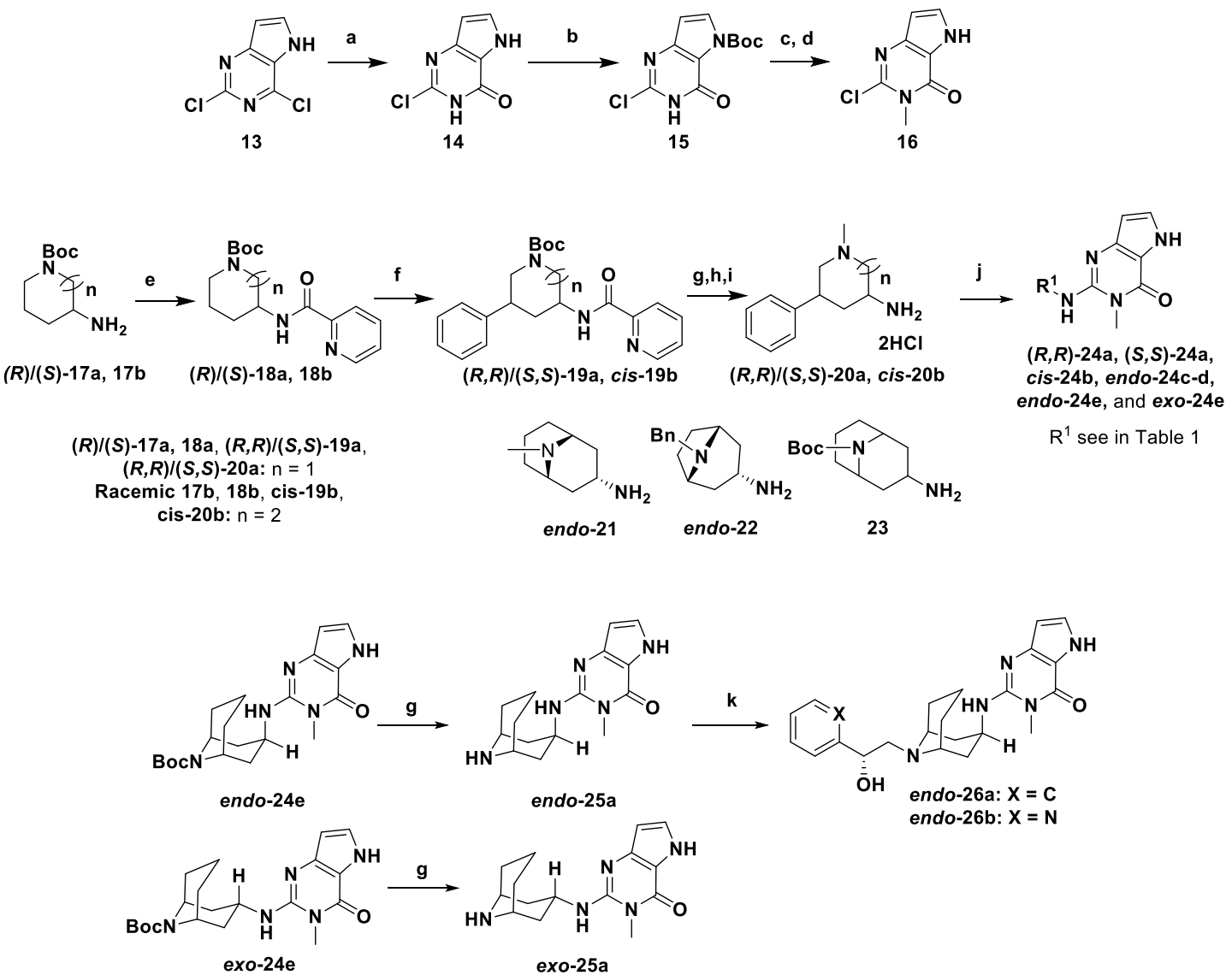

${ }^{a}$ Reagents and conditions: (a) $1 \mathrm{M} \mathrm{NaOH}$ (aq), $100{ }^{\circ} \mathrm{C}, 16 \mathrm{~h}, 90 \%$; (b) $\mathrm{Boc}_{2} \mathrm{O}$, TEA, DMAP, DMF, rt, 82\%; (c) iodomethane, NaH, anhydrous DMF, $40{ }^{\circ} \mathrm{C}$, overnight; (d) trifluoroacetic acid, DCM, rt, 46\% over two steps; (e) picolinic acid, HATU, DIPEA, DCM, rt, 83-88\%; (f) iodobenzene, $\mathrm{Pd}(\mathrm{OAc})_{2}, \mathrm{Ag}_{2} \mathrm{CO}_{3}, 2,6$-dimethylbenzoic acid, $t$ $\mathrm{BuOH}, 120{ }^{\circ} \mathrm{C}, 24 \mathrm{~h}, 62-77 \%,>99 \%$ ee; (g) trifluoroacetic acid, DCM, rt; (h) 37\% formaldehyde, $\mathrm{NaBH}(\mathrm{OAc})_{3}, \mathrm{AcOH}, \mathrm{DCM}, \mathrm{rt}, 8 \mathrm{~h}, 84 \%$; (i) $\mathrm{NaOH}, i-\mathrm{PrOH}, 85^{\circ} \mathrm{C}, 18$ 
h, 78-85\%; (j) 16, primary amines, DIPEA, NMP, $150{ }^{\circ} \mathrm{C}, 2-5$ h, 12-37\%; (k) (R)-2phenyloxirane or (R)-2-bromo-1-(pyridin-2-yl)ethan-1-ol, TEA, MeCN, $70{ }^{\circ} \mathrm{C}$, overnight, $47-58 \%$.

The synthesized compounds were assayed against the PCAF BRD and bioactivities of these compounds are presented in Table $1 .(R, R)$-24a, containing a $(R, R)-1$-methyl5-phenylpiperidin-3-amino group, showed a thermal shift $\left(\Delta \mathrm{T}_{\mathrm{m}}\right)$ of $6.3^{\circ} \mathrm{C}$ in DSF assay, and a $\mathrm{K}_{\mathrm{D}}$ of $152 \mathrm{nM}$ in ITC assay, whereas its enantiomer $(S, S)-\mathbf{2 4 a}$ lost activity. Cis24b with piperidine in $(R, R)$-24a replaced by azacycloheptane also displayed considerable activity in both assays $\left(\Delta \mathrm{T}_{\mathrm{m}}=3.2{ }^{\circ} \mathrm{C}\right.$ and $\left.\mathrm{K}_{\mathrm{D}}=347 \mathrm{nM}\right)$, but relatively weaker potency compared with those of $(R, R)$-24a. Among the remaining seven compounds containing a bridged piperidine, endo-24c was the most potent one $\left(\Delta \mathrm{T}_{\mathrm{m}}\right.$ $=7.3{ }^{\circ} \mathrm{C}$ and $\mathrm{K}_{\mathrm{D}}=0.215 \mu \mathrm{M}$ ). The $N$-methyl removal product endo-25a slightly decreased in bioactivity $\left(\Delta \mathrm{T}_{\mathrm{m}}=6.6^{\circ} \mathrm{C}\right.$ and $\left.\mathrm{K}_{\mathrm{D}}=0.242 \mu \mathrm{M}\right)$, whereas the diastereomer exo-25a did not exhibit activity. Endo-24e, endo-26a, and endo-26b with a bulky substituent in the bridged piperidine displayed a significant reduced activity in both assays. Endo-24d, which contains a 2-carbon-bridged piperidine (tropane), showed no activity.

Table 1. Bioactivities of Region I Substituted Compounds against PCAF BRD.

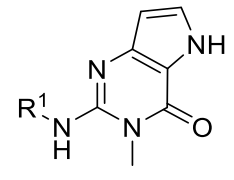
Compd
$\mathbf{R}^{1}$
$K_{\mathrm{D}}(\mu \mathrm{M})$
$\Delta T_{m}\left({ }^{\circ} C\right)^{a}$ 


en,R)-24a

${ }^{a}$ Values are averages of triplicates \pm SEM (2 $\mu \mathrm{M}$ PCAF, $10 \mu \mathrm{M}$ compound $)$.

\subsubsection{Influence of 3- and 5-Position Substitutions (Region II and III).}

To examine the influence of 3- and 5-position substitutions of pyrrolo[3,2d]pyrimidin-4-one core, we fixed 2-position (region I) with its optimal group, $(R, R)-1$ methyl-5-phenylpiperidin-3-amino, and varied the 3- or 5-position substituents. Six new compounds $((R, R)$-32a-f) were designed and synthesized (Scheme 2$)$; for the 3position substituents, we introduced unsaturated alkyl groups because it has been 
reported that unsaturated alkyl groups at this position might influence the bioactivity or selectivity across bromodomains. ${ }^{32}$ Intermediate $\mathbf{1 5}$ underwent an alkylation reaction with various haloalkanes followed by Boc-deprotection gave 27a-d. Methylation of $\mathbf{1 4}$ with methyl iodide afforded $\mathbf{2 8}$. Selective hydrolysis of 29 with $1 \mathrm{M} \mathrm{NaOH}$ generated 30, and methylation of $\mathbf{3 0}$ resulted in the formation of $\mathbf{3 1}$ in an excellent yield. Finally, 27a-d, 28, and 31 reacted with $(R, R)-20 a$ to produce $(R, R)-32 a-f$, respectively.

Scheme 2. Synthesis of $(R, R)-\mathbf{3 2} \mathbf{a}-\mathbf{f}^{\mathbf{a}}$
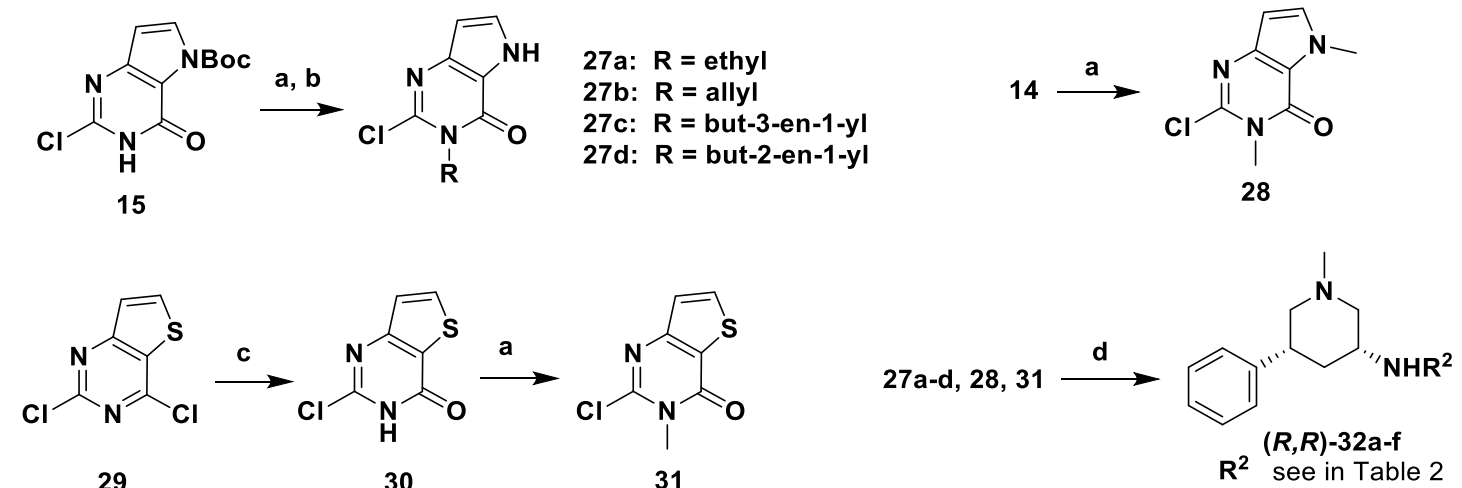

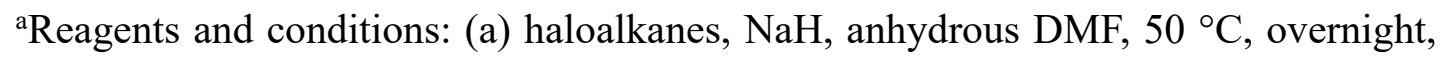
34-78\%; (b) trifluoroacetic acid, DCM, rt; (c) $1 \mathrm{M} \mathrm{NaOH}$ (aq), $100{ }^{\circ} \mathrm{C}, 95 \%$; (d) $(R, R)-$ 20a, DIPEA, NMP, $150{ }^{\circ} \mathrm{C}, 2 \mathrm{~h}, 13-47 \%$.

Table 2 shows the bioactivities of these compounds. From Table 2, we can see that the longer the (unsaturated) alkyl chain of 3-position, the worse the bioactivity $((R, R)-$ 32a-d), indicating that a bulky group at 3-position is unfavorable for bioactivity. To explore the impact of 5-position substitution of pyrrolo[3,2-d]pyrimidin-4-one, we firstly added a methyl group at 5-position. Bioactivity of the resulting compound $(R, R)$ 32e decreased significantly, implying that the hydrogen bond $(\mathrm{NH} \ldots \mathrm{O})$ is important and substitution at this position is not favored (see Figure 3A). Displacing the nitrogen 
atom on 5-position with a sulfur atom $((R, R)$-32f $)$ also decreased the binding affinity, demonstrated again the importance of the hydrogen bond ( $\mathrm{NH} . . \mathrm{O})$.

Table 2. Bioactivities of Compounds $(R, R)$-32a-f against PCAF BRD.

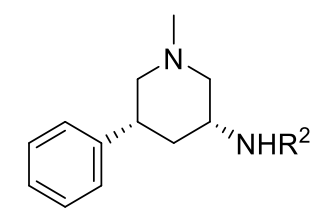

\begin{tabular}{|c|c|c|c|}
\hline Compd & $\mathbf{R}^{2}$ & $\mathbf{K}_{\mathbf{D}}(\boldsymbol{\mu} \mathbf{M})$ & $\Delta T_{m}\left({ }^{\circ} C\right)^{a}$ \\
\hline$(R, R)-\mathbf{3 2} \mathbf{a}$ & & 0.621 & $4.8 \pm 0.2$ \\
\hline$(R, R)-\mathbf{3 2} \mathbf{b}$ & & 0.676 & $2.2 \pm 0.6$ \\
\hline$(R, R)-\mathbf{3 2 c}$ & & 3.41 & $1.5 \pm 0.4$ \\
\hline$(R, R)-\mathbf{3 2 d}$ & & 3.04 & $1.5 \pm 0.4$ \\
\hline$(R, R)-\mathbf{3 2} \mathbf{e}$ & & $>10$ & $-0.2 \pm 0.4$ \\
\hline$(R, R)-\mathbf{3 2 f}$ & & 0.820 & $4.6 \pm 0.4$ \\
\hline
\end{tabular}

$\overline{{ }^{a}}$ Values are averages of triplicates \pm SEM $(2 \mu \mathrm{M}$ PCAF, $10 \mu \mathrm{M}$ compound $)$.

\subsubsection{Effect of Various Substituted 3-Amino-5-phenylpiperidine (Region I)}

In preceding structural optimization, we obtained a potent compound, $(R, R)-\mathbf{2 4 a}$. SAR analyses indicated that any changes in region II and III were not favored for bioactivity improvement. We thus turned back to recheck region I, and examined the 
possible effect of various substituents on the piperidine ring $\left(\mathrm{R}^{3}\right.$ and $\left.\mathrm{R}^{4}\right)$. Fifteen compounds $((R, R)-36 \mathbf{a}-\mathbf{n}$ and $(S, S)-36 \mathbf{n})$ were synthesized.

Scheme 3 outlines the reaction routes for these compounds. Compound $(R, R)$ - or $(S, S)$-18a reacted with various aryl iodides via $\mathrm{C}\left(\mathrm{sp}^{3}\right)-\mathrm{H}$ arylation to afford enantiomerically pure $(R, R)-\mathbf{1 9} \mathbf{a},(R, R)-\mathbf{3 3 a} \mathbf{a} \mathbf{j}$ and $(S, S)-\mathbf{1 9} \mathbf{a} \cdot{ }^{31}$ Compounds $(R, R)-\mathbf{1 9 a}$, $(R, R)-33 \mathbf{a}-\mathbf{j}$ and $(S, S)-\mathbf{1 9 a}$ were further converted to $(R, R)-\mathbf{3 4 a} \mathbf{a}-\mathbf{m}$ and $(S, S)-\mathbf{3 4 m}$ by Boc-deprotection and subsequent reductive amination or nucleophilic substitution. Cleavage of the bidentate directing groups of $(R, R)-\mathbf{3 4 a}-\mathbf{m}$ and $(S, S)-\mathbf{3 4} \mathbf{m}$ with the use of $\mathrm{NaOH} / i$-PrOH resulted in amines $(R, R)$-35a-m and $(S, S)-\mathbf{3 5 m}$, which were subjected

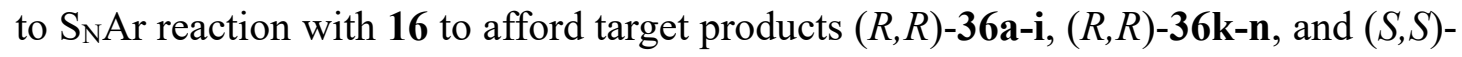
36n. $\mathrm{Pd} / \mathrm{C}$ catalyzed debenzylation of $(R, R)-\mathbf{3 6 i}$ produced $(R, R)-\mathbf{3 6 j}$.

Scheme 3. Synthesis of Compounds $(R, R)-\mathbf{3 6 a}-\mathbf{n}$ and $(S, S)-\mathbf{3 6} \mathbf{n}^{\mathrm{a}}$ 


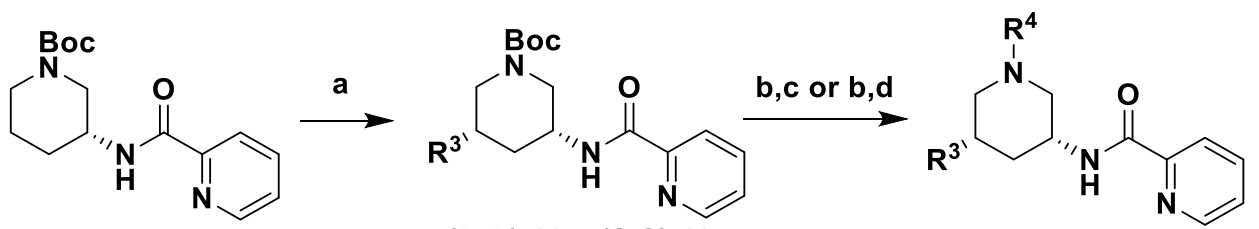

(R)-18a, (S)-18a

(R,R)-19a, (S,S)-19a,

$(R, R)-33 a-j$

(R,R)-34a-m, (S,S)-34m,

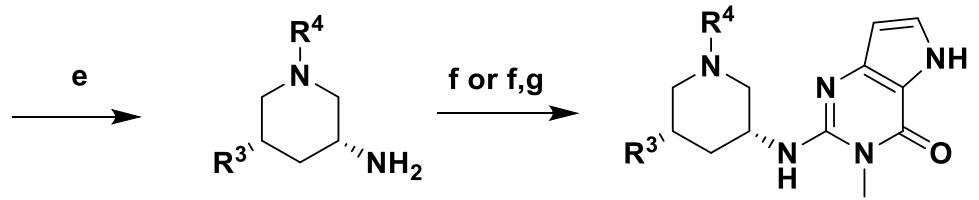

$(R, R)-35 a-m,(S, S)-35 m$,

$(R, R)-36 a-n,(S, S)-36 n$

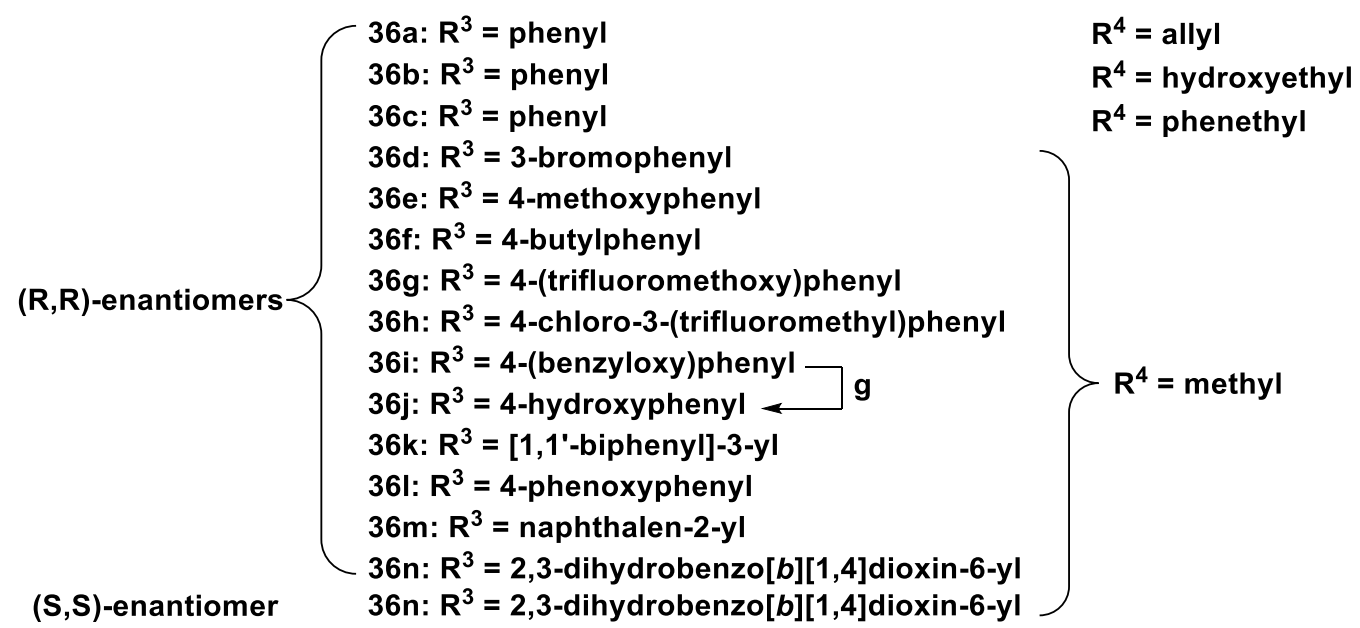

${ }^{a}$ Reagents and conditions: (a) aryl iodides, $\mathrm{Pd}(\mathrm{OAc})_{2}, \mathrm{Ag}_{2} \mathrm{CO}_{3}, 2$,6-dimethylbenzoic acid, $t-\mathrm{BuOH}, 120{ }^{\circ} \mathrm{C}, 24 \mathrm{~h}, 52-76 \%,>99 \%$ ee; (b) trifluoroacetic acid, DCM, rt; (c) haloalkanes, TEA, MeCN, $80{ }^{\circ} \mathrm{C}$, overnight, 76\%; (d) $37 \%$ formaldehyde (aq), $\mathrm{NaBH}(\mathrm{OAc})_{3}, \mathrm{AcOH}, \mathrm{DCM}$, rt, 73\%; (e) $\mathrm{NaOH}, i$-PrOH, $85^{\circ} \mathrm{C}, 18$ h; (f) 16, DIPEA, NMP, $150{ }^{\circ} \mathrm{C}, 2$ h, 11-26\%; (g) $(R, R)-36 i, 10 \% \mathrm{Pd} / \mathrm{C}, \mathrm{H}_{2}, \mathrm{MeOH}, \mathrm{rt}, 65 \%$.

Bioactivities of these compounds are shown in Table 3. Increasing the size of $N$ alkyl substituent $\left(\mathrm{R}^{4}\right)$ from methyl to allyl $((R, R)-\mathbf{3 6 a})$, hydroxyethyl $((R, R)-\mathbf{3 6 b})$, and phenethyl $((R, R)-36 \mathbf{c})$ decreased the bioactivity. Meta- and/or para-substituted phenyl groups at $\mathrm{R}^{3}((R, R)-\mathbf{3 6 d}-\mathbf{l})$ delivered potent activities, which are comparable to those of $(R, R)-24 \mathbf{a} .(R, R)-36 \mathbf{m}$, bearing a naphthalene-2-yl, enhanced the activity $\left(\mathrm{K}_{\mathrm{D}}: 0.103\right.$ $\mu \mathrm{M})$. (R,R)-36n with $\mathrm{R}^{3}$ substituted by 2,3-dihydro-1,4-benzodioxin-6-yl showed the 
most potent activity among all the synthesized compounds $\left(\mathrm{K}_{\mathrm{D}}: 0.078 \mu \mathrm{M}, \Delta \mathrm{T}_{\mathrm{m}}: 9.5^{\circ} \mathrm{C}\right)$ (Figure 4A and 4C). Of special note is that the enantiomer $(S, S)-\mathbf{3 6 n}$ showed no obvious activity.

Table 3. Bioactivities of Compounds $(R, R)-36 \mathbf{a}-\mathbf{n}$ and $(S, S)-\mathbf{3 6 n}$ against PCAF BRD

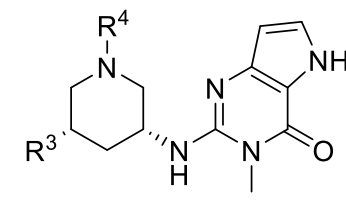

$(R, R)-36 \mathbf{a}-\mathbf{n}$<smiles>[R]C1CC(Nc2nc3cc[nH]c3c(=O)n2C)CN([R])C1</smiles>

$(S, S)-36 n$

\begin{tabular}{|c|c|c|c|c|}
\hline Compd & $\mathbf{R}^{3}$ & $\mathbf{R}^{4}$ & $K_{D}(\mu M)$ & $\Delta T_{m}\left({ }^{\circ} C\right)^{a}$ \\
\hline$(R, R)-\mathbf{3 6} \mathbf{a}$ & & & 0.233 & $4.4 \pm 0.3$ \\
\hline$(R, R)-\mathbf{3 6} \mathbf{b}$ & & $\mathrm{HO}^{-}$ & 0.535 & $4.7 \pm 0.3$ \\
\hline$(R, R)-\mathbf{3 6 c}$ & & & 1.20 & $2.5 \pm 0.7$ \\
\hline$(R, R)-\mathbf{3 6 d}$ & & $\mathrm{CH}_{3}$ & 0.128 & $7.5 \pm 0.4$ \\
\hline$(R, R)-\mathbf{3 6 e}$ & & $\mathrm{CH}_{3}$ & 0.106 & $8.0 \pm 0.4$ \\
\hline$(R, R)-\mathbf{3 6 f}$ & & $\mathrm{CH}_{3}$ & 0.183 & $4.6 \pm 0.9$ \\
\hline$(R, R)-\mathbf{3 6} \mathbf{g}$ & & $\mathrm{CH}_{3}$ & 0.140 & $5.9 \pm 0.3$ \\
\hline$(R, R)-\mathbf{3 6 h}$ & & $\mathrm{CH}_{3}$ & 0.138 & $6.6 \pm 0.3$ \\
\hline$(R, R)-\mathbf{3 6} \mathbf{i}$ & & $\mathrm{CH}_{3}$ & 0.118 & $6.7 \pm 0.9$ \\
\hline$(R, R)-\mathbf{3 6} \mathbf{j}$ & & $\mathrm{CH}_{3}$ & 0.120 & $8.4 \pm 0.3$ \\
\hline
\end{tabular}




\begin{tabular}{|c|c|c|c|}
\hline$(R, R)-36 \boldsymbol{k}$ & $\mathrm{CH}_{3}$ & 0.100 & $5.6 \pm 0.3$ \\
\hline$(R, R)-\mathbf{3 6} \mathbf{l}$ & $\mathrm{CH}_{3}$ & 0.085 & $6.9 \pm 0.5$ \\
\hline$(R, R)-\mathbf{3 6} \mathbf{m}$ & $\mathrm{CH}_{3}$ & 0.103 & $6.6 \pm 0.4$ \\
\hline$(R, R)-\mathbf{3 6} \mathbf{n}$ & $\mathrm{CH}_{3}$ & 0.078 & $9.5 \pm 0.5$ \\
\hline$(S, S)-\mathbf{3 6 n}$ & $\mathrm{CH}_{3}$ & $>10$ & $0.7 \pm 0.3$ \\
\hline
\end{tabular}

${ }^{\mathrm{a}}$ Values are averages of triplicates \pm SEM $(2 \mu \mathrm{M}$ PCAF, $10 \mu \mathrm{M}$ compound).

\subsection{Validation of Top Active Compounds by Biochemical Assay}

In the above SAR studies, DSF and ITC assays were used to measure the bioactivity of the synthesized compounds, and a number of active compounds were identified. Because both DSF and ITC belong to biophysical assay, we then used homogeneous time-resolved fluorescence (HTRF) assay, which is a biochemical assay, to further validate the bioactivity. Here just the top active compounds were tested. As shown in Table 4, all of the tested compounds showed high potency in the HTRF assay. $(R, R)-36 \mathrm{n}$ is again the most active one with an $\mathrm{IC}_{50}$ of $7 \mathrm{nM}$. For comparison, we also tested the bioactivity of $\boldsymbol{L}$-Moses, which showed an $\mathrm{IC}_{50}$ of $36 \mathrm{nM}$ in the HTRF assay (Figure 4B).

Table 4. Biochemical Activities (HTRF, $\mathrm{IC}_{50}$ ) of Compounds That Showed Potent Activity in ITC and DSF Assays.

\begin{tabular}{cccc}
\hline Compd & IC $_{\mathbf{5 0}}(\boldsymbol{\mu M})$ & Compd & IC $_{\mathbf{5 0}}(\boldsymbol{\mu M})$ \\
\hline$(R, R)-\mathbf{2 4 a}$ & 0.041 & $(R, R)-36 \mathbf{i}$ & 0.014
\end{tabular}




\begin{tabular}{cccc} 
endo-24c & 0.073 & $(R, R)-\mathbf{3 6} \mathbf{j}$ & 0.030 \\
endo-25a & 0.125 & $(R, R)-36 \boldsymbol{k}$ & 0.025 \\
$(R, R)-36 \mathbf{d}$ & 0.022 & $(R, R)-\mathbf{3 6} \mathbf{1}$ & 0.010 \\
$(R, R)-36 \mathbf{e}$ & 0.032 & $(R, R)-\mathbf{3 6} \mathbf{m}$ & 0.047 \\
$(R, R)-36 \mathbf{f}$ & 0.035 & $(R, R)-36 \mathbf{n}$ & 0.007 \\
$(R, R)-36 \mathbf{g}$ & 0.017 & $\boldsymbol{L}-\mathbf{M o s e s}$ & 0.036 \\
$(R, R)-\mathbf{3 6 h}$ & 0.030 & & \\
\hline
\end{tabular}

Overall, the above structural optimization and SAR studies finally led to the discovery of compound $(R, R)-\mathbf{3 6} \mathbf{n}$, which is among the most potent PCAF BRD inhibitors currently reported. Subsequently, further studies including selectivity profiling, interaction mode analyses, cellular activity evaluation, preliminary RNA-seq analysis, and pharmacokinetic studies were conducted on $(R, R)-\mathbf{3 6} \mathbf{n}$. 
A<smiles>CN1C[C@H](c2ccc3c(c2)OCCO3)C[C@@H](Nc2nc3cc[nH]c3c(=O)n2C)C1</smiles>

$(R, R)-36 n$
B

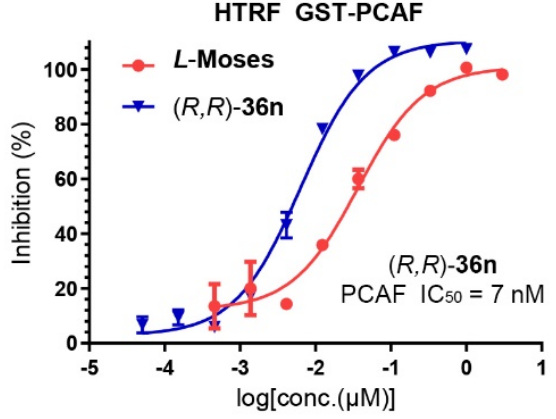

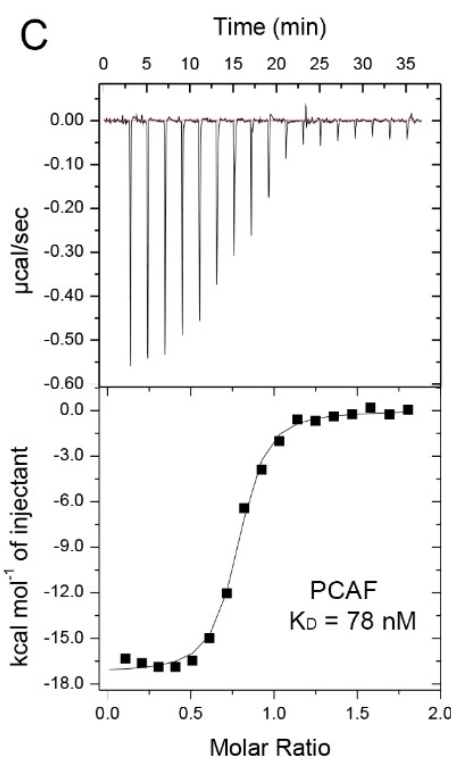
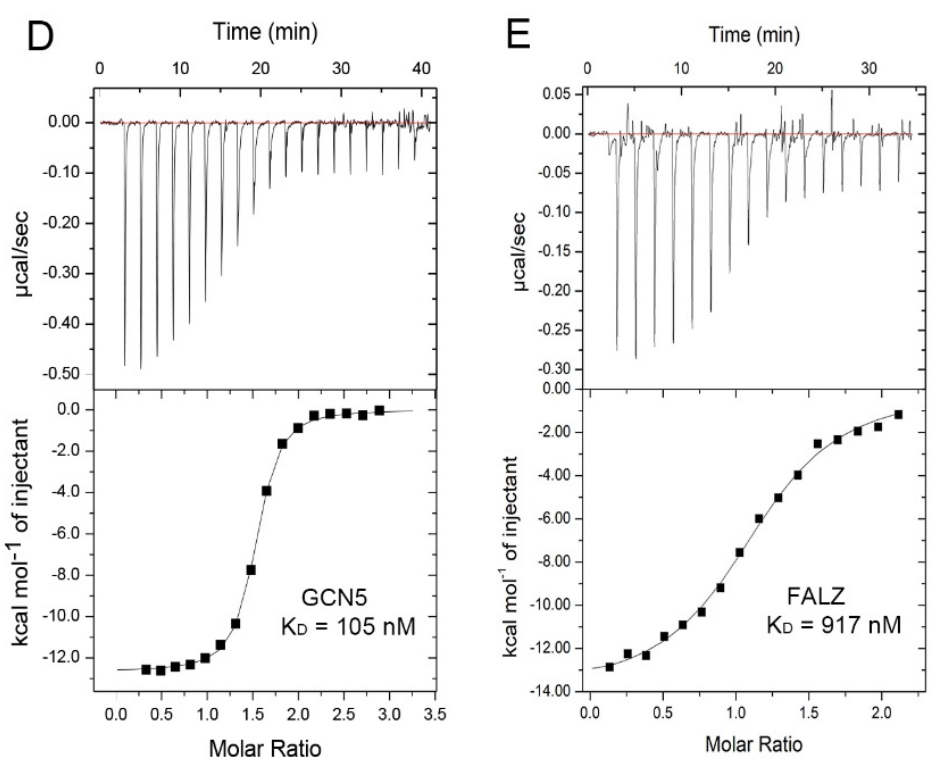

Figure 4. Identification of $(R, R)-\mathbf{3 6} \mathbf{n}$ as a potent inhibitor of PCAF bromodomain. (A) Chemical structure of $(R, R)-36 \mathbf{n}$. (B) HTRF assays of $(R, R)$-36n and $\boldsymbol{L}$-Moses on GSTPCAF. (C, D, E) ITC titration curves for the binding of $(R, R)-36 \mathbf{n}(10 \mu \mathrm{M}, 200 \mu \mathrm{L}$ in cell) to PCAF (C, $100 \mu \mathrm{M}, 40 \mu \mathrm{L}$ in syringe), GCN5 (D, $160 \mu \mathrm{M}, 40 \mu \mathrm{L}$ in syringe) and FALZ (E, $125 \mu \mathrm{M}, 40 \mu \mathrm{L}$ in syringe).

\subsection{Selectivity of $(R, R)-36 n$.}

To examine the selectivity of $(R, R)-\mathbf{3 6 n}$, we first used the DSF assay to measure activities of this compound against a panel of 12 BRDs available in our laboratory. $(R, R)$-36n showed the highest $\Delta \mathrm{T}_{\mathrm{m}}\left(9.5^{\circ} \mathrm{C}\right)$ against PCAF. Besides PCAF, it also exhibited potent activity against $\operatorname{GCN} 5\left(\Delta \mathrm{T}_{\mathrm{m}}=7.3{ }^{\circ} \mathrm{C}\right)$ and $\operatorname{FALZ}\left(\Delta \mathrm{T}_{\mathrm{m}}=5.3{ }^{\circ} \mathrm{C}\right)$. To verify these activities, ITC was then used to determine the binding affinities of $(R, R)$ - 
36n against GCN5 and FALZ, which gave $K_{D}$ values of $105 \mathrm{nM}$ and $917 \mathrm{nM}$, respectively (Figure 4D and 4E). This is not strange because PCAF BRD, GCN5 BRD and FALZ BRD are highly homologous and share 69\% sequence similarity. For the other 9 BRDs tested, $(R, R)-36$ n displayed obviously weak or no activity (Figure 5A, Supporting Information Table S1).

Further, the commercial BROMOscan assay was used to test the activity of this compound against a panel of 32 BRDs. Consistent with the results from previous DSF assays, $(R, R)-36 \mathbf{n}(1 \mu \mathrm{M})$ showed potent activity against PCAF, GCN5, and FALZ. It also showed activity but much weaker against CECR2, BRPF, and BAZ2 families. For the remaining 23 BRDs, $(R, R)-36$ n did not show activity (Figure 5B, Supporting Information Table S2).

In addition, we also tested the activity of $(R, R)$-36n against a panel of 422 kinases by Eurofins KinaseProfiler. Here a single concentration $(10 \mu \mathrm{M})$ of $(R, R)-\mathbf{3 6 n}$ was used. The results showed that $(R, R)-\mathbf{3 6 n}$ had no activity against all these kinases (see Supporting Information Table S3).

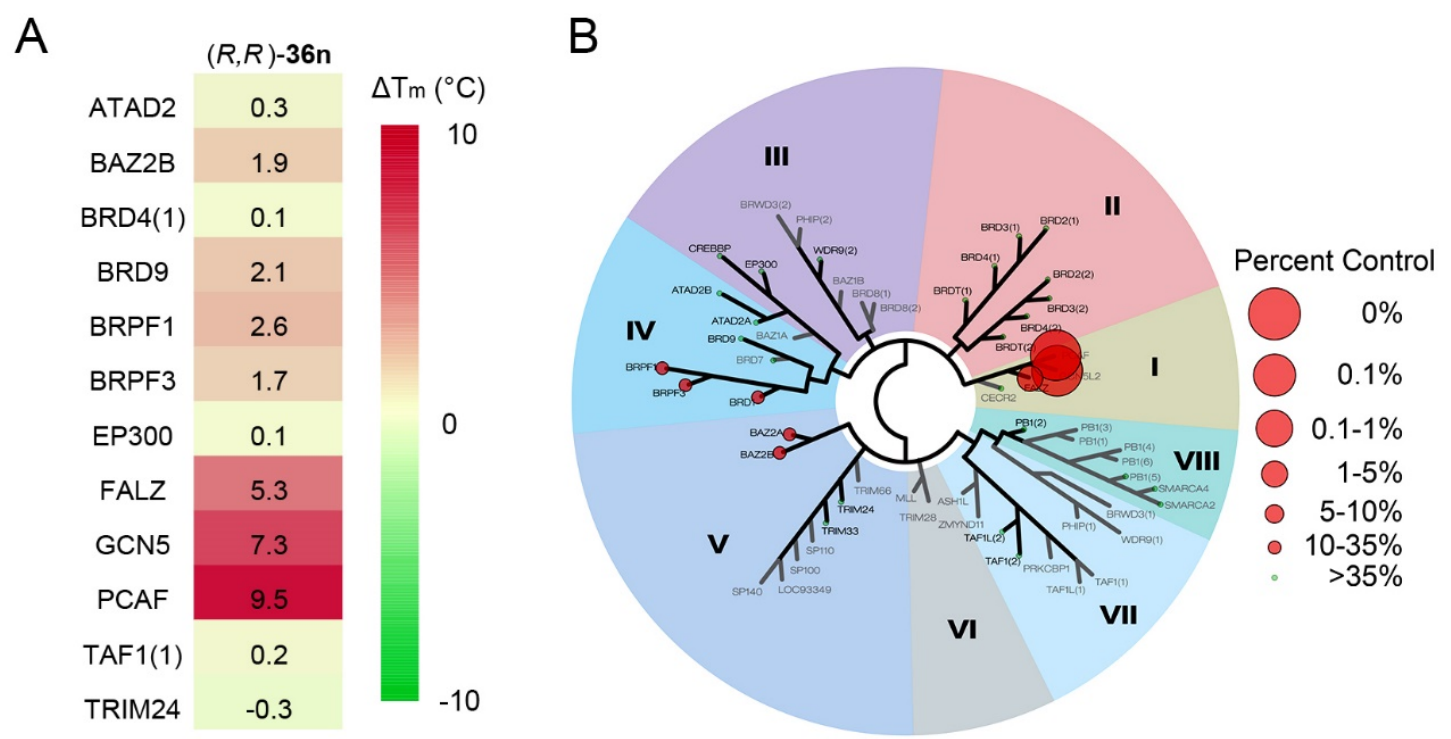

Figure 5. Selectivity of $(R, R)-36 \mathbf{n}$. (A) Thermal shift analysis of $(R, R)-36 \mathbf{n}(10 \mu \mathrm{M})$ against 12 BRDs, which belong to six distinct BRD subfamilies. The concentrations of 
BRDs used were $2 \mu \mathrm{M}$. The heat map shows the relative $\Delta \mathrm{T}_{\mathrm{m}}$, where the red color indicates a positive $\Delta \mathrm{T}_{\mathrm{m}}$ value and the green color indicates a negative $\Delta \mathrm{T}_{\mathrm{m}}$ value. (B) DiscoverX BROMOscan bromodomain cross-screen of $(R, R)-36 \mathbf{n}$ at $1 \mu \mathrm{M}$. Binding activity is expressed as a percentage of the control.

\subsection{Interaction Mode of $(R, R)-36 n$ with its Receptor.}

To understand the interaction mode of $(R, R)-\mathbf{3 6 n}$ with PCAF BRD, we tried to culture the cocrystal of $(R, R)$-36n with PCAF BRD. Unfortunately, it was unsuccessful for some unknown reasons. We thus transferred to culture the cocrystal of $(R, R)-\mathbf{3 6 n}$ bound to GCN5 BRD. As shown in Figure 6, $(R, R)$-36n occupies the KAc (acetylated lysine) binding site. Interactions found in the 12-BRD complex (Figure 3A), including hydrogen bonding, $\pi$-stacking interaction, and salt bridge, all exist in the $(R, R)$ 36n/BRD complex. Besides, we observed an additional edge-to-face aromatic interaction between the 2,3-dihydro-1,4-benzodioxine group and $\operatorname{Trp} 751$ in the $(R, R)$ 36n/BRD complex, which may explain the higher activity of $(R, R)-36 \mathbf{n}$ compared with that of 12 .
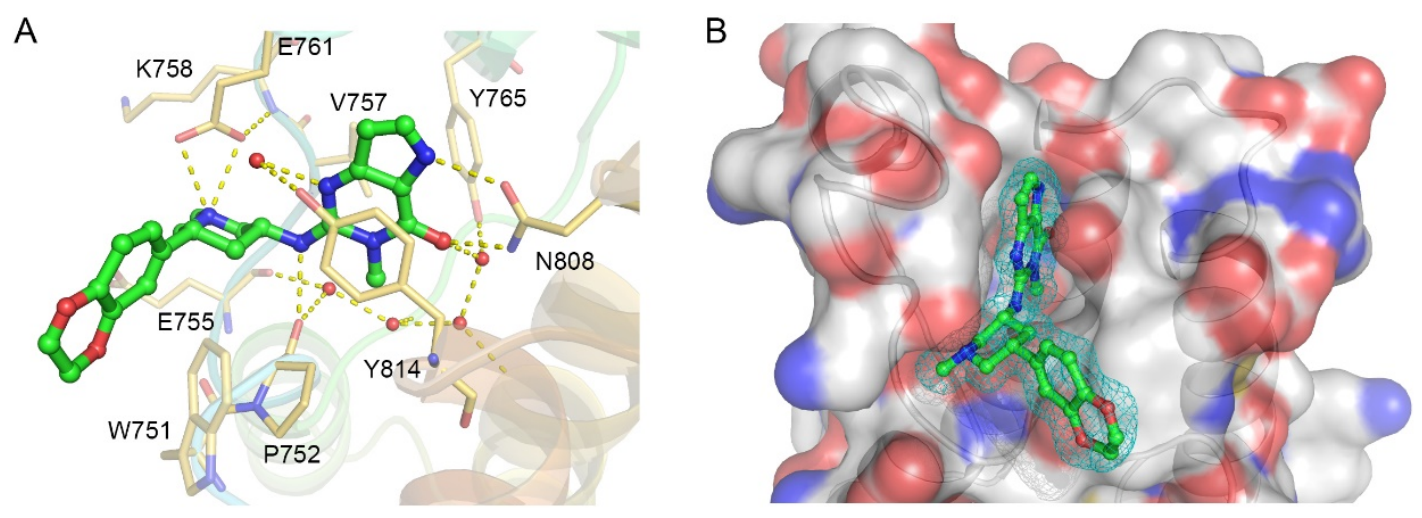

Figure 6. Structure and binding mode of $(R, R)-36 n$. (A) X-ray cocrystal structure of $(R, R)-36 n$ (green sticks) bound to GCN5 bromodomain (PDB ID: 6J3P), with conserved water network depicted (red spheres), yellow dashed lines indicate hydrogen 
bonds or salt bridges. (B) Surface view of the complex of GCN5 and $(R, R)-36 \mathbf{n}$. Mesh: $2 \mathrm{Fo}-\mathrm{Fc}$ omitted electron density map contoured at $1.0 \sigma$.

\subsection{Bioactivity of $(R, R)-36 n$ in Intact Cells.}

The NanoBRET assay was adopted to assess the cell permeability and target engagement potential of $(R, R)-36 \mathbf{n} \cdot{ }^{33}$ HEK293T cells were co-transfected with NanoLuc-tagged full-length PCAF and Halo-tagged histone H3.3 (Promega). The tagged PCAF-histone interaction in intact cells could be disrupted by competition with the test compound. In this assay, $(R, R)-\mathbf{3 6} \mathbf{n}$ showed clear dose-dependent displacement of full length PCAF-NanoLuc from histone H3.3-HaloTag in HEK293T cells with an $\mathrm{IC}_{50}$ of $118 \mathrm{nM}$, indicating that $(R, R)-\mathbf{3 6 n}$ could pass through the cell membrane and target PCAF, whereas the enantiomer $(S, S)$-36n displayed no effect (Figure 7).

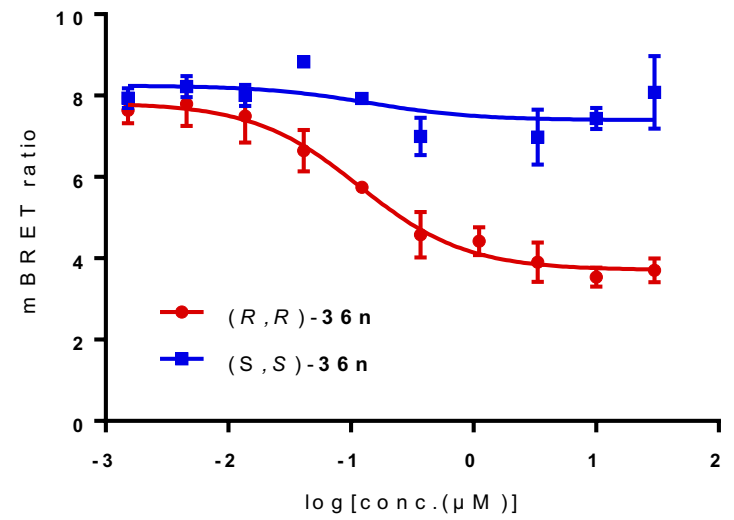

Figure 7. NanoBRET dose-response curves of $(R, R)-36 \mathbf{n}$ and $(S, S)-36 \mathbf{n}$ after $24 \mathrm{~h}$ treatment using $N$-terminal-nanoLuc-PCAF and C-terminal HaloTag-H3.3 in HEK293T cells (Graph represents $n=2$ biological replicates).

\subsection{Effect of $(R, R)-36$ n on Global Gene Expression.}

RNA-seq (RNA-sequencing) analysis was adopted to explore the effect of $(R, R)$ - 
36n $(2.5 \mu \mathrm{M})$ on global gene expression. In this assay, $(S, S)-36 \mathbf{n}(2.5 \mu \mathrm{M})$ and DMSO were taken as negative and blank controls, respectively. Mouse embryonic fibroblast (MEF) cells were used. MEF cells were treated for $48 \mathrm{~h}$ in advance, and then collected for RNA-seq analysis. RNA from each set $(\mathrm{n}=3)$ was used to analyze the global gene expression. As illustrated in Figure 8, treatment of $(R, R)-36 \mathbf{n}$ significantly influenced the expression of 58 genes ( $>1.5$-fold), among which 49 genes (39 up-regulated and 10 down-regulated) were uniquely impacted by $(R, R)-\mathbf{3 6 n}$, which might be attributed to the role of PCAF/GCN5 BRDs. Even so, the biology significance of the gene up or down regulation needs further in-depth studies.
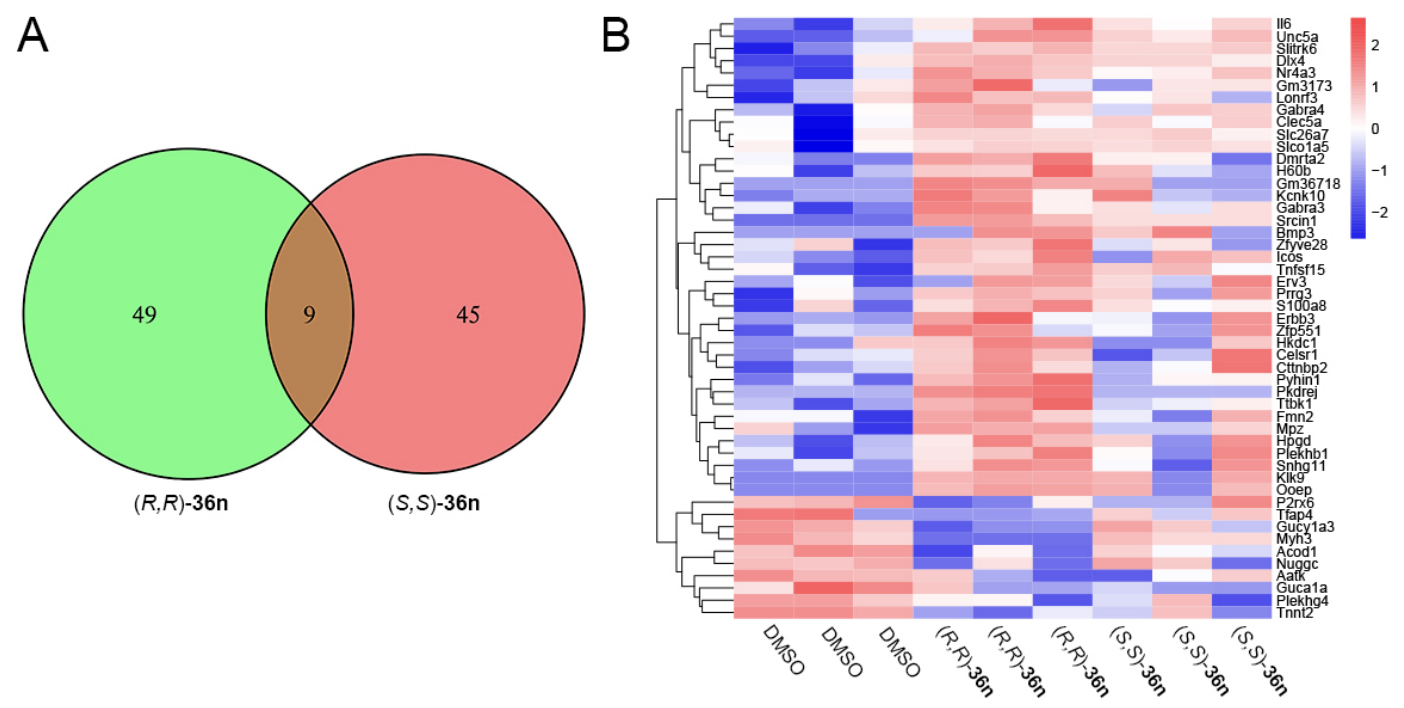

Figure 8. Effect of $(R, R)-36 \mathbf{n}$ on global gene expression. (A) Venn diagram showing number of genes significantly up- or down-regulated greater than 1.5 fold $(\mathrm{p}<0.05)$ following $(R, R)-36 \mathbf{n},(S, S)-\mathbf{3 6 n}$ or DMSO treatment for $48 \mathrm{~h}$ in MEF cells. Green circle represents the number of influenced genes by $(R, R)-\mathbf{3 6 n}$ relative to blank control, red circle means differential gene of $(S, S)$-36n relative to blank control. (B) Hierarchical clustering heat map of selected genes showing differential regulation by $(R, R)-\mathbf{3 6} \mathbf{n}$ and $(S, S)-36 n$ [genes up- or down-regulated by $>1.5$-fold and $\mathrm{p}<0.05$ of $(R, R)-36 \mathbf{n}$ ]. Data from three donors are shown for each experiment. 


\subsection{A Preliminary Assessment for the Pharmacokinetic Properties of $(R, R)-36 n$.}

The pharmacokinetic characteristics of $(R, R)$-36n were assessed on rats. A dose of $10 \mathrm{mg} / \mathrm{kg}$ was administrated through intravenous infusion or oral administration (for the blood concentration-time profiles, see Supporting Information Figure S3). The key oral administration pharmacokinetic parameters calculated are summarized in Table 4. The area under the concentration-time curve $\left(\mathrm{AUC}_{0-\infty}\right)$ is $2486 \mathrm{~h} \cdot \mathrm{ng} / \mathrm{mL}$. The half-life $\left(\mathrm{T}_{1 / 2}\right)$ and the maximum plasma concentration $\left(\mathrm{C}_{\max }\right)$ are $1.51 \mathrm{~h}$ and $1418 \mathrm{ng} / \mathrm{mL}$, respectively. Importantly, $(R, R)-36$ n has an excellent bioavailability of $52 \%$. In addition, the measured in vitro clearance of $(R, R)-\mathbf{3 6 n}$ is $45 \mathrm{~mL} / \mathrm{min} / \mathrm{kg}$ in human liver microsomes (Supporting Information Table S5). The aqueous solubility and $\log \mathrm{D}_{\mathrm{pH} 7.4}$ measured by HPLC are $480 \mu \mathrm{M}$ and 1.9 , respectively. Because it is the unbound drug that drives efficacy according to the free drug hypothesis, we thus determined the fraction unbound $\left(\mathrm{fu}_{\mathrm{b}}\right)$ in the Sprague-Dawley rat plasma, which gave an average value of $5.8 \%$. All of these results indicate that $(R, R)-36$ n possesses favorable pharmacokinetic properties.

Table 4. Key Pharmacokinetic Parameters of $(R, R)-36 n$ (p.o.).

\begin{tabular}{cc}
\hline Parameter & Value $^{\mathbf{a}}$ \\
\hline $\mathrm{T}_{1 / 2}(\mathrm{~h})$ & $1.51 \pm 0.23$ \\
$\mathrm{~T}_{\max }(\mathrm{h})$ & $0.67 \pm 0.29$ \\
$\mathrm{C}_{\max }(\mathrm{ng} / \mathrm{mL})$ & $1418 \pm 252$ \\
$\mathrm{AUC}_{(0-\mathrm{t})}(\mathrm{h} \cdot \mathrm{ng} / \mathrm{mL})$ & $2479 \pm 399$ \\
$\mathrm{AUC}_{(0-\infty)}(\mathrm{h} \cdot \mathrm{ng} / \mathrm{mL})$ & $2486 \pm 403$ \\
$\mathrm{~F}(\%)$ & $52 \pm 8.3$ \\
\hline
\end{tabular}


${ }^{\text {a }}$ Expressed as Mean $\pm \mathrm{SD}, \mathrm{n}=3$

\section{CONCLUDING REMARKS}

In this investigation, we discovered a potent PCAR BRD inhibitor, $(R, R)-36 \mathbf{n}$. This compound contains a new scaffold, pyrrolo[3,2-d]pyrimidin-4-one. Besides, it also contains a substituted piperidine, which is a common feature and presents in two other reported series of active compounds ( 7 and 9 in Figure 1). ${ }^{23,25}$ In addition to the PCAF inhibition, $(R, R)-36$ n also showed activity against GCN5 and FALZ, but displayed very weak or no activity against other 29 BRDs and 422 kinases, indicating considerable selectivity. Interestingly, the enantiomer $(S, S)$-36n did not show activity against PCAF, implying that $(R, R)$-36n could be a very suitable probe in investigating the biologic functions of PCAF. RNA-seq analysis demonstrated that $(R, R)-\mathbf{3 6 n}$ treatment affected the expression of 49 genes on MEF cells. However, the effects of the gene expression changes on biological functions are unknown, which needs further in-depth studies. Overall, we have obtained a potent and selective PCAF inhibitor. Nevertheless, the exploring of biological functions and medicinal applications of this compound still needs intensive studies.

\section{EXPERIMENTAL PROCEDURES}

4.1. Chemistry. All reagents and solvents were purchased from commercial suppliers without further purification unless otherwise indicated. All reactions were monitored by thin-layer chromatography (TLC) and visualized with UV light, ninhydrin stain, or iodine stain. Column chromatography was performed on pre-packed silica gel columns using a Biotage Isolera One flash purification system (LPLC). HPLC was performed 
on a Waters 2695 HPLC system. Gemini C18 reversed-phase column (4.6 mm $\Phi \times 150$ $\mathrm{mm}, 5 \mu \mathrm{m}$ ) was used for purity analysis, solubility and $\log \mathrm{D}$ determinations and Daicel Chiralpak IE chiral column (part no. 85325; $4.6 \mathrm{~mm} \Phi \times 150 \mathrm{~mm} ; 5 \mu \mathrm{m}$ ) for enantiomeric excess (ee) determination. ${ }^{1} \mathrm{H}$ NMR and ${ }^{13} \mathrm{C}$ NMR spectra were recorded on a Bruker AV-400 spectrometer. Coupling constants (J) are expressed in hertz (Hz). Chemical shifts are reported as parts per million (ppm) relative to an internal solvent reference. The following abbreviations were used in the NMR descriptions: s, singlet; d, doublet; t, triplet; q, quartet; m, multiplet; dd, double doublet; and br, broad peak. High-resolution ESI-MS data were recorded on an Agilent 1200-G6410A mass spectrometer. Purity of screening compounds were evaluated by NMR spectroscopy and HPLC analysis. All compounds had purity $\geq 95 \%$ by HPLC.

2-chloro-3-methyl-3H,4H,5H-pyrrolo[3,2-d]pyrimidin-4-one (16). Step 1. 2,4dichloro-5H-pyrrolo[3,2-d]pyrimidine $(\mathbf{1 3}, 25 \mathrm{~g}, 133 \mathrm{mmol})$ was added to $200 \mathrm{~mL} 1 \mathrm{M}$ $\mathrm{NaOH}$ solution and stirred at $100{ }^{\circ} \mathrm{C}$ for 16 hours. Upon cooling to rt, the dark brown solution was acidified to $\mathrm{pH} 5$ with $3 \mathrm{~N} \mathrm{HCl}$. The precipitate was collected by filtration onto a sintered-glass funnel, washed with water $(2 \times 50 \mathrm{~mL})$, and dried in vacuo to give 2-chloro-3H,4H,5H-pyrrolo[3,2-d]pyrimidin-4-one (14, $20.3 \mathrm{~g}, 120 \mathrm{mmol}, 90 \%)$ as a brown solid. ${ }^{1} \mathrm{H}$ NMR (400 MHz, DMSO-d 6 ) $\delta 12.81(\mathrm{~s}, 1 \mathrm{H}), 12.25$ (s, 1H), 7.41 (t, $J$ $=3.0 \mathrm{~Hz}, 1 \mathrm{H}), 6.35(\mathrm{dd}, J=2.8,2.0 \mathrm{~Hz}, 1 \mathrm{H})$.

Step 2. Compound 14 (20.3 g, $120 \mathrm{mmol})$, $\mathrm{Boc}_{2} \mathrm{O}$ (28.7 g, $\left.132 \mathrm{mmol}\right)$, triethylamine (13.3 g, $132 \mathrm{mmol}$ ), and DMAP (500 mg, $2.25 \mathrm{mmol}$ ) were suspended in $150 \mathrm{~mL}$ DMF. 
The mixture was stirred overnight at ambient temperature. Then $450 \mathrm{~mL}$ water was added and the resulting solution was acidified to $\mathrm{pH} 6$ with citric acid. The precipitate was collected by filtration onto a sintered-glass funnel, washed with water $(2 \times 50 \mathrm{~mL})$, and dried in vacuo to give tert-butyl 2-chloro-4-oxo-3H,4H,5H-pyrrolo[3,2d]pyrimidine-5-carboxylate $(\mathbf{1 5}, 26.6 \mathrm{~g}, 98.6 \mathrm{mmol}, \mathbf{8 2} \%)$ as a brown solid. The product was used without further purification. ${ }^{1} \mathrm{H}$ NMR (400 MHz, DMSO- $\left.d_{6}\right) \delta 13.07(\mathrm{~s}, 1 \mathrm{H})$, $7.85(\mathrm{~d}, J=3.5 \mathrm{~Hz}, 1 \mathrm{H}), 6.55(\mathrm{~d}, J=3.5 \mathrm{~Hz}, 1 \mathrm{H}), 1.58(\mathrm{~s}, 9 \mathrm{H})$.

Step 3. NaH (60\% in mineral oil, $1.9 \mathrm{~g}, 47.5 \mathrm{mmol})$ was added portionwise to a stirred solution of $\mathbf{1 5}(8.7 \mathrm{~g}, 32.3 \mathrm{mmol})$ in anhydrous DMF $(100 \mathrm{~mL})$ at $0{ }^{\circ} \mathrm{C}$. Twenty minutes later, iodomethane $(6.67 \mathrm{~g}, 47 \mathrm{mmol})$ was added and the mixture was reacted at $40{ }^{\circ} \mathrm{C}$ overnight. After cooling to rt, the mixture was carefully diluted with water and extracted with ethyl acetate (EtOAc). The combined organic phase was added trifluoroacetic acid (TFA) and stirred for another 5 hours. Then the solvent was removed under reduced pressure. The residue was purified by Biotage Isolera LPLC to give $\mathbf{1 6}$ $(2.7 \mathrm{~g}, 14.7 \mathrm{mmol}, 46 \%)$ as a white solid. ${ }^{1} \mathrm{H}$ NMR (400 MHz, DMSO- $\left.d_{6}\right) \delta 12.28(\mathrm{~s}$, $1 \mathrm{H}), 7.43(\mathrm{t}, J=2.9 \mathrm{~Hz}, 1 \mathrm{H}), 6.35(\mathrm{t}, J=2.2 \mathrm{~Hz}, 1 \mathrm{H}), 3.62(\mathrm{~s}, 3 \mathrm{H}) .{ }^{13} \mathrm{C} \mathrm{NMR}(101 \mathrm{MHz}$, DMSO-d6) $\delta 154.30,142.50,141.19,129.18,116.20,102.98,32.96$.

tert-butyl (3R)-3-(pyridine-2-amido)piperidine-1-carboxylate $((\boldsymbol{R})$-18a). To a stirred solution of picolinic acid (11.1 g, $130 \mathrm{mmol})$, tert-butyl (3R)-3-[(pyridin-2yl)amido]piperidine-1-carboxylate $((R)-17 a, 25.0 \mathrm{~g}, 125 \mathrm{mmol})$, and DIPEA (15.0 g, $155 \mathrm{mmol})$ in DCM $(250 \mathrm{~mL})$ was added HATU $(50.0 \mathrm{~g}, 131.5 \mathrm{mmol})$. The mixture was stirred at ambient temperature overnight, and concentrated under reduced pressure. 
The residue was dissolved in EtOAc $(200 \mathrm{~mL})$ and washed with $0.05 \mathrm{M} \mathrm{HCl}(2 \times 100$ $\mathrm{mL})$ and sat. aq $\mathrm{NaHCO}_{3}(2 \times 100 \mathrm{~mL})$. The organic layer was concentrated in vacuo and purified by Biotage Isolera LPLC to give the title compound $(R)-\mathbf{1 8 a}(32.1 \mathrm{~g}, 107$ mmol, 84\%) as a white solid. ${ }^{1} \mathrm{H}$ NMR (400 MHz, DMSO- $\left.d_{6}\right) \delta 8.64(\mathrm{dt}, J=4.7,1.3$ $\mathrm{Hz}, 1 \mathrm{H}), 8.55(\mathrm{~d}, J=8.2 \mathrm{~Hz}, 1 \mathrm{H}), 8.10-7.97(\mathrm{~m}, 2 \mathrm{H}), 7.61(\mathrm{ddd}, J=7.4,4.8,1.5 \mathrm{~Hz}$, $1 \mathrm{H}), 3.96-3.43(\mathrm{~m}, 3 \mathrm{H}), 3.26-2.77(\mathrm{~m}, 2 \mathrm{H}), 1.93-1.79(\mathrm{~m}, 1 \mathrm{H}), 1.79-1.58(\mathrm{~m}$, 2H), $1.57-1.20(\mathrm{~m}, 10 \mathrm{H})$. Chiral HPLC (Chiralpak IE-H column, $4.6 \mathrm{~mm} \times 25 \mathrm{~cm}$, $20 \% i-\mathrm{PrOH} /$ hexane, $1 \mathrm{~mL} / \mathrm{min}): \mathrm{R}_{\mathrm{t}}=25.86 \mathrm{~min},>99 \%$ ee.

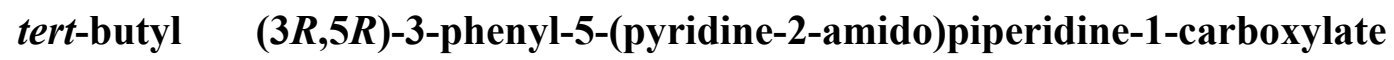
$((\boldsymbol{R}, \boldsymbol{R})-19 a)$. A pressure vial $(250 \mathrm{~mL})$ equipped with a magnetic stirring bar was charged with compound $(R)-\mathbf{1 8 a}(7.2 \mathrm{~g}, 23.6 \mathrm{mmol})$, iodobenzene $(24.1 \mathrm{~g}, 117.89$ mmol), silver carbonate $(6.5 \mathrm{~g}, 23.6 \mathrm{mmol})$, palladium acetate $(529 \mathrm{mg}, 2.36 \mathrm{mmol})$, 2,6-dimethylbenzoic acid (885 $\mathrm{mg}, 5.9 \mathrm{mmol})$, and $60 \mathrm{~mL} t$-BuOH. The vessel was flushed with argon, sealed with a crimp cap, and heated to $120^{\circ} \mathrm{C}$. After $24 \mathrm{~h}$, the reaction vessel was removed from the oil bath, cooled to room temperature, and added DCM $(60 \mathrm{~mL})$ to the reaction mixture. The mixture was thoroughly stirred for $10 \mathrm{~min}$, and the solids were removed by filtration. The filtrate was concentrated under reduced pressure and purified by Biotage Isolera LPLC to give the title compound $(R, R)-19 \mathbf{a}$ $(6.91 \mathrm{~g}, 18.1 \mathrm{mmol}, 77 \%)$ as a white solid. ${ }^{1} \mathrm{H}$ NMR (400 MHz, DMSO- $\left.d_{6}\right) \delta 8.74-$ $8.62(\mathrm{~m}, 2 \mathrm{H}), 8.10-7.96(\mathrm{~m}, 2 \mathrm{H}), 7.61(\mathrm{ddd}, J=7.4,4.7,1.4 \mathrm{~Hz}, 1 \mathrm{H}), 7.38-7.20(\mathrm{~m}$, 5H), $4.17-3.91(\mathrm{~m}, 3 \mathrm{H}), 2.91-2.63(\mathrm{~m}, 3 \mathrm{H}), 2.08-1.92(\mathrm{~m}, 2 \mathrm{H}), 1.43(\mathrm{~s}, 9 \mathrm{H})$. Chiral HPLC (Chiralpak IE-H column, $4.6 \mathrm{~mm} \times 25 \mathrm{~cm}, 20 \%$ EtOH/hexane, $1 \mathrm{~mL} / \mathrm{min}$ ): $\mathrm{R}_{\mathrm{t}}=$ 
$31.52 \mathrm{~min},>99 \%$ ee.

$(3 R, 5 R)-1-m e t h y l-5-p h e n y l p i p e r i d i n-3-a m i n e \quad$ dihydrochloride $((R, R)-20 a)$.

Step 1. To a stirred solution of $(R, R)-19 \mathrm{a}(6.8 \mathrm{~g}, 17.8 \mathrm{mmol})$ in DCM $(80 \mathrm{~mL})$ was added trifluoroacetic acid $(6 \mathrm{~mL})$. The resulting mixture was stirred at room temperature for $4 \mathrm{~h}$. The solvent was removed under reduced pressure and the crude product was redissolved in water $(60 \mathrm{~mL})$. The solution was basified to $\mathrm{pH} 10$ with $15 \%$ aq. $\mathrm{NaOH}$ and extracted twice with EtOAc. The combined organic layer was dried over anhydrous $\mathrm{Na}_{2} \mathrm{SO}_{4}$, filtered, and concentrated in vacuo to give $N$-[(3R,5R)-5phenylpiperidin-3-yl]pyridine-2-carboxamide (4.72 g, $16.8 \mathrm{mmol}, 94 \%)$ as a paleyellow solid that required no further purification.

Step 2. A stirred solution of $N$-[(3R,5R)-5-phenylpiperidin-3-yl]pyridine-2carboxamide $(3.2 \mathrm{~g}, 9.03 \mathrm{mmol})$ in methanol $(80 \mathrm{~mL})$ was treated with glacial acetic acid $(0.1 \mathrm{~mL})$ and $37 \% \mathrm{w} / \mathrm{v}$ formaldehyde in water $(1.1 \mathrm{~mL})$, then with sodium triacetoxyborohydride $(4.1 \mathrm{~g}, 19.33 \mathrm{mmol})$ portionwise ( $1.25 \mathrm{~g}$ every $20 \mathrm{~min}) .2 \mathrm{~h}$ after the final addition, the solvent was removed in vacuo and the residue was partitioned between EtOAc and water. The aqueous phase was extracted twice with EtOAc, and the combined organics were washed with brine, dried over anhydrous $\mathrm{Na}_{2} \mathrm{SO}_{4}$, filtered, and concentrated. Purification of the residue by Biotage Isolera LPLC gave $N-[(3 R, 5 R)-$ 1-methyl-5-phenylpiperidin-3-yl]pyridine-2-carboxamide (2.82 g, $9.55 \mathrm{mmol}, 84 \%$ ) as a white solid. ${ }^{1} \mathrm{H}$ NMR (400 MHz, DMSO- $\left.d_{6}\right) \delta 8.64(\mathrm{dt}, J=4.8,1.3 \mathrm{~Hz}, 1 \mathrm{H}), 8.56(\mathrm{~d}$, $J=8.7 \mathrm{~Hz}, 1 \mathrm{H}), 8.08-7.95(\mathrm{~m}, 2 \mathrm{H}), 7.60(\mathrm{ddd}, J=7.3,4.7,1.5 \mathrm{~Hz}, 1 \mathrm{H}), 7.36-7.25$ (m, 4H), $7.25-7.16(\mathrm{~m}, 1 \mathrm{H}), 4.20-4.06(\mathrm{~m}, 1 \mathrm{H}), 2.98-2.80(\mathrm{~m}, 3 \mathrm{H}), 2.24(\mathrm{~s}, 3 \mathrm{H})$, 
$2.01-1.84(\mathrm{~m}, 3 \mathrm{H}), 1.75(\mathrm{q}, J=12.2 \mathrm{~Hz}, 1 \mathrm{H})$.

Step 3. To a suspension of $N$-[(3R,5R)-1-methyl-5-phenylpiperidin-3-yl]pyridine2-carboxamide $(2.8 \mathrm{~g}, 9.48 \mathrm{mmol})$ in $i$ - $\mathrm{PrOH}(80 \mathrm{~mL})$ was added $\mathrm{NaOH}(3.8 \mathrm{~g}, 95$ mmol). The mixture was stirred at $85{ }^{\circ} \mathrm{C}$ for $18 \mathrm{~h}$. Then the solvent was removed under reduced pressure and water $(50 \mathrm{~mL})$ was added. The solution was extracted with EtOAc $(50 \mathrm{~mL} \times 2)$. The combined organic layer was dried over anhydrous $\mathrm{Na}_{2} \mathrm{SO}_{4}$, filtered, and added $15 \% \mathrm{HCl}$ in ethanol $(1 \mathrm{~mL})$. Finally the solvent was removed in vacuo to give $(R, R)-20 a(2.11 \mathrm{~g}, 85 \%, 8.0 \mathrm{mmol})$ as a pale-white solid. ${ }^{1} \mathrm{H}$ NMR $(400 \mathrm{MHz}$, DMSO-d $)_{6} \delta 11.78(\mathrm{~s}, 1 \mathrm{H}), 8.80(\mathrm{~s}, 3 \mathrm{H}), 7.44-7.21(\mathrm{~m}, 5 \mathrm{H}), 3.81-3.70(\mathrm{~m}, 1 \mathrm{H}), 3.64$ $-3.56(\mathrm{~m}, 1 \mathrm{H}), 3.54-3.46(\mathrm{~m}, 1 \mathrm{H}), 3.37-3.26(\mathrm{~m}, 1 \mathrm{H}), 3.25-3.05(\mathrm{~m}, 2 \mathrm{H}), 2.84(\mathrm{~s}$, $3 \mathrm{H}), 2.28(\mathrm{~d}, J=12.3 \mathrm{~Hz}, 1 \mathrm{H}), 1.82(\mathrm{q}, J=12.3 \mathrm{~Hz}, 1 \mathrm{H})$.

\section{3-methyl-2-\{[(3R,5R)-1-methyl-5-phenylpiperidin-3-yl]amino\}-3H,4H,5H-}

pyrrolo[3,2-d]pyrimidin-4-one ((R,R)-24a). A solution of $16(200 \mathrm{mg}, 1.09 \mathrm{mmol})$ in NMP was treated with $(R, R)-\mathbf{2 0 a}(344 \mathrm{mg}, 1.31 \mathrm{mmol})$ and DIPEA (183 mg, 1.42 mmol). Then the reaction was heated to $150{ }^{\circ} \mathrm{C}$ and stirred at this temperature for $2 \mathrm{~h}$. After cooling to ambient temperature, the mixture was diluted with EtOAc and water. The biphasic solution was extracted twice with EtOAc. The combined organics were washed with brine, dried over anhydrous $\mathrm{MgSO}_{4}$, and concentrated in vacuo. Purification of the residue by Biotage Isolera LPLC gave the title compound $(R, R)-\mathbf{2 4 a}$ (53 mg, $0.157 \mathrm{mmol}, 14 \%$ ) as a white solid. ${ }^{1} \mathrm{H}$ NMR (400 MHz, DMSO- $d_{6}$ ) $\delta 11.37$ (s, $1 \mathrm{H}), 7.36-7.13(\mathrm{~m}, 5 \mathrm{H}), 7.11(\mathrm{t}, J=2.9 \mathrm{~Hz}, 1 \mathrm{H}), 6.01(\mathrm{t}, J=2.5 \mathrm{~Hz}, 1 \mathrm{H}), 5.97(\mathrm{~d}, J=$ $7.7 \mathrm{~Hz}, 1 \mathrm{H}), 4.22-4.10(\mathrm{~m}, 1 \mathrm{H}), 3.31(\mathrm{~s}, 3 \mathrm{H}), 3.07$ (dd, $J=10.4,4.1 \mathrm{~Hz}, 1 \mathrm{H}), 2.92-$ 
$2.78(\mathrm{~m}, 2 \mathrm{H}), 2.20(\mathrm{~s}, 3 \mathrm{H}), 2.04(\mathrm{dd}, J=12.0,4.2 \mathrm{~Hz}, 1 \mathrm{H}), 1.91-1.75(\mathrm{~m}, 2 \mathrm{H}), 1.57$ $(\mathrm{q}, J=12.1 \mathrm{~Hz}, 1 \mathrm{H}) .{ }^{13} \mathrm{C} \mathrm{NMR}\left(101 \mathrm{MHz}, \mathrm{DMSO}-d_{6}\right) \delta 154.48,149.57,144.80,143.97$, $128.88,127.80,127.47,126.86,112.40,101.18,62.49,60.33,48.62,46.14,41.62$, 37.11, 27.72. HRMS $m / z 338.1985\left(\mathrm{M}+\mathrm{H}^{+}, \mathrm{C}_{21} \mathrm{H}_{25} \mathrm{~N}_{5} \mathrm{O}_{3}\right.$, requires 337.1903). Chiral HPLC (Chiralpak IE-H column, $4.6 \mathrm{~mm} \times 25 \mathrm{~cm}, 25 \% i$-PrOH/hexane, $1 \mathrm{~mL} / \mathrm{min}$ ): $\mathrm{R}_{\mathrm{t}}$ $=16.53 \mathrm{~min},>99 \%$ ee.

\section{3-methyl-2-\{[(3S,5S)-1-methyl-5-phenylpiperidin-3-yl]amino\}-3H,4H,5H-}

pyrrolo[3,2-d]pyrimidin-4-one $((S, S)-24 a)$. The title compound $(S, S)-24$ a was prepared in the same manner as shown for $(R, R)-\mathbf{2 4 a}$ except tert-butyl (3S)-3aminopiperidine-1-carboxylate $(S)$-17a was used instead. ${ }^{1} \mathrm{H}$ NMR (400 MHz, DMSO$\left.d_{6}\right) \delta 11.42(\mathrm{~s}, 1 \mathrm{H}), 7.36-7.19(\mathrm{~m}, 5 \mathrm{H}), 7.15(\mathrm{t}, J=2.9 \mathrm{~Hz}, 1 \mathrm{H}), 6.05(\mathrm{t}, J=2.5 \mathrm{~Hz}$, $1 \mathrm{H}), 6.00(\mathrm{~d}, J=7.7 \mathrm{~Hz}, 1 \mathrm{H}), 4.26-4.13(\mathrm{~m}, 1 \mathrm{H}), 3.36(\mathrm{~s}, 3 \mathrm{H}), 3.10(\mathrm{dd}, J=10.4,4.2$ $\mathrm{Hz}, 1 \mathrm{H}), 2.95-2.82(\mathrm{~m}, 2 \mathrm{H}), 2.23(\mathrm{~s}, 3 \mathrm{H}), 2.11-2.04(\mathrm{~m}, 1 \mathrm{H}), 1.93-1.76(\mathrm{~m}, 2 \mathrm{H})$, $1.62(\mathrm{q}, J=12.1 \mathrm{~Hz}, 1 \mathrm{H}) .{ }^{13} \mathrm{C}$ NMR $\left(101 \mathrm{MHz}, \mathrm{DMSO}-d_{6}\right) \delta 154.47,149.57,144.80$, $144.06,128.88,127.77,127.47,126.84,112.40,101.18,62.63,60.46,48.68,46.23$, 41.70, 37.16, 27.71. HRMS $m / z 338.1987\left(\mathrm{M}+\mathrm{H}^{+}, \mathrm{C}_{19} \mathrm{H}_{23} \mathrm{~N}_{5} \mathrm{O}\right.$, requires 337.1903). Chiral HPLC (Chiralpak IE-H column, $4.6 \mathrm{~mm} \times 25 \mathrm{~cm}, 25 \% i$-PrOH/hexane, 1 $\mathrm{mL} / \mathrm{min}): \mathrm{R}_{\mathrm{t}}=14.23 \mathrm{~min},>99 \%$ ee.

\section{3-methyl-2-[(cis-1-methyl-6-phenylazepan-4-yl)amino]-3H,4H,5H-}

pyrrolo[3,2-d]pyrimidin-4-one (cis-24b). The title compound cis-24b was prepared in the same manner as shown for $(R, R)$-24a except tert-butyl 4-aminoazepane-1carboxylate 17b was used instead. ${ }^{1} \mathrm{H}$ NMR $\left(400 \mathrm{MHz}, \mathrm{DMSO}-d_{6}\right) \delta 11.39$ (s, 1H), 7.31 
$-7.22(\mathrm{~m}, 4 \mathrm{H}), 7.19-7.10(\mathrm{~m}, 2 \mathrm{H}), 6.06(\mathrm{~d}, J=7.6 \mathrm{~Hz}, 1 \mathrm{H}), 6.02(\mathrm{t}, J=2.4 \mathrm{~Hz}, 1 \mathrm{H})$, $4.33-4.20(\mathrm{~m}, 1 \mathrm{H}), 3.35(\mathrm{~s}, 3 \mathrm{H}), 3.06-2.95(\mathrm{~m}, 1 \mathrm{H}), 2.73-2.62(\mathrm{~m}, 4 \mathrm{H}), 2.32(\mathrm{~s}$ $3 \mathrm{H}), 2.17-1.97(\mathrm{~m}, 3 \mathrm{H}), 1.90-1.77(\mathrm{~m}, 1 \mathrm{H}) .{ }^{13} \mathrm{C}$ NMR $\left(101 \mathrm{MHz}, \mathrm{DMSO}-d_{6}\right) \delta$ $154.52,149.35,147.02,144.93,128.83,127.65,127.29,126.40,112.31,101.21,65.54$ 53.85, 51.10, 47.36, 43.07, 42.07, 34.76, 27.62. HRMS $m / z 352.2137\left(\mathrm{M}+\mathrm{H}^{+}\right.$, $\mathrm{C}_{20} \mathrm{H}_{25} \mathrm{~N}_{5} \mathrm{O}$, requires 351.2059).

\section{3-methyl-2-\{[(1R,3r,5S)-9-methyl-9-azabicyclo[3.3.1]nonan-3-yl]amino\}-}

3H,4H,5H-pyrrolo[3,2-d]pyrimidin-4-one (endo-24c). Compound 16 (100 mg, 0.54 mmol), (1R,3r,5S)-9-methyl-9-azabicyclo[3.3.1]nonan-3-amine (100 mg, $0.65 \mathrm{mmol})$, and DIPEA (100 mg) were added to $4 \mathrm{~mL}$ NMP. The suspension was reacted at $150{ }^{\circ} \mathrm{C}$ for 2 hours. After cooling to ambient temperature, the mixture was diluted with EtOAc and water. The resulting solution was extracted twice with EtOAc. The combined organic layer was concentrated and purified by Biotage Isolera LPLC to give endo-24c (37 mg, $12.3 \mathrm{mmol}, 22.5 \%$ ) as a white solid. ${ }^{1} \mathrm{H}$ NMR (400 MHz, DMSO- $d_{6}$ ) $\delta 11.36$ (s, 1H), $7.13(\mathrm{t}, J=2.9 \mathrm{~Hz}, 1 \mathrm{H}), 6.03(\mathrm{t}, J=2.4 \mathrm{~Hz}, 1 \mathrm{H}), 5.84(\mathrm{~d}, J=8.5 \mathrm{~Hz}, 1 \mathrm{H}), 4.39$ (dtd, $J=14.4,12.0,6.5 \mathrm{~Hz}, 1 \mathrm{H}), 3.36(\mathrm{~s}, 3 \mathrm{H}), 2.97(\mathrm{~d}, J=11.1 \mathrm{~Hz}, 2 \mathrm{H}), 2.41(\mathrm{~s}, 3 \mathrm{H})$, $2.29(\mathrm{td}, J=12.1,6.2 \mathrm{~Hz}, 2 \mathrm{H}), 2.18-2.03(\mathrm{~m}, 1 \mathrm{H}), 1.92(\mathrm{tt}, J=13.4,4.3 \mathrm{~Hz}, 2 \mathrm{H}), 1.49$ $-1.37(\mathrm{~m}, 3 \mathrm{H}), 0.90(\mathrm{~d}, J=12.7 \mathrm{~Hz}, 2 \mathrm{H}) .{ }^{13} \mathrm{C} \mathrm{NMR}\left(101 \mathrm{MHz}, \mathrm{DMSO}-d_{6}\right) \delta 154.51$, $149.78,145.10,127.68,112.22,101.06,51.22,43.31,32.88,27.67,23.60,14.54$. HRMS $m / z 302.1981\left(\mathrm{M}+\mathrm{H}^{+}, \mathrm{C}_{16} \mathrm{H}_{23} \mathrm{~N}_{5} \mathrm{O}\right.$, requires 301.1903).

\section{2-\{[(1R,3R,5S)-8-benzyl-8-azabicyclo[3.2.1]octan-3-yl]amino\}-3-methyl-}

3H,4H,5H-pyrrolo[3,2-d]pyrimidin-4-one (endo-24d). The title compound endo-24d 
was prepared in the same manner as shown for endo-24c except commercial $(1 R, 3 R, 5 S)$-8-benzyl-8-azabicyclo[3.2.1] octan-3-amine was used instead. ${ }^{1} \mathrm{H}$ NMR $\left(400 \mathrm{MHz}, \mathrm{DMSO}-d_{6}\right) \delta 11.46(\mathrm{~s}, 1 \mathrm{H}), 7.42-7.20(\mathrm{~m}, 5 \mathrm{H}), 7.16(\mathrm{t}, J=2.9 \mathrm{~Hz}, 1 \mathrm{H})$, $6.06(\mathrm{t}, J=2.4 \mathrm{~Hz}, 1 \mathrm{H}), 5.56(\mathrm{~d}, J=2.9 \mathrm{~Hz}, 1 \mathrm{H}), 4.03(\mathrm{t}, J=6.6 \mathrm{~Hz}, 1 \mathrm{H}), 3.53(\mathrm{~s}, 2 \mathrm{H})$, $3.42(\mathrm{~s}, 3 \mathrm{H}), 3.12(\mathrm{~s}, 2 \mathrm{H}), 2.09-1.94(\mathrm{~m}, 6 \mathrm{H}), 1.89-1.80(\mathrm{~m}, 2 \mathrm{H}) .{ }^{13} \mathrm{C}$ NMR $(101$ $\left.\mathrm{MHz}, \mathrm{DMSO}-d_{6}\right) \delta 154.66,149.61,144.53,128.81,128.57,127.63,127.09,112.84$ 101.47, 58.15, 56.06, 43.69, 35.83, 27.76, 26.40. HRMS $m / z 364.2139\left(\mathrm{M}+\mathrm{H}^{+}\right.$, $\mathrm{C}_{21} \mathrm{H}_{25} \mathrm{~N}_{5} \mathrm{O}$, requires 363.2059).

\section{3-methyl-2-\{[(1R,3r,5S)-9-azabicyclo[3.3.1]nonan-3-yl]amino\}-3H,4H,5H-}

pyrrolo[3,2-d]pyrimidin-4-one $\quad($ endo-25a) and $3-$ methyl-2-\{[(1R,3s,5S)-9azabicyclo[3.3.1]nonan-3-yl]amino\}-3H,4H,5H-pyrrolo[3,2-d]pyrimidin-4-one

(exo-25a). Step 1. Endo-24e and exo-24e were prepared in the same manner as shown for endo-24c except commercial tert-butyl 3-amino-9-azabicyclo[3.3.1]nonane-9carboxylate (endo : exo $=2: 3 ; 3.14 \mathrm{~g}, 131 \mathrm{mmol}$ ) was used instead. The crude products were purified by Biotage Isolera LPLC to give endo-24e $(830 \mathrm{mg}, 2.14 \mathrm{mmol})$ and exo24e (1.2 g, $3.1 \mathrm{mmol})$ as white solids. endo-24e: ${ }^{1} \mathrm{H}$ NMR (400 MHz, DMSO- $\left.d_{6}\right) \delta$ $11.39(\mathrm{~s}, 1 \mathrm{H}), 7.14(\mathrm{t}, J=2.9 \mathrm{~Hz}, 1 \mathrm{H}), 6.03-5.91(\mathrm{~m}, 2 \mathrm{H}), 4.34(\mathrm{dd}, J=20.2,11.5 \mathrm{~Hz}$ 2H), $3.90-3.79(\mathrm{~m}, 1 \mathrm{H}), 3.35(\mathrm{~s}, 3 \mathrm{H}), 2.37-2.00(\mathrm{~m}, 4 \mathrm{H}), 1.57-1.33(\mathrm{~m}, 15 \mathrm{H})$. HRMS $m / z$ 388.2281 $\left(\mathrm{M}+\mathrm{H}^{+}, \mathrm{C}_{21} \mathrm{H}_{25} \mathrm{~N}_{5} \mathrm{O}_{3}\right.$, requires 387.2270). Chiral HPLC (Chiralpak IE-H column, $4.6 \mathrm{~mm} \times 25 \mathrm{~cm}, 20 \% i-\mathrm{PrOH} / \mathrm{hexane}, 1 \mathrm{~mL} / \mathrm{min}$ ): $\mathrm{R}_{\mathrm{t}}=17.14$ $\min ,>99 \%$ ee. exo-24e: ${ }^{1} \mathrm{H}$ NMR (400 MHz, DMSO-d $) \delta 11.40(\mathrm{~s}, 1 \mathrm{H}), 7.14(\mathrm{t}, J=$ $2.9 \mathrm{~Hz}, 1 \mathrm{H}), 6.01(\mathrm{t}, J=2.4 \mathrm{~Hz}, 1 \mathrm{H}), 5.86(\mathrm{~d}, J=7.9 \mathrm{~Hz}, 1 \mathrm{H}), 4.97-4.84(\mathrm{~m}, 1 \mathrm{H}), 4.23$ 
$(\mathrm{d}, J=16.3 \mathrm{~Hz}, 2 \mathrm{H}), 3.33(\mathrm{~s}, 3 \mathrm{H}), 2.06-1.86(\mathrm{~m}, 3 \mathrm{H}), 1.75-1.62(\mathrm{~m}, 6 \mathrm{H}), 1.42(\mathrm{~s}$, 9H). ${ }^{13} \mathrm{C}$ NMR $\left(101 \mathrm{MHz}, \mathrm{DMSO}-d_{6}\right) \delta 154.47,153.38,149.62,144.85,127.70,112.34$, $101.27,78.78,47.68,46.08,44.96,36.78,36.36,29.44,28.69,27.68$. HRMS $m / z$ 388.2237 $\left(\mathrm{M}+\mathrm{H}^{+}, \mathrm{C}_{21} \mathrm{H}_{25} \mathrm{~N}_{5} \mathrm{O}_{3}\right.$, requires 387.2270). Chiral HPLC (Chiralpak IE-H column, $4.6 \mathrm{~mm} \times 25 \mathrm{~cm}, 20 \% i-\mathrm{PrOH} /$ hexane, $1 \mathrm{~mL} / \mathrm{min}$ ): $\mathrm{R}_{\mathrm{t}}=14.37 \mathrm{~min},>99 \%$ ee.

Step 2. To a stirred solution of endo-24e in DCM at room temperature was added trifluoroacetic acid. After reaction completion, the solvent was removed under reduced pressure and the residue was basified and purified to give endo-25a as white solid. endo-25a: ${ }^{1} \mathrm{H}$ NMR (400 MHz, DMSO-d $\left.d_{6}\right) \delta 11.41(\mathrm{~s}, 1 \mathrm{H}), 7.15(\mathrm{~d}, J=2.8 \mathrm{~Hz}, 1 \mathrm{H})$, $6.02(\mathrm{~d}, J=2.8 \mathrm{~Hz}, 1 \mathrm{H}), 5.84(\mathrm{~d}, J=8.2 \mathrm{~Hz}, 1 \mathrm{H}), 4.28-4.12(\mathrm{~m}, 1 \mathrm{H}), 3.37(\mathrm{~s}, 3 \mathrm{H})$, $3.29-3.23(\mathrm{~m}, 2 \mathrm{H}), 2.19(\mathrm{td}, J=11.7,5.9 \mathrm{~Hz}, 2 \mathrm{H}), 2.10-1.97(\mathrm{~m}, 1 \mathrm{H}), 1.56(\mathrm{tt}, J=$ 12.8, 4.2 Hz, 2H), $1.50-1.41(\mathrm{~m}, 1 \mathrm{H}), 1.39-1.25(\mathrm{~m}, 4 \mathrm{H}) .{ }^{13} \mathrm{C}$ NMR (101 MHz, DMSO- $\left.d_{6}\right) \delta 154.51,149.66,145.00,127.69,112.30,101.02,45.23,43.68,32.69$, 32.23, 27.70, 14.54. HRMS $m / z 288.1827\left(\mathrm{M}+\mathrm{H}^{+}, \mathrm{C}_{21} \mathrm{H}_{25} \mathrm{~N}_{5} \mathrm{O}_{3}\right.$, requires 287.1746). exo-25a was prepared from exo-24e using the procedure described for compound endo25a as a white solid. exo-25a: ${ }^{1} \mathrm{H}$ NMR (400 MHz, DMSO-d $\left.{ }_{6}\right) \delta 11.40(\mathrm{~s}, 1 \mathrm{H}), 7.14(\mathrm{~d}$, $J=2.8 \mathrm{~Hz}, 1 \mathrm{H}), 6.00(\mathrm{~d}, J=2.8 \mathrm{~Hz}, 1 \mathrm{H}), 5.81(\mathrm{~d}, J=7.7 \mathrm{~Hz}, 1 \mathrm{H}), 4.82(\mathrm{tq}, J=12.2$, $6.4 \mathrm{~Hz}, 1 \mathrm{H}), 3.35(\mathrm{~s}, 3 \mathrm{H}), 3.18-3.13(\mathrm{~m}, 2 \mathrm{H}), 2.05-1.86(\mathrm{~m}, 3 \mathrm{H}), 1.85-1.60(\mathrm{~m}$, 7H). ${ }^{13} \mathrm{C}$ NMR (101 MHz, DMSO-d 6 ) $\delta 154.52,149.66,144.96,127.67,112.31,101.24$, 47.31, 45.40, 38.01, 30.43, 27.67, 21.03. HRMS $m / z 288.1819\left(\mathrm{M}+\mathrm{H}^{+}, \mathrm{C}_{21} \mathrm{H}_{25} \mathrm{~N}_{5} \mathrm{O}_{3}\right.$, requires 287.1746$)$. 


\section{3-methyl-2-\{[(1R,3r,5S)-9-[(2R)-2-hydroxy-2-phenylethyl]-9-}

\section{azabicyclo[3.3.1]nonan-3-yl]amino\}-3H,4H,5H-pyrrolo[3,2-d]pyrimidin-4-one}

(endo-26a). To a stirred solution of endo-25a (100 $\mathrm{mg}, 0.35 \mathrm{mmol})$ and triethylamine (61 mg, $0.6 \mathrm{mmol})$ in $\mathrm{MeCN}$ was added $(R)$-2-phenyloxirane (60 mg, $0.5 \mathrm{mmol})$. The mixture was reacted at $70{ }^{\circ} \mathrm{C}$ overnight. After cooling to room temperature, the mixture was concentrated under reduced pressure and the residue was purified by Biotage Isolera LPLC to give endo-26a in 58\% yield as a white solid. ${ }^{1} \mathrm{H}$ NMR (400 MHz, DMSO-d6) $\delta 11.38(\mathrm{~s}, 1 \mathrm{H}), 7.44-7.29(\mathrm{~m}, 4 \mathrm{H}), 7.27-7.20(\mathrm{~m}, 1 \mathrm{H}), 7.15(\mathrm{t}, J=2.9$ $\mathrm{Hz}, 1 \mathrm{H}), 6.05(\mathrm{t}, J=2.4 \mathrm{~Hz}, 1 \mathrm{H}), 5.81(\mathrm{~d}, J=8.3 \mathrm{~Hz}, 1 \mathrm{H}), 4.89(\mathrm{~s}, 1 \mathrm{H}), 4.57$ (dd, $J=$ 7.8, $5.1 \mathrm{~Hz}, 1 \mathrm{H}), 4.42-4.27(\mathrm{~m}, 1 \mathrm{H}), 3.37(\mathrm{~s}, 3 \mathrm{H}), 3.14-2.96(\mathrm{~m}, 2 \mathrm{H}), 2.79(\mathrm{dd}, J=$ 13.1, 5.1 Hz, 1H), $2.68(\mathrm{dd}, J=13.0,7.8 \mathrm{~Hz}, 1 \mathrm{H}), 2.40-2.19(\mathrm{~m}, 2 \mathrm{H}), 2.16-2.00(\mathrm{~m}$, 1H), $1.89-1.63(\mathrm{~m}, 2 \mathrm{H}), 1.49-1.31(\mathrm{~m}, 3 \mathrm{H}), 1.08-0.94(\mathrm{~m}, 2 \mathrm{H}) .{ }^{13} \mathrm{C}$ NMR $(101$ MHz, DMSO-d $d_{6} \delta 154.53,149.73,145.05,128.24,127.73,127.14,126.57,112.28$, 101.11, 71.39, 61.31, 51.48, 49.95, 43.34, 32.34, 27.71, 26.78, 26.33, 14.22. HRMS $m / z 408.2405\left(\mathrm{M}+\mathrm{H}^{+}, \mathrm{C}_{23} \mathrm{H}_{29} \mathrm{~N}_{5} \mathrm{O}_{2}\right.$, requires 407.2321).

\section{3-methyl-2-\{[(1R,3r,5S)-9-[(2S)-2-hydroxy-2-(pyridin-2-yl)ethyl]-9-}

\section{azabicyclo[3.3.1]nonan-3-yl]amino\}-3H,4H,5H-pyrrolo[3,2-d]pyrimidin-4-one}

(endo-26b). The title compound was prepared from endo-25a (100 mg, $0.75 \mathrm{mmol})$ and (R)-2-bromo-1-(pyridin-2-yl)ethan-1-ol ( $162 \mathrm{mg}, 0.8 \mathrm{mmol}$ ) using the procedure described for compound endo-26a in 47\% yield as a white solid. ${ }^{1} \mathrm{H}$ NMR (400 MHz, DMSO-d $)_{6} \delta 11.38(\mathrm{~s}, 1 \mathrm{H}), 8.57-8.43(\mathrm{~m}, 1 \mathrm{H}), 7.79(\mathrm{td}, J=7.7,1.9 \mathrm{~Hz}, 1 \mathrm{H}), 7.53(\mathrm{~d}$, $J=7.8 \mathrm{~Hz}, 1 \mathrm{H}), 7.25(\mathrm{dd}, J=7.4,4.9 \mathrm{~Hz}, 1 \mathrm{H}), 7.15(\mathrm{t}, J=2.9 \mathrm{~Hz}, 1 \mathrm{H}), 6.07$ (t, $J=2.4$ 
$\mathrm{Hz}, 1 \mathrm{H}), 5.80(\mathrm{~d}, J=8.3 \mathrm{~Hz}, 1 \mathrm{H}), 5.10(\mathrm{~s}, 1 \mathrm{H}), 4.62(\mathrm{dd}, J=7.9,4.1 \mathrm{~Hz}, 1 \mathrm{H}), 4.39-$ $4.26(\mathrm{~m}, 1 \mathrm{H}), 3.37(\mathrm{~s}, 3 \mathrm{H}), 3.13-2.96(\mathrm{~m}, 3 \mathrm{H}), 2.70(\mathrm{dd}, J=13.1,7.9 \mathrm{~Hz}, 1 \mathrm{H}), 2.29$ $(\mathrm{dp}, J=16.2,5.1 \mathrm{~Hz}, 2 \mathrm{H}), 2.15-2.01(\mathrm{~m}, 1 \mathrm{H}), 1.86-1.67(\mathrm{~m}, 2 \mathrm{H}), 1.47-1.33(\mathrm{~m}$, 3H), $1.00(\mathrm{~d}, J=12.8 \mathrm{~Hz}, 2 \mathrm{H}) \cdot{ }^{13} \mathrm{C}$ NMR (101 MHz, DMSO-d $) \delta 163.80,154.53$, $149.72,148.66,145.03,136.80,127.73,122.45,121.03,112.26,101.12,72.86,59.56$, 51.48, 49.98, 43.31, 32.38, 27.71, 26.71, 26.28, 14.22. HRMS $m / z$ 409.2359 (M + $\mathrm{H}^{+}$, $\mathrm{C}_{22} \mathrm{H}_{28} \mathrm{~N}_{6} \mathrm{O}_{2}$, requires 408.2274).

2-chloro-3-ethyl-3H,4H,5H-pyrrolo[3,2-d]pyrimidin-4-one (27a). 27a was prepared from $15(2.0 \mathrm{~g}, 7.42 \mathrm{mmol})$ and iodoethane $(1.5 \mathrm{~g}, 9.65 \mathrm{mmol})$ using the procedure described for 16 in 51\% yield as a white solid. ${ }^{1} \mathrm{H}$ NMR (400 MHz, DMSO$\left.d_{6}\right) \delta 12.29(\mathrm{~s}, 1 \mathrm{H}), 7.43(\mathrm{t}, J=2.9 \mathrm{~Hz}, 1 \mathrm{H}), 6.35(\mathrm{dd}, J=2.9,2.0 \mathrm{~Hz}, 1 \mathrm{H}), 4.24(\mathrm{q}, J=$ $7.1 \mathrm{~Hz}, 2 \mathrm{H}), 1.26(\mathrm{t}, J=7.1 \mathrm{~Hz}, 3 \mathrm{H})$.

2-chloro-3-(prop-2-en-1-yl)-3H,4H,5H-pyrrolo[3,2-d]pyrimidin-4-one (27b). 27b was prepared from 15 (2.0 g, $7.42 \mathrm{mmol})$ and 3-bromoprop-1-ene (1.17 g, 9.65 mmol) using the procedure described for $\mathbf{1 6}$ in $49 \%$ yield as a white solid. ${ }^{1} \mathrm{H}$ NMR (400 MHz, DMSO- $\left.d_{6}\right) \delta 12.33(\mathrm{~s}, 1 \mathrm{H}), 7.46(\mathrm{t}, J=2.9 \mathrm{~Hz}, 1 \mathrm{H}), 6.38(\mathrm{t}, J=2.4 \mathrm{~Hz}, 1 \mathrm{H})$, $6.02-5.90(\mathrm{~m}, 1 \mathrm{H}), 5.20(\mathrm{dq}, J=10.5,1.6 \mathrm{~Hz}, 1 \mathrm{H}), 5.02(\mathrm{dq}, J=17.1,1.7 \mathrm{~Hz}, 1 \mathrm{H})$, $4.83(\mathrm{dt}, J=4.9,1.8 \mathrm{~Hz}, 2 \mathrm{H})$.

\section{3-(but-3-en-1-yl)-2-chloro-3H,4H,5H-pyrrolo[3,2-d]pyrimidin-4-one (27c).}

27c was prepared from 15 (2.0 g, $7.42 \mathrm{mmol})$ and 4-bromobut-1-ene (1.30 g, $9.65 \mathrm{mmol})$ using the procedure described for 16 in $34 \%$ yield as a white solid. ${ }^{1} \mathrm{H}$ NMR (400 MHz, 
DMSO- $\left.d_{6}\right) \delta 12.29(\mathrm{~s}, 1 \mathrm{H}), 7.44(\mathrm{t}, J=2.9 \mathrm{~Hz}, 1 \mathrm{H}), 6.35(\mathrm{dd}, J=2.9,2.0 \mathrm{~Hz}, 1 \mathrm{H}), 5.90$ $-5.80(\mathrm{~m}, 1 \mathrm{H}), 5.09-5.00(\mathrm{~m}, 2 \mathrm{H}), 4.32-4.22(\mathrm{~m}, 2 \mathrm{H}), 2.45(\mathrm{q}, J=7.1 \mathrm{~Hz}, 2 \mathrm{H})$.

3-(but-2-en-1-yl)-2-chloro-3H,4H,5H-pyrrolo[3,2-d]pyrimidin-4-one (27d). 27d was prepared from $15(2.0 \mathrm{~g}, 7.42 \mathrm{mmol})$ and 1-bromobut-2-ene (1.30 g, $9.65 \mathrm{mmol})$ using the procedure described for 16 in $39 \%$ yield as a white solid. ${ }^{1} \mathrm{H}$ NMR (400 MHz, DMSO- $\left.d_{6}\right) \delta 12.31(\mathrm{~s}, 1 \mathrm{H}), 7.45(\mathrm{t}, J=3.0 \mathrm{~Hz}, 1 \mathrm{H}), 6.36(\mathrm{dd}, J=2.8,2.0 \mathrm{~Hz}, 1 \mathrm{H}), 5.64$ $-5.52(\mathrm{~m}, 2 \mathrm{H}), 4.81-4.70(\mathrm{~m}, 2 \mathrm{H}), 1.80-1.72(\mathrm{~m}, 1 \mathrm{H}), 1.68-1.62(\mathrm{~m}, 2 \mathrm{H})$.

2-chloro-3,5-dimethyl-3H,4H,5H-pyrrolo[3,2-d]pyrimidin-4-one (28). $\mathrm{NaH}$ (60\% in mineral oil, $400 \mathrm{mg}, 10.0 \mathrm{mmol}$ ) was added portionwise to a stirred solution of $14(1.2 \mathrm{~g}, 7.08 \mathrm{mmol})$ in anhydrous DMF $(30 \mathrm{~mL})$ at $0{ }^{\circ} \mathrm{C}$. Twenty minutes later, iodomethane $(2.27 \mathrm{~g}, 16.0 \mathrm{mmol})$ was added. The mixture was reacted at $60{ }^{\circ} \mathrm{C}$ for $5 \mathrm{~h}$. After cooling to rt, the reaction mixture was diluted with water and extracted with EtOAc. The combined organic phase was concentrated under reduced pressure and the residue was purified by Biotage Isolera LPLC (PE/EA 10:1- 2:1) to give 28 (1.09 g, $78 \%$ ) as a white solid. ${ }^{1} \mathrm{H}$ NMR (400 MHz, DMSO- $\left.d_{6}\right) \delta 7.43(\mathrm{~d}, J=2.9 \mathrm{~Hz}, 1 \mathrm{H}), 6.30$ $(\mathrm{d}, J=2.9 \mathrm{~Hz}, 1 \mathrm{H}), 3.98(\mathrm{~s}, 3 \mathrm{H}), 3.58(\mathrm{~s}, 3 \mathrm{H})$.

2-chloro-3-methyl-3H,4H-thieno[3,2-d]pyrimidin-4-one (31). Step 1. 2-chloro3H,4H-thieno[3,2-d]pyrimidin-4-one 30 (1.73 g, $9.27 \mathrm{mmol}, 95 \%)$ was prepared from $29(2.0 \mathrm{~g}, 9.75 \mathrm{mmol})$ using the procedure described for $\mathbf{1 4}$ as a yellow solid.

Step 2. 31 (1.43 g, 77\%) was prepared from $30(1.73 \mathrm{~g}, 9.27 \mathrm{mmol})$ and iodomethane (1.8 g, $12.7 \mathrm{mmol})$ using the procedure described for $\mathbf{2 8}$ as a yellow solid. 
${ }^{1} \mathrm{H}$ NMR (400 MHz, DMSO-d $)_{6} \delta 8.24(\mathrm{~d}, J=5.2 \mathrm{~Hz}, 1 \mathrm{H}), 7.37(\mathrm{~d}, J=5.2 \mathrm{~Hz}, 1 \mathrm{H})$, $3.64(\mathrm{~s}, 3 \mathrm{H})$.

\section{3-ethyl-2-\{[(3R,5R)-1-methyl-5-phenylpiperidin-3-yl]amino\}-3H,4H,5H-}

pyrrolo[3,2-d]pyrimidin-4-one $((\boldsymbol{R}, \boldsymbol{R})-32 \mathrm{a})$. The title compound was prepared from 27a $(180 \mathrm{mg}, 0.91 \mathrm{mmol})$ and $(R, R)-20 a(264 \mathrm{mg}, 1.0 \mathrm{mmol})$ using the procedure described for compound $(R, R)-\mathbf{2 4 a}$ in $13 \%$ yield as a white solid. ${ }^{1} \mathrm{H}$ NMR (400 MHz, DMSO-d $d_{6} \delta 11.40(\mathrm{~s}, 1 \mathrm{H}), 7.36-7.19(\mathrm{~m}, 5 \mathrm{H}), 7.15(\mathrm{t}, J=2.9 \mathrm{~Hz}, 1 \mathrm{H}), 6.09-6.01$ $(\mathrm{m}, 2 \mathrm{H}), 4.25(\mathrm{dtt}, J=11.5,7.5,4.0 \mathrm{~Hz}, 1 \mathrm{H}), 4.07(\mathrm{q}, J=7.0 \mathrm{~Hz}, 2 \mathrm{H}), 3.09(\mathrm{dd}, J=$ 10.5, 4.1 Hz, 1H), $2.96-2.83(\mathrm{~m}, 2 \mathrm{H}), 2.24(\mathrm{~s}, 3 \mathrm{H}), 2.03(\mathrm{dd}, J=10.0,6.1 \mathrm{~Hz}, 1 \mathrm{H})$, $1.94-1.77(\mathrm{~m}, 2 \mathrm{H}), 1.65(\mathrm{q}, J=12.1 \mathrm{~Hz}, 1 \mathrm{H}), 1.12(\mathrm{t}, J=7.0 \mathrm{~Hz}, 3 \mathrm{H}) .{ }^{13} \mathrm{C}$ NMR $(101$ MHz, DMSO-d6) $\delta 154.30,148.65,144.82,144.09,128.87,127.77,127.48,126.84$ $112.57,101.13,62.53,60.43,48.56,46.22,41.75,37.19,34.90,13.73$. HRMS $m / z$ 352.2136 $\left(\mathrm{M}+\mathrm{H}^{+}, \mathrm{C}_{20} \mathrm{H}_{25} \mathrm{~N}_{5} \mathrm{O}\right.$, requires 351.2059).

\section{2-\{[(3R,5R)-1-methyl-5-phenylpiperidin-3-yl]amino\}-3-(prop-2-en-1-yl)-}

3H,4H,5H-pyrrolo[3,2-d]pyrimidin-4-one $((\boldsymbol{R}, \boldsymbol{R})-32 \mathrm{~b})$. The title compound was prepared from 27b $(190 \mathrm{mg}, 0.91 \mathrm{mmol})$ and $(R, R)-\mathbf{2 0 a}(264 \mathrm{mg}, 1.0 \mathrm{mmol})$ using the procedure described for compound $(R, R)-\mathbf{2 4 a}$ in $17 \%$ yield as a white solid. ${ }^{1} \mathrm{H}$ NMR $\left(400 \mathrm{MHz}, \mathrm{DMSO}-d_{6}\right) \delta 11.46(\mathrm{~s}, 1 \mathrm{H}), 7.34-7.16(\mathrm{~m}, 6 \mathrm{H}), 6.06(\mathrm{t}, J=2.4 \mathrm{~Hz}, 1 \mathrm{H})$, $5.91-5.80(\mathrm{~m}, 1 \mathrm{H}), 5.76(\mathrm{~d}, J=7.8 \mathrm{~Hz}, 1 \mathrm{H}), 5.12-5.05(\mathrm{~m}, 1 \mathrm{H}), 5.01-4.93(\mathrm{~m}, 1 \mathrm{H})$, $4.71(\mathrm{~d}, J=4.8 \mathrm{~Hz}, 2 \mathrm{H}), 4.21(\mathrm{dd}, J=7.2,3.7 \mathrm{~Hz}, 1 \mathrm{H}), 3.06(\mathrm{dd}, J=10.6,4.3 \mathrm{~Hz}, 1 \mathrm{H})$, $2.95-2.81(\mathrm{~m}, 2 \mathrm{H}), 2.23(\mathrm{~s}, 3 \mathrm{H}), 2.01(\mathrm{~d}, J=12.3 \mathrm{~Hz}, 1 \mathrm{H}), 1.89(\mathrm{t}, J=10.8 \mathrm{~Hz}, 1 \mathrm{H})$, $1.76(\mathrm{t}, J=10.5 \mathrm{~Hz}, 1 \mathrm{H}), 1.56(\mathrm{q}, J=12.1 \mathrm{~Hz}, 1 \mathrm{H}) \cdot{ }^{13} \mathrm{C}$ NMR $\left(101 \mathrm{MHz}, \mathrm{DMSO}-d_{6}\right) \delta$ 
$154.19,148.76,144.99,144.04,133.40,128.87,128.01,127.47,126.84,115.94$ $112.31,101.25,62.45,60.39,48.62,46.20,46.17,41.68,41.52,37.29$. HRMS $m / z$ 364.2133 $\left(\mathrm{M}+\mathrm{H}^{+}, \mathrm{C}_{21} \mathrm{H}_{25} \mathrm{~N}_{5} \mathrm{O}\right.$, requires 363.2059).

\section{3-(but-3-en-1-yl)-2-\{[(3R,5R)-1-methyl-5-phenylpiperidin-3-yl]amino\}-}

3H,4H,5H-pyrrolo[3,2-d]pyrimidin-4-one $((\boldsymbol{R}, \boldsymbol{R})-32 \mathrm{c})$. The title compound was prepared from 27c (180 $\mathrm{mg}, 0.8 \mathrm{mmol})$ and $(R, R)-\mathbf{2 0 a}(233 \mathrm{mg}, 0.88 \mathrm{mmol})$ using the procedure described for compound $(R, R)-\mathbf{2 4 a}$ in $19 \%$ yield as a white solid. ${ }^{1} \mathrm{H}$ NMR (400 MHz, DMSO-d6) $\delta 11.38(\mathrm{~s}, 1 \mathrm{H}), 7.36-7.26(\mathrm{~m}, 4 \mathrm{H}), 7.26-7.18(\mathrm{~m}, 1 \mathrm{H}), 7.15$ $(\mathrm{t}, J=2.9 \mathrm{~Hz}, 1 \mathrm{H}), 6.08-5.99(\mathrm{~m}, 2 \mathrm{H}), 5.82(\mathrm{ddt}, J=17.0,10.2,6.7 \mathrm{~Hz}, 1 \mathrm{H}), 5.05-$ $4.93(\mathrm{~m}, 2 \mathrm{H}), 4.24(\mathrm{td}, J=11.4,9.4,5.2 \mathrm{~Hz}, 1 \mathrm{H}), 4.13(\mathrm{dd}, J=8.4,6.3 \mathrm{~Hz}, 2 \mathrm{H}), 3.12-$ $3.04(\mathrm{~m}, 1 \mathrm{H}), 2.97-2.79(\mathrm{~m}, 2 \mathrm{H}), 2.32(\mathrm{q}, J=7.1 \mathrm{~Hz}, 2 \mathrm{H}), 2.24(\mathrm{~s}, 3 \mathrm{H}), 2.04(\mathrm{dd}, J=$ 10.0, $6.1 \mathrm{~Hz}, 1 \mathrm{H}), 1.93-1.78(\mathrm{~m}, 2 \mathrm{H}), 1.63(\mathrm{q}, J=12.1 \mathrm{~Hz}, 1 \mathrm{H}) .{ }^{13} \mathrm{C} \mathrm{NMR}(101 \mathrm{MHz}$, DMSO- $\left.d_{6}\right) \delta 154.49,148.74,144.76,144.09,135.68,128.88,127.81,127.48,126.84$ 117.24, 112.52, 101.17, 62.50, 60.39, 48.63, 46.22, 41.75, 38.76, 37.23, 32.27. HRMS $m / z 378.2293\left(\mathrm{M}+\mathrm{H}^{+}, \mathrm{C}_{22} \mathrm{H}_{27} \mathrm{~N}_{5} \mathrm{O}\right.$, requires 377.2216).

\section{3-[(2E/Z)-but-2-en-1-yl]-2-\{[(3R,5R)-1-methyl-5-phenylpiperidin-3-}

yl]amino\}-3H,4H,5H-pyrrolo[3,2-d]pyrimidin-4-one $\quad((R, R)-32 d) . \quad$ The title compound was prepared from $\mathbf{2 7 d}(180 \mathrm{mg}, 0.8 \mathrm{mmol})$ and $(R, R)-\mathbf{2 0 a}(233 \mathrm{mg}, 0.88$ mmol) using the procedure described for compound $(R, R)$-24a in 14\% yield as a white solid. ${ }^{1} \mathrm{H}$ NMR (400 MHz, DMSO- $\left.d_{6}\right) \delta 11.42(\mathrm{~s}, 1 \mathrm{H}), 7.36-7.19(\mathrm{~m}, 5 \mathrm{H}), 7.16(\mathrm{t}, J=$ $2.9 \mathrm{~Hz}, 1 \mathrm{H}), 6.05(\mathrm{t}, J=2.4 \mathrm{~Hz}, 1 \mathrm{H}), 5.76(\mathrm{~d}, J=7.8 \mathrm{~Hz}, 1 \mathrm{H}), 5.59-5.40(\mathrm{~m}, 2 \mathrm{H}), 4.62$ $(\mathrm{d}, J=4.9 \mathrm{~Hz}, 2 \mathrm{H}), 4.24-4.12(\mathrm{~m}, 1 \mathrm{H}), 3.06(\mathrm{dd}, 1 \mathrm{H}), 2.93-2.82(\mathrm{~m}, 2 \mathrm{H}), 2.24(\mathrm{~s}$, 
3H), $2.02(\mathrm{dt}, J=12.4,3.9 \mathrm{~Hz}, 1 \mathrm{H}), 1.95-1.87(\mathrm{~m}, 1 \mathrm{H}), 1.76(\mathrm{t}, 1 \mathrm{H}), 1.65-1.50(\mathrm{~m}$, 4H). ${ }^{13} \mathrm{C}$ NMR (101 MHz, DMSO- $\left.d_{6}\right) \delta 154.20,148.77,144.87,144.02,128.89,127.94$, $127.69,127.48,126.86,125.86,112.44,101.20,62.43,60.40,48.61,46.18,41.65$, 40.82, 37.25, 17.86. HRMS $m / z$ 378.2295 $\left(\mathrm{M}+\mathrm{H}^{+}, \mathrm{C}_{22} \mathrm{H}_{27} \mathrm{~N}_{5} \mathrm{O}\right.$, requires 377.2216).

\section{3,5-dimethyl-2-\{[(3R,5R)-1-methyl-5-phenylpiperidin-3-yl]amino\}-}

3H,4H,5H-pyrrolo[3,2-d]pyrimidin-4-one $((\boldsymbol{R}, \boldsymbol{R})-32 \mathrm{e})$. The title compound was prepared from $28(150 \mathrm{mg}, 0.76 \mathrm{mmol})$ and $(R, R)$-20a $(224 \mathrm{mg}, 0.85 \mathrm{mmol})$ using the procedure described for compound $(R, R)-\mathbf{2 4 a}$ in $23 \%$ yield as a white solid. ${ }^{1} \mathrm{H}$ NMR (400 MHz, DMSO-d6) $\delta 7.36-7.19(\mathrm{~m}, 5 \mathrm{H}), 7.15(\mathrm{~d}, J=2.8 \mathrm{~Hz}, 1 \mathrm{H}), 6.03(\mathrm{~d}, J=7.8$ Hz, 1H), 5.99 (d, J=2.8 Hz, 1H), $4.24-4.13(\mathrm{~m}, 1 \mathrm{H}), 3.88(\mathrm{~s}, 3 \mathrm{H}), 3.33(\mathrm{~s}, 3 \mathrm{H}), 3.09$ $(\mathrm{dd}, J=10.4,4.1 \mathrm{~Hz}, 1 \mathrm{H}), 2.97-2.80(\mathrm{~m}, 2 \mathrm{H}), 2.23(\mathrm{~s}, 3 \mathrm{H}), 2.07(\mathrm{dd}, J=11.5,4.2 \mathrm{~Hz}$, 1H), $1.85(\mathrm{dt}, J=27.9,10.6 \mathrm{~Hz}, 2 \mathrm{H}), 1.62(\mathrm{q}, J=12.1 \mathrm{~Hz}, 1 \mathrm{H}) .{ }^{13} \mathrm{C}$ NMR $(101 \mathrm{MHz}$, DMSO- $\left.d_{6}\right) \delta 154.90,149.66,145.21,144.04,132.37,128.87,127.47,126.84,112.17$, $100.02,62.60,60.42,48.62,46.21,41.68,37.13,35.56,27.45$. HRMS $m / z 352.2136$ $\left(\mathrm{M}+\mathrm{H}^{+}, \mathrm{C}_{20} \mathrm{H}_{25} \mathrm{~N}_{5} \mathrm{O}\right.$, requires 351.2059).

\section{3-methyl-2-\{[(3R,5R)-1-methyl-5-phenylpiperidin-3-yl]amino $\}-3 \mathrm{H}, 4 \mathrm{H}-$}

thieno[3,2-d]pyrimidin-4-one $((\boldsymbol{R}, \boldsymbol{R})-\mathbf{3 2 f})$. The title compound was prepared from $\mathbf{3 1}$ (150 mg, $0.75 \mathrm{mmol})$ and $(R, R)-\mathbf{2 0 a}(211 \mathrm{mg}, 0.8 \mathrm{mmol})$ using the procedure described for compound $(R, R)-\mathbf{2 4 a}$ in $47 \%$ yield as a white solid. ${ }^{1} \mathrm{H}$ NMR (400 MHz, DMSO- $d_{6}$ ) $\delta 7.96(\mathrm{~d}, J=5.3 \mathrm{~Hz}, 1 \mathrm{H}), 7.38-7.26(\mathrm{~m}, 4 \mathrm{H}), 7.25-7.20(\mathrm{~m}, 1 \mathrm{H}), 7.10(\mathrm{~d}, J=5.3$ $\mathrm{Hz}, 1 \mathrm{H}), 6.60$ (d, $J=7.9 \mathrm{~Hz}, 1 \mathrm{H}), 4.30$ (ddd, $J=18.5,9.7,6.3 \mathrm{~Hz}, 1 \mathrm{H}), 3.40$ (s, 3H), $3.08(\mathrm{dd}, J=10.5,4.2 \mathrm{~Hz}, 1 \mathrm{H}), 2.98-2.81(\mathrm{~m}, 2 \mathrm{H}), 2.24(\mathrm{~s}, 3 \mathrm{H}), 2.07(\mathrm{dt}, J=12.1,3.8$ 
$\mathrm{Hz}, 1 \mathrm{H}), 1.88(\mathrm{q}, J=10.6 \mathrm{~Hz}, 2 \mathrm{H}), 1.69(\mathrm{q}, J=12.1 \mathrm{~Hz}, 1 \mathrm{H}) .{ }^{13} \mathrm{C}$ NMR $(101 \mathrm{MHz}$ DMSO-d $d_{6} \delta 158.20,157.96,152.92,143.91,134.95,128.88,127.46,126.87,124.49$, $112.10,62.48,60.12,48.90,46.18,41.63,36.89,28.16$. HRMS $m / z 355.1560\left(\mathrm{M}+\mathrm{H}^{+}\right.$, $\mathrm{C}_{19} \mathrm{H}_{22} \mathrm{~N}_{4} \mathrm{OS}$, requires 354.1514).

tert-butyl (3R,5R)-3-(2,3-dihydro-1,4-benzodioxin-6-yl)-5-(pyridine-2amido)piperidine-1-carboxylate $((\boldsymbol{R}, \boldsymbol{R})-33 \mathbf{j})$. A pressure vial $(100 \mathrm{~mL})$ equipped with a magnetic stirring bar was charged with compound $(R)-\mathbf{1 8 a}(2.5 \mathrm{~g}, 8.19 \mathrm{mmol})$, silver carbonate (2.26 g, $8.19 \mathrm{mmol}), \mathrm{Pd}(\mathrm{OAc})_{2}(184 \mathrm{mg}, 0.82 \mathrm{mmol})$, 6-iodo-2,3-dihydro1,4-benzodioxine (5.0 g, $19.1 \mathrm{mmol})$, 2,6-dimethylbenzoic acid (307 mg, $2.05 \mathrm{mmol})$, and $30 \mathrm{~mL} t-\mathrm{BuOH}$. The vessel was flushed with argon, sealed with a crimp cap and heated to $120^{\circ} \mathrm{C}$. After $24 \mathrm{~h}$, the reaction vessel was removed from the oil bath, cooled to room temperature, and DCM $(50 \mathrm{~mL})$ was added to the reaction mixture. The mixture was thoroughly stirred for $10 \mathrm{~min}$, and the solids were removed by filtration, which was additionally rinsed with DCM $(50 \mathrm{~mL})$. The combined filtrates were concentrated under reduced pressure and the residue was purified by Biotage Isolera LPLC to give the title compound $(R, R)-33 \mathbf{j}(2.36 \mathrm{~g}, 5.37 \mathrm{mmol}, 66 \%)$ as a white solid. ${ }^{1} \mathrm{H}$ NMR (400 MHz, DMSO- $\left.d_{6}\right) \delta 8.73-8.60(\mathrm{~m}, 2 \mathrm{H}), 8.08-7.97(\mathrm{~m}, 2 \mathrm{H}), 7.61(\mathrm{ddd}, J=7.4,4.7,1.5 \mathrm{~Hz}$, 1H), $6.83-6.68(\mathrm{~m}, 3 \mathrm{H}), 4.32-4.16(\mathrm{~m}, 4 \mathrm{H}), 4.09(\mathrm{~d}, J=12.2 \mathrm{~Hz}, 1 \mathrm{H}), 3.99-3.87$ (m, 2H), $2.01-1.86(\mathrm{~m}, 2 \mathrm{H}), 1.42(\mathrm{~s}, 9 \mathrm{H})$. Chiral HPLC (Chiralpak IE-H column, 4.6 $\mathrm{mm} \times 25 \mathrm{~cm}, 30 \% \mathrm{EtOH} /$ hexane, $1 \mathrm{~mL} / \mathrm{min}): \mathrm{R}_{\mathrm{t}}=28.43 \mathrm{~min},>99 \%$ ee.

\section{$N$-[(3R,5R)-5-(2,3-dihydro-1,4-benzodioxin-6-yl)-1-methylpiperidin-3-}

yllpyridine-2-carboxamide $((\boldsymbol{R}, \boldsymbol{R})-\mathbf{3 4 m})$. Step 1. To a stirred solution of $(R, R)-\mathbf{3 3} \mathbf{j}(2.3$ 
$\mathrm{g}, 5.23 \mathrm{mmol})$ in DCM was added trifluoroacetic acid $(4 \mathrm{~mL})$. The resulting mixture was stirred at ambient temperature for $4 \mathrm{~h}$. Then the solvent was removed under reduced pressure, and the crude product was redissolved in water $(50 \mathrm{~mL})$. The solution was basified to $\mathrm{pH} 10$ with $15 \%$ aq. $\mathrm{NaOH}$ and extracted with EtOAc $(80 \mathrm{~mL} \times 3)$. The combined organic layer was dried over anhydrous $\mathrm{Na}_{2} \mathrm{SO}_{4}$, filtered, and concentrated in vacuo to give $N$-[(3R,5R)-5-(2,3-dihydro-1,4-benzodioxin-6-yl)piperidin-3yl]pyridine-2-carboxamide (1.45 g, $4.27 \mathrm{mmol}, 82 \%)$ as a pale-yellow solid, which was used without further purification. ${ }^{1} \mathrm{H}$ NMR (400 MHz, DMSO- $\left.d_{6}\right) \delta 8.68-8.59(\mathrm{~m}$, $1 \mathrm{H}), 8.45(\mathrm{~d}, J=8.7 \mathrm{~Hz}, 1 \mathrm{H}), 8.08-7.92(\mathrm{~m}, 2 \mathrm{H}), 7.60(\mathrm{ddd}, J=7.4,4.8,1.5 \mathrm{~Hz}, 1 \mathrm{H})$, $6.76(\mathrm{~d}, J=8.1 \mathrm{~Hz}, 1 \mathrm{H}), 6.72-6.62(\mathrm{~m}, 2 \mathrm{H}), 4.31-4.10(\mathrm{~m}, 4 \mathrm{H}), 4.01-3.88(\mathrm{~m}, 1 \mathrm{H})$, $3.17(\mathrm{~d}, J=3.6 \mathrm{~Hz}, 1 \mathrm{H}), 3.07-2.95(\mathrm{~m}, 1 \mathrm{H}), 2.94-2.84(\mathrm{~m}, 1 \mathrm{H}), 2.69-2.58(\mathrm{~m}, 1 \mathrm{H})$, $2.48-2.38(\mathrm{~m}, 2 \mathrm{H}), 2.33(\mathrm{t}, J=11.7 \mathrm{~Hz}, 1 \mathrm{H}), 2.01-1.91(\mathrm{~m}, 1 \mathrm{H}), 1.77(\mathrm{q}, J=12.1$ $\mathrm{Hz}, 1 \mathrm{H})$.

Step 2. To a stirred solution of $N$-[(3R,5R)-5-(2,3-dihydro-1,4-benzodioxin-6yl)piperidin-3-yl]pyridine-2-carboxamide (1.45 g, $4.27 \mathrm{mmol})$ and glacial acetic acid $(0.1 \mathrm{~mL})$ in methanol $(50 \mathrm{~mL})$ was added $37 \% \mathrm{w} / \mathrm{v}$ formaldehyde $(0.42 \mathrm{~mL})$. Then sodium triacetoxyborohydride $(2.0 \mathrm{~g}, 9.44 \mathrm{mmol})$ was added portionwise $(0.5 \mathrm{~g}$ every $20 \mathrm{~min}$ ). 2 hours after the final addition, the solvent was removed in vacuo and the residue was partitioned between EtOAc and water. The biphasic solution was extracted twice with EtOAc. Then the combined organics were washed twice with brine, dried over $\mathrm{Na}_{2} \mathrm{SO}_{4}$, filtered, and concentrated. Purification of the residue by Biotage Isolera LPLC gave $(R, R)-34 \mathrm{~m}(1.1 \mathrm{~g}, 3.11 \mathrm{mmol}, 73 \%)$ as a white solid. ${ }^{1} \mathrm{H}$ NMR (400 MHz, 
DMSO- $\left.d_{6}\right) \delta 8.64(\mathrm{dt}, J=4.9,1.3 \mathrm{~Hz}, 1 \mathrm{H}), 8.53(\mathrm{~d}, J=8.7 \mathrm{~Hz}, 1 \mathrm{H}), 8.07-7.93(\mathrm{~m}$, 2H), $7.60(\mathrm{ddd}, J=7.6,4.7,1.5 \mathrm{~Hz}, 1 \mathrm{H}), 6.81-6.66(\mathrm{~m}, 3 \mathrm{H}), 4.28-4.17(\mathrm{~m}, 4 \mathrm{H}), 4.15$ $-4.02(\mathrm{~m}, 1 \mathrm{H}), 2.91(\mathrm{dd}, J=10.1,4.1 \mathrm{~Hz}, 1 \mathrm{H}), 2.83-2.72(\mathrm{~m}, 2 \mathrm{H}), 2.21(\mathrm{~s}, 3 \mathrm{H}), 2.01$ $-1.76(\mathrm{~m}, 3 \mathrm{H}), 1.67(\mathrm{q}, J=12.0 \mathrm{~Hz}, 1 \mathrm{H})$.

(3R,5R)-5-(2,3-dihydro-1,4-benzodioxin-6-yl)-1-methylpiperidin-3-amine $((\boldsymbol{R}, \boldsymbol{R})-35 \mathrm{~m})$. Compound $(R, R)-34 \mathrm{~m}(1.1 \mathrm{~g}, 3.11 \mathrm{mmol})$ was suspended in $i$-PrOH (40 $\mathrm{mL})$ in a $100 \mathrm{~mL}$ round-bottom flask. $\mathrm{NaOH}(1.24 \mathrm{~g}, 31.1 \mathrm{mmol})$ was added. The reaction mixture was stirred at $85{ }^{\circ} \mathrm{C}$ for $18 \mathrm{~h}$. Then the solvent was removed under reduced pressure and water $(50 \mathrm{~mL})$ was added. The solution was extracted with EtOAc $(50 \mathrm{~mL} \times 2)$, dried over $\mathrm{Na}_{2} \mathrm{SO}_{4}$, filtered, and removed the solvent to give the title compound (R,R)-35m (593 mg, $2.39 \mathrm{mmol}, 77 \%)$ as a pale-yellow solid without further purification. ${ }^{1} \mathrm{H}$ NMR $\left(400 \mathrm{MHz}, \mathrm{DMSO}-d_{6}\right) \delta 6.75(\mathrm{~d}, J=8.1 \mathrm{~Hz}, 1 \mathrm{H}), 6.71-6.60(\mathrm{~m}$, $2 \mathrm{H}), 4.28-4.13(\mathrm{~m}, 4 \mathrm{H}), 2.84-2.59(\mathrm{~m}, 4 \mathrm{H}), 2.15(\mathrm{~s}, 3 \mathrm{H}), 1.89-1.78(\mathrm{~m}, 1 \mathrm{H}), 1.67$ $(\mathrm{t}, J=10.7 \mathrm{~Hz}, 1 \mathrm{H}), 1.59-1.28(\mathrm{~m}, 3 \mathrm{H}), 1.04(\mathrm{q}, J=12.0 \mathrm{~Hz}, 1 \mathrm{H})$.

\section{3-methyl-2-\{[(3R,5R)-5-phenyl-1-(prop-2-en-1-yl)piperidin-3-yl]amino\}-}

3H,4H,5H-pyrrolo[3,2-d]pyrimidin-4-one $((\boldsymbol{R}, \boldsymbol{R})-36 \mathbf{a})$. Stepl. To a solution of $N$ [(3R,5R)-5-phenylpiperidin-3-yl]pyridine-2-carboxamide $(800 \mathrm{mg}, 2.84 \mathrm{mmol})$ and $\mathrm{Et}_{3} \mathrm{~N}$ (324 mg, $3.2 \mathrm{mmol}$ ) in MeCN was added 3-bromoprop-1-ene (387 mg, $3.2 \mathrm{mmol}$ ). The mixture was reacted at $70{ }^{\circ} \mathrm{C}$ for $8 \mathrm{~h}$. After cooling to ambient temperature, the mixture was concentrated and the residue was purified by LPLC to give $(R, R)-34 \mathbf{a}(690$ mg, $2.15 \mathrm{mmol}, 76 \%$ ) as a white solid. ${ }^{1} \mathrm{H}$ NMR (400 MHz, DMSO- $\left.d_{6}\right) \delta 8.67-8.61$ (m, 1H), $8.57(\mathrm{~d}, J=8.7 \mathrm{~Hz}, 1 \mathrm{H}), 8.08-7.95(\mathrm{~m}, 2 \mathrm{H}), 7.60$ (ddd, $J=7.3,4.7,1.5 \mathrm{~Hz}$, 
1H), $7.37-7.24(\mathrm{~m}, 4 \mathrm{H}), 7.24-7.16(\mathrm{~m}, 1 \mathrm{H}), 5.93-5.78(\mathrm{~m}, 1 \mathrm{H}), 5.22-5.08(\mathrm{~m}$, $2 \mathrm{H}), 4.17-4.06(\mathrm{~m}, 1 \mathrm{H}), 3.12-2.96(\mathrm{~m}, 3 \mathrm{H}), 2.96-2.83(\mathrm{~m}, 2 \mathrm{H}), 2.07-1.89(\mathrm{~m}$, $3 \mathrm{H}), 1.80(\mathrm{q}, J=12.0 \mathrm{~Hz}, 1 \mathrm{H})$.

Step 2. (3R,5R)-1-methyl-5-phenylpiperidin-3-amine $((R, R)-\mathbf{3 5 a})$ was prepared from $(R, R)$-34a using the procedure described for $(R, R)$-20a as colorless oil. The product was used immediately without further purification. LC-MS: $m / z$ 191.1 $(\mathrm{M}+\mathrm{H})^{+}$.

Step 3. The title compound $(R, R)-36$ a was prepared from 16 and $(R, R)$-35a using the procedure described for $(R, R)$-24a as a white solid. This product was further purified by reverse-phase HPLC. ${ }^{1} \mathrm{H}$ NMR (400 MHz, DMSO- $\left.d_{6}\right) \delta 11.44(\mathrm{~s}, 1 \mathrm{H}), 7.35-7.17$ $(\mathrm{m}, 6 \mathrm{H}), 6.18-5.97(\mathrm{~m}, 2 \mathrm{H}), 5.89-5.78(\mathrm{~m}, 1 \mathrm{H}), 5.28-5.04(\mathrm{~m}, 2 \mathrm{H}), 4.32-4.14(\mathrm{~m}$, 1H), $3.37(\mathrm{~s}, 3 \mathrm{H}), 3.18(\mathrm{dd}, J=10.5,4.3 \mathrm{~Hz}, 1 \mathrm{H}), 3.05-2.84(\mathrm{~m}, 4 \mathrm{H}), 2.11(\mathrm{dd}, J=$ 12.0, 4.1 Hz, 1H), $1.97-1.87(\mathrm{~m}, 2 \mathrm{H}), 1.68(\mathrm{q}, J=12.7 \mathrm{~Hz}, 1 \mathrm{H})$.

\section{2-\{[(3R,5R)-1-(2-hydroxyethyl)-5-phenylpiperidin-3-yl]amino\}-3-methyl-}

3H,4H,5H-pyrrolo[3,2-d]pyrimidin-4-one $((\boldsymbol{R}, \boldsymbol{R})-36 \mathrm{~b})$. The title compound $(R, R)$ 36b was prepared in the same manner as shown for $(R, R)$-36a except 2-bromoethan-1ol was used instead. ${ }^{1} \mathrm{H}$ NMR (400 MHz, DMSO- $\left.d_{6}\right) \delta 11.41(\mathrm{~s}, 1 \mathrm{H}), 7.35-7.19(\mathrm{~m}$, 5H), $7.16(\mathrm{t}, J=2.9 \mathrm{~Hz}, 1 \mathrm{H}), 6.06(\mathrm{t}, J=2.4 \mathrm{~Hz}, 1 \mathrm{H}), 6.00(\mathrm{~d}, J=7.8 \mathrm{~Hz}, 1 \mathrm{H}), 4.42(\mathrm{t}$, $J=5.3 \mathrm{~Hz}, 1 \mathrm{H}), 4.25-4.14(\mathrm{~m}, 1 \mathrm{H}), 3.57-3.48(\mathrm{~m}, 2 \mathrm{H}), 3.36(\mathrm{~s}, 3 \mathrm{H}), 3.18(\mathrm{dd}, J=$ 10.7, 4.1 Hz, 1H), $2.97(\mathrm{dd}, J=10.9,3.7 \mathrm{~Hz}, 1 \mathrm{H}), 2.94-2.83(\mathrm{~m}, 1 \mathrm{H}), 2.50-2.41(\mathrm{~m}$, $2 \mathrm{H}), 2.12-1.93(\mathrm{~m}, 3 \mathrm{H}), 1.65(\mathrm{q}, J=12.2 \mathrm{~Hz}, 1 \mathrm{H}) .{ }^{13} \mathrm{C}$ NMR $\left(101 \mathrm{MHz}, \mathrm{DMSO}-d_{6}\right) \delta$ $154.48,149.58,144.82,144.19,128.87,127.78,127.51,126.82,112.38,101.18,60.82$, 
60.61, 59.12, 58.96, 48.67, 41.74, 37.74, 27.70. HRMS $m / z 368.2083\left(\mathrm{M}+\mathrm{H}^{+}\right.$, $\mathrm{C}_{20} \mathrm{H}_{25} \mathrm{~N}_{5} \mathrm{O}_{2}$, requires 367.2008).

\section{3-methyl-2-\{[(3R,5R)-5-phenyl-1-(2-phenylethyl)piperidin-3-yl]amino\}-}

3H,4H,5H-pyrrolo[3,2-d]pyrimidin-4-one $((\boldsymbol{R}, \boldsymbol{R})-36 \mathrm{c})$. The title compound $(R, R)$ -

36b was prepared in the same manner as shown for $(R, R)$-36a except (2bromoethyl)benzene was used instead. ${ }^{1} \mathrm{H}$ NMR (400 MHz, DMSO- $\left.d_{6}\right) \delta 11.43(\mathrm{~s}, 1 \mathrm{H})$, $7.36-7.14(\mathrm{~m}, 11 \mathrm{H}), 6.07(\mathrm{t}, J=2.4 \mathrm{~Hz}, 1 \mathrm{H}), 6.03(\mathrm{~d}, J=7.7 \mathrm{~Hz}, 1 \mathrm{H}), 4.30-4.12(\mathrm{~m}$, 1H), $3.37(\mathrm{~s}, 3 \mathrm{H}), 3.32-3.26(\mathrm{~m}, 1 \mathrm{H}), 3.01(\mathrm{dd}, J=10.8,3.6 \mathrm{~Hz}, 1 \mathrm{H}), 2.91(\mathrm{td}, J=$ 12.1, 11.5, 3.7 Hz, 1H), $2.82-2.69(\mathrm{~m}, 2 \mathrm{H}), 2.62(\mathrm{t}, J=7.8 \mathrm{~Hz}, 2 \mathrm{H}), 2.22-1.88(\mathrm{~m}$, 3H), 1.69 (q, $J=12.1 \mathrm{~Hz}, 1 \mathrm{H}) .{ }^{13} \mathrm{C}$ NMR (101 MHz, DMSO-d $) \delta 154.49,149.59$, $144.85,144.15,140.91,129.20,128.87,128.66,127.81,127.54,126.83,126.25$, $112.40,101.20,60.42,60.11,58.11,48.75,41.73,37.73,33.10,27.70$. HRMS $m / z$ 428.2452 (M+ $\mathrm{H}^{+}, \mathrm{C}_{26} \mathrm{H}_{29} \mathrm{~N}_{5} \mathrm{O}$, requires 427.2372).

\section{2-\{[(3R,5R)-5-(3-bromophenyl)-1-methylpiperidin-3-yl]amino\}-3-methyl-}

3H,4H,5H-pyrrolo[3,2-d]pyrimidin-4-one $((\boldsymbol{R}, \boldsymbol{R})-36 \mathrm{~d})$. The title compound $(R, R)$ 36d was prepared in the same manner as shown for $(R, R)-\mathbf{2 4 a}$ except 1-bromo-3iodobenzene was used instead. ${ }^{1} \mathrm{H}$ NMR $\left(400 \mathrm{MHz}, \mathrm{DMSO}-d_{6}\right) \delta 11.43(\mathrm{~s}, 1 \mathrm{H}), 7.47$ (t, $J=1.4 \mathrm{~Hz}, 1 \mathrm{H}), 7.45-7.40(\mathrm{~m}, 1 \mathrm{H}), 7.32-7.26(\mathrm{~m}, 2 \mathrm{H}), 7.16(\mathrm{t}, J=2.9 \mathrm{~Hz}, 1 \mathrm{H}), 6.05$ (t, $J=2.4 \mathrm{~Hz}, 1 \mathrm{H}), 5.99(\mathrm{~d}, J=7.7 \mathrm{~Hz}, 1 \mathrm{H}), 4.25-4.12(\mathrm{~m}, 1 \mathrm{H}), 3.36(\mathrm{~s}, 3 \mathrm{H}), 3.10(\mathrm{dd}$, $J=10.5,4.2 \mathrm{~Hz}, 1 \mathrm{H}), 3.01-2.83(\mathrm{~m}, 2 \mathrm{H}), 2.23(\mathrm{~s}, 3 \mathrm{H}), 2.13-2.03(\mathrm{~m}, 1 \mathrm{H}), 1.91-$ $1.76(\mathrm{~m}, 2 \mathrm{H}), 1.61(\mathrm{q}, J=12.2 \mathrm{~Hz}, 1 \mathrm{H}) .{ }^{13} \mathrm{C}$ NMR (101 MHz, DMSO- $\left.d_{6}\right) \delta 154.46$, $149.53,146.90,144.79,131.07,130.28,129.75,127.78,126.72,122.22,112.41$, 
101.18, 62.22, 60.35, 48.51, 46.15, 41.22, 36.85, 27.69. HRMS $m / z 416.1082\left(\mathrm{M}+\mathrm{H}^{+}\right.$, $\mathrm{C}_{19} \mathrm{H}_{22} \mathrm{BrN}_{5} \mathrm{O}$, requires 415.1008).

\section{2-\{[(3R,5R)-5-(4-methoxyphenyl)-1-methylpiperidin-3-yl]amino\}-3-methyl-}

3H,4H,5H-pyrrolo[3,2-d]pyrimidin-4-one $((\boldsymbol{R}, \boldsymbol{R})-36 \mathrm{e})$. The title compound $(R, R)$ 36e was prepared in the same manner as shown for $(R, R)$-24a except 1-iodo-4methoxybenzene was used instead. ${ }^{1} \mathrm{H}$ NMR (400 MHz, DMSO- $\left.d_{6}\right) \delta 11.43(\mathrm{~s}, 1 \mathrm{H})$, $7.23-7.12(\mathrm{~m}, 3 \mathrm{H}), 6.92-6.83(\mathrm{~m}, 2 \mathrm{H}), 6.06(\mathrm{t}, J=2.4 \mathrm{~Hz}, 1 \mathrm{H}), 6.00(\mathrm{~d}, J=7.7 \mathrm{~Hz}$, 1H), $4.26-4.12(\mathrm{~m}, 1 \mathrm{H}), 3.73(\mathrm{~s}, 3 \mathrm{H}), 3.10(\mathrm{dd}, J=10.5,4.1 \mathrm{~Hz}, 1 \mathrm{H}), 2.89-2.77(\mathrm{~m}$, 2H), $2.23(\mathrm{~s}, 3 \mathrm{H}), 2.05(\mathrm{~d}, J=11.9 \mathrm{~Hz}, 1 \mathrm{H}), 1.82(\mathrm{dt}, J=12.6,10.6 \mathrm{~Hz}, 2 \mathrm{H}), 1.58(\mathrm{q}, J$ $=12.2 \mathrm{~Hz}, 1 \mathrm{H}) .{ }^{13} \mathrm{C}$ NMR $\left(101 \mathrm{MHz}, \mathrm{DMSO}-d_{6}\right) \delta 158.23,154.47,149.58,144.81$, $136.02,128.36,127.78,114.25,112.40,101.18,62.93,60.42,55.46,48.69,46.20$, 40.81, 37.35, 27.71. HRMS $m / z$ 368.2089 ( $\mathrm{M}+\mathrm{H}^{+}, \mathrm{C}_{20} \mathrm{H}_{25} \mathrm{~N}_{5} \mathrm{O}_{2}$, requires 367.2008).

\section{2-\{[(3R,5R)-5-(4-butylphenyl)-1-methylpiperidin-3-yl]amino\}-3-methyl-}

3H,4H,5H-pyrrolo[3,2-d]pyrimidin-4-one ((R, $\boldsymbol{R})-36 \mathbf{f})$. The title compound $(R, R)-\mathbf{3 6 f}$ was prepared in the same manner as shown for $(R, R)$-24a except 1-butyl-4-iodobenzene was used instead. ${ }^{1} \mathrm{H}$ NMR (400 MHz, DMSO- $\left.d_{6}\right) \delta 11.44(\mathrm{~s}, 1 \mathrm{H}), 7.28-7.05(\mathrm{~m}, 5 \mathrm{H})$, $6.07(\mathrm{t}, \mathrm{J}=2.5 \mathrm{~Hz}, 1 \mathrm{H}), 6.00(\mathrm{~d}, J=7.8 \mathrm{~Hz}, 1 \mathrm{H}), 4.29-4.11(\mathrm{~m}, 1 \mathrm{H}), 3.37(\mathrm{~s}, 3 \mathrm{H}), 3.11$ (dd, $J=10.5,4.2 \mathrm{~Hz}, 1 \mathrm{H}), 2.93-2.77(\mathrm{~m}, 2 \mathrm{H}), 2.57-2.50(\mathrm{~m}, 2 \mathrm{H}), 2.23(\mathrm{~s}, 3 \mathrm{H}), 2.07$ $(\mathrm{d}, J=12.1 \mathrm{~Hz}, 1 \mathrm{H}), 1.91-1.75(\mathrm{~m}, 2 \mathrm{H}), 1.67-1.48(\mathrm{~m}, 3 \mathrm{H}), 1.38-1.20(\mathrm{~m}, 2 \mathrm{H})$, $0.88(\mathrm{t}, J=7.3 \mathrm{~Hz}, 3 \mathrm{H}) .{ }^{13} \mathrm{C}$ NMR $\left(101 \mathrm{MHz}, \mathrm{DMSO}-d_{6}\right) \delta 154.49,149.57,144.83$, $141.23,140.71,128.72,127.76,127.28,112.42,101.18,62.77,60.47,48.70,46.22$, 
$41.30,37.19,34.88,33.63,27.70,22.22,14.23$. HRMS $m / z 394.2610\left(\mathrm{M}+\mathrm{H}^{+}\right.$, $\mathrm{C}_{23} \mathrm{H}_{31} \mathrm{~N}_{5} \mathrm{O}$, requires 393.2529).

\section{3-methyl-2-\{[(3R,5R)-1-methyl-5-[4-(trifluoromethoxy)phenyl]piperidin-3-}

yl]amino\}-3H,4H,5H-pyrrolo[3,2-d]pyrimidin-4-one $\quad((\boldsymbol{R}, \boldsymbol{R})-36 g) . \quad$ The title compound $(R, R)$-36g was prepared in the same manner as shown for $(R, R)$-24a except 1-iodo-4-(trifluoromethoxy)benzene was used instead. ${ }^{1} \mathrm{H}$ NMR (400 MHz, DMSO- $\left.d_{6}\right)$ $\delta 11.44(\mathrm{~s}, 1 \mathrm{H}), 7.46-7.37(\mathrm{~m}, 2 \mathrm{H}), 7.31(\mathrm{~d}, J=8.2 \mathrm{~Hz}, 2 \mathrm{H}), 7.16(\mathrm{t}, J=2.9 \mathrm{~Hz}, 1 \mathrm{H})$, $6.06(\mathrm{t}, J=2.4 \mathrm{~Hz}, 1 \mathrm{H}), 6.01(\mathrm{~d}, J=7.7 \mathrm{~Hz}, 1 \mathrm{H}), 4.29-4.13(\mathrm{~m}, 1 \mathrm{H}), 3.36(\mathrm{~s}, 3 \mathrm{H})$, $3.11(\mathrm{dd}, J=10.5,4.1 \mathrm{~Hz}, 1 \mathrm{H}), 3.04-2.94(\mathrm{~m}, 1 \mathrm{H}), 2.87(\mathrm{dd}, J=11.0,3.6 \mathrm{~Hz}, 1 \mathrm{H})$, $2.24(\mathrm{~s}, 3 \mathrm{H}), 2.10(\mathrm{dt}, J=12.9,3.8 \mathrm{~Hz}, 1 \mathrm{H}), 1.92-1.77(\mathrm{~m}, 2 \mathrm{H}), 1.60(\mathrm{q}, J=12.2 \mathrm{~Hz}$ 1H). ${ }^{13} \mathrm{C}$ NMR (101 MHz, DMSO- $\left.d_{6}\right) \delta 154.46,149.55,147.28,144.79,143.50,129.28$, $127.77,121.85,121.44,119.30,112.42,101.18,62.32,60.36,48.58,46.17,40.99$, 37.10, 27.70. HRMS $m / z$ 422.1832 ( $\mathrm{M}+\mathrm{H}^{+}, \mathrm{C}_{20} \mathrm{H}_{22} \mathrm{~F}_{3} \mathrm{~N}_{5} \mathrm{O}_{2}$, requires 421.1726).

\section{2-\{[(3R,5R)-5-[4-chloro-3-(trifluoromethyl)phenyl]-1-methylpiperidin-3-}

yl]amino\}-3-methyl-3H,4H,5H-pyrrolo[3,2-d]pyrimidin-4-one $\quad((\boldsymbol{R}, \boldsymbol{R})-36 \mathrm{~h}) . \quad$ The title compound $(R, R)$-36h was prepared in the same manner as shown for $(R, R)$-24a except 1-chloro-4-iodo-2-(trifluoromethyl)benzene was used instead. ${ }^{1} \mathrm{H}$ NMR (400 MHz, DMSO- $\left.d_{6}\right) \delta 11.45(\mathrm{~s}, 1 \mathrm{H}), 7.76-7.60(\mathrm{~m}, 3 \mathrm{H}), 7.17(\mathrm{t}, J=2.9 \mathrm{~Hz}, 1 \mathrm{H}), 6.06(\mathrm{t}$, $J=2.4 \mathrm{~Hz}, 1 \mathrm{H}), 6.02(\mathrm{~d}, J=7.7 \mathrm{~Hz}, 1 \mathrm{H}), 4.29-4.17(\mathrm{~m}, 1 \mathrm{H}), 3.38(\mathrm{~s}, 3 \mathrm{H}), 3.16-3.04$ (m, 2H), $2.90(\mathrm{dd}, J=10.9,3.9 \mathrm{~Hz}, 1 \mathrm{H}), 2.25(\mathrm{~s}, 3 \mathrm{H}), 2.12(\mathrm{dt}, J=12.4,4.0 \mathrm{~Hz}, 1 \mathrm{H})$, $1.93-1.82(\mathrm{~m}, 2 \mathrm{H}), 1.63(\mathrm{q}, J=12.2 \mathrm{~Hz}, 1 \mathrm{H}) .{ }^{13} \mathrm{C}$ NMR $\left(101 \mathrm{MHz}, \mathrm{DMSO}-d_{6}\right) \delta$ $154.46,149.52,144.77,144.08,133.38,132.14,129.01,127.78,126.87,126.76$ 
$126.71,112.43,101.18,61.88,60.24,48.42,46.08,40.74,36.66,27.69$. HRMS $m / z$ 440.1476 $\left(\mathrm{M}+\mathrm{H}^{+}, \mathrm{C}_{20} \mathrm{H}_{21} \mathrm{ClF}_{3} \mathrm{~N}_{5} \mathrm{O}\right.$, requires 439.1387).

\section{2-\{[(3R,5R)-5-[4-(benzyloxy)phenyl]-1-methylpiperidin-3-yl]amino\}-3-}

methyl-3H,4H,5H-pyrrolo[3,2-d]pyrimidin-4-one $((\boldsymbol{R}, \boldsymbol{R})-36 \mathbf{i})$. The title compound $(R, R)$-36i was prepared in the same manner as shown for $(R, R)-24 a$ except 1(benzyloxy)-4-iodobenzene was used instead. ${ }^{1} \mathrm{H}$ NMR (400 MHz, DMSO- $\left.d_{6}\right) \delta 11.43$ (s, 1H), $7.45-7.37(\mathrm{~m}, 4 \mathrm{H}), 7.35-7.30(\mathrm{~m}, 1 \mathrm{H}), 7.21-7.14(\mathrm{~m}, 3 \mathrm{H}), 7.00-6.94(\mathrm{~m}$, 2H), $6.06(\mathrm{t}, J=2.4 \mathrm{~Hz}, 1 \mathrm{H}), 5.98(\mathrm{~d}, J=7.7 \mathrm{~Hz}, 1 \mathrm{H}), 5.07(\mathrm{~s}, 2 \mathrm{H}), 4.25-4.12(\mathrm{~m}$, 1H), $3.36(\mathrm{~s}, 3 \mathrm{H}), 3.13-3.05(\mathrm{~m}, 1 \mathrm{H}), 2.87-2.76(\mathrm{~m}, 2 \mathrm{H}), 2.22(\mathrm{~s}, 3 \mathrm{H}), 2.09-2.01$ $(\mathrm{m}, 1 \mathrm{H}), 1.86-1.74(\mathrm{~m}, 2 \mathrm{H}), 1.57(\mathrm{q}, J=12.3 \mathrm{~Hz}, 1 \mathrm{H}) .{ }^{13} \mathrm{C}$ NMR $(101 \mathrm{MHz}$, DMSO$\left.d_{6}\right) \delta 157.33,154.48,149.58,144.82,137.70,136.32,128.86,128.39,128.20,128.05$, 127.76, 115.17, 112.41, 101.19, 69.62, 62.92, 60.46, 48.71, 46.22, 40.84, 37.37, 27.71. HRMS $m / z 444.2394\left(\mathrm{M}+\mathrm{H}^{+}, \mathrm{C}_{26} \mathrm{H}_{29} \mathrm{~N}_{5} \mathrm{O}_{2}\right.$, requires 443.2321).

\section{2-\{[(3R,5R)-5-(4-hydroxyphenyl)-1-methylpiperidin-3-yl]amino\}-3-methyl-}

3H,4H,5H-pyrrolo[3,2-d]pyrimidin-4-one $((\boldsymbol{R}, \boldsymbol{R})-36 \mathbf{j})$. A stirred solution of $(R, R)$ 36i (660 mg, $1.49 \mathrm{mmol}$ ) and $10 \% \mathrm{Pd} / \mathrm{C}$ in $\mathrm{MeOH}$ was carefully evacuated and backfilled with $\mathrm{H}_{2}$ atmosphere and finally allowed to stir at ambient temperature overnight with a $\mathrm{H}_{2}$ balloon attached. Upon reaction completion the suspension was filtered through celite with $\mathrm{MeOH}$ washings. The filtrate was then concentrated and the residue was purified by Biotage Isolera LPLC (DCM/MeOH/Et ${ }_{3} \mathrm{~N}$ 60:1:0.2- 15:1:0.05) to give $(R, R)-36 \mathbf{j}(340 \mathrm{mg}, 65 \%)$ as a white solid. ${ }^{1} \mathrm{H}$ NMR (400 MHz, DMSO- $\left.d_{6}\right) \delta$ $11.42(\mathrm{~s}, 1 \mathrm{H}), 9.21(\mathrm{~s}, 1 \mathrm{H}), 7.15(\mathrm{t}, J=2.9 \mathrm{~Hz}, 1 \mathrm{H}), 7.10-7.03(\mathrm{~m}, 2 \mathrm{H}), 6.74-6.69$ 
$(\mathrm{m}, 2 \mathrm{H}), 6.05(\mathrm{t}, J=2.4 \mathrm{~Hz}, 1 \mathrm{H}), 5.99(\mathrm{~d}, J=7.7 \mathrm{~Hz}, 1 \mathrm{H}), 4.24-4.11(\mathrm{~m}, 1 \mathrm{H}), 3.36(\mathrm{~s}$, $3 \mathrm{H}), 3.14-3.06(\mathrm{~m}, 1 \mathrm{H}), 2.85-2.77(\mathrm{~m}, 2 \mathrm{H}), 2.23(\mathrm{~s}, 3 \mathrm{H}), 2.03(\mathrm{~d}, J=12.4 \mathrm{~Hz}, 1 \mathrm{H})$, $1.87-1.77(\mathrm{~m}, 2 \mathrm{H}), 1.55(\mathrm{q}, J=12.3 \mathrm{~Hz}, 1 \mathrm{H}) .{ }^{13} \mathrm{C}$ NMR $\left(101 \mathrm{MHz}, \mathrm{DMSO}-d_{6}\right) \delta$ $156.24,154.48,149.58,144.81,134.13,128.25,127.78,115.60,112.41,101.18,62.87$, 60.25, 48.64, 46.09, 40.72, 37.38, 27.73. HRMS $m / z 354.1927\left(\mathrm{M}+\mathrm{H}^{+}, \mathrm{C}_{19} \mathrm{H}_{23} \mathrm{~N}_{5} \mathrm{O}_{2}\right.$, requires 353.1852$)$.

\section{3-methyl-2-\{[(3R,5R)-1-methyl-5-(3-phenylphenyl)piperidin-3-yl]amino\}-}

3H,4H,5H-pyrrolo[3,2-d]pyrimidin-4-one $((\boldsymbol{R}, \boldsymbol{R})-36 \mathrm{k})$. The title compound $(R, R)$ 36k was prepared in the same manner as shown for $(R, R)$-24a except 1-iodo-3phenylbenzene was used instead. ${ }^{1} \mathrm{H}$ NMR (400 MHz, DMSO- $\left.d_{6}\right) \delta 11.45(\mathrm{~s}, 1 \mathrm{H}), 7.70$ $-7.62(\mathrm{~m}, 2 \mathrm{H}), 7.57-7.34(\mathrm{~m}, 6 \mathrm{H}), 7.31-7.25(\mathrm{~m}, 1 \mathrm{H}), 7.17(\mathrm{t}, J=2.9 \mathrm{~Hz}, 1 \mathrm{H}), 6.08$ (t, $J=2.4 \mathrm{~Hz}, 1 \mathrm{H}), 6.01(\mathrm{~d}, J=7.8 \mathrm{~Hz}, 1 \mathrm{H}), 4.33-4.18(\mathrm{~m}, 1 \mathrm{H}), 3.38(\mathrm{~s}, 3 \mathrm{H}), 3.14(\mathrm{dd}$, $J=10.4,4.1 \mathrm{~Hz}, 1 \mathrm{H}), 3.07-2.87(\mathrm{~m}, 2 \mathrm{H}), 2.25(\mathrm{~s}, 3 \mathrm{H}), 2.18-2.11(\mathrm{~m}, 1 \mathrm{H}), 1.96(\mathrm{t}, J$ $=10.5 \mathrm{~Hz}, 1 \mathrm{H}), 1.85(\mathrm{t}, J=10.5 \mathrm{~Hz}, 1 \mathrm{H}), 1.71(\mathrm{q}, J=12.1 \mathrm{~Hz}, 1 \mathrm{H}) .{ }^{13} \mathrm{C}$ NMR $(101$ MHz, DMSO- $\left.d_{6}\right) \delta 154.50,149.59,144.85,144.73,140.82,140.80,129.48,129.34$, $127.85,127.80,127.20,126.62,126.03,125.29,112.43,101.21,62.66,60.47,48.68$, 46.20, 41.72, 37.02, 27.71. HRMS $m / z 414.2290\left(\mathrm{M}+\mathrm{H}^{+}, \mathrm{C}_{25} \mathrm{H}_{27} \mathrm{~N}_{5} \mathrm{O}\right.$, requires 413.2216).

\section{3-methyl-2-\{[(3R,5R)-1-methyl-5-(4-phenoxyphenyl)piperidin-3-yl]amino\}-}

3H,4H,5H-pyrrolo[3,2-d]pyrimidin-4-one $((\boldsymbol{R}, \boldsymbol{R})-36 \mathrm{l})$. The title compound $(R, R)-36 \mathbf{I}$ was prepared in the same manner as shown for $(R, R)$-24a except 1-iodo-4phenoxybenzene was used instead. ${ }^{1} \mathrm{H}$ NMR (400 MHz, DMSO-d $) \delta 11.44(\mathrm{~s}, 1 \mathrm{H})$, 
$7.45-7.32(\mathrm{~m}, 2 \mathrm{H}), 7.34-7.24(\mathrm{~m}, 2 \mathrm{H}), 7.20-7.08(\mathrm{~m}, 2 \mathrm{H}), 7.03-6.89(\mathrm{~m}, 4 \mathrm{H})$, $6.06(\mathrm{t}, J=2.4 \mathrm{~Hz}, 1 \mathrm{H}), 6.00(\mathrm{~d}, J=8.5 \mathrm{~Hz}, 1 \mathrm{H}), 4.28-4.13(\mathrm{~m}, 1 \mathrm{H}), 3.15-3.07(\mathrm{~m}$, 1H), $2.98-2.81(\mathrm{~m}, 2 \mathrm{H}), 2.24(\mathrm{~s}, 3 \mathrm{H}), 2.14-2.05(\mathrm{~m}, 1 \mathrm{H}), 1.93-1.72(\mathrm{~m}, 3 \mathrm{H}), 1.60$ $(\mathrm{q}, J=12.1 \mathrm{~Hz}, 1 \mathrm{H}) .{ }^{13} \mathrm{C}$ NMR $\left(101 \mathrm{MHz}, \mathrm{DMSO}-d_{6}\right) \delta 157.35,155.48,154.48,149.57$, $144.81,139.19,130.46,128.96,127.77,123.72,119.15,118.89,112.42,101.19,62.68$ 60.38, 48.66, 46.19, 40.94, 37.27, 27.71. HRMS $m / z$ 430.2237 ( $\mathrm{M}+\mathrm{H}^{+}, \mathrm{C}_{25} \mathrm{H}_{27} \mathrm{~N}_{5} \mathrm{O}_{2}$, requires 429.2165$)$.

\section{3-methyl-2-\{[(3R,5R)-1-methyl-5-(naphthalen-2-yl)piperidin-3-yl]amino\}-}

3H,4H,5H-pyrrolo[3,2-d]pyrimidin-4-one $((\boldsymbol{R}, \boldsymbol{R})-36 \mathrm{~m})$. The title compound $(R, R)$ 36m was prepared in the same manner as shown for $(R, R)-\mathbf{2 4 a}$ except 2iodonaphthalene was used instead. ${ }^{1} \mathrm{H}$ NMR (400 MHz, DMSO-d6) $\delta 11.41(\mathrm{~s}, 1 \mathrm{H})$, $7.87(\mathrm{~d}, J=7.8 \mathrm{~Hz}, 3 \mathrm{H}), 7.77(\mathrm{~s}, 1 \mathrm{H}), 7.57-7.40(\mathrm{~m}, 3 \mathrm{H}), 7.17(\mathrm{t}, J=2.9 \mathrm{~Hz}, 1 \mathrm{H})$, $6.12-6.00(\mathrm{~m}, 2 \mathrm{H}), 4.31-4.19(\mathrm{~m}, 1 \mathrm{H}), 3.37(\mathrm{~s}, 3 \mathrm{H}), 3.19-3.03(\mathrm{~m}, 2 \mathrm{H}), 3.00-2.92$ $(\mathrm{m}, 1 \mathrm{H}), 2.27(\mathrm{~s}, 3 \mathrm{H}), 2.22-2.12(\mathrm{~m}, 1 \mathrm{H}), 2.00(\mathrm{t}, J=11.1 \mathrm{~Hz}, 1 \mathrm{H}), 1.88(\mathrm{t}, J=10.5$ $\mathrm{Hz}, 1 \mathrm{H}), 1.73$ (q, $J=12.1 \mathrm{~Hz}, 1 \mathrm{H}) .{ }^{13} \mathrm{C} \mathrm{NMR}\left(101 \mathrm{MHz}, \mathrm{DMSO}-d_{6}\right) \delta 154.50,149.61$, $144.83,141.63,133.61,132.36,128.27,127.98,127.88,126.61,126.51,125.92$, 125.30, 112.38, 101.20, 62.44, 60.43, 48.72, 46.23, 41.66, 37.07, 27.73. HRMS $m / z$ 388.2136 $\left(\mathrm{M}+\mathrm{H}^{+}, \mathrm{C}_{23} \mathrm{H}_{25} \mathrm{~N}_{5} \mathrm{O}\right.$, requires 387.2059).

\section{2-\{[(3R,5R)-5-(2,3-dihydro-1,4-benzodioxin-6-yl)-1-methylpiperidin-3-}

yl]amino\}-3-methyl-3H,4H,5H-pyrrolo[3,2-d]pyrimidin-4-one $\quad((R, R)-36 n) . \quad$ A solution of DIPEA (183 mg, $1.42 \mathrm{mmol})$ in NMP (5 mL) was treated with 16 (200 mg, $1.09 \mathrm{mmol})$ and $(R, R)-\mathbf{3 5 m}(325 \mathrm{mg}, 1.31 \mathrm{mmol})$. The resulting mixture was heated to 
$150{ }^{\circ} \mathrm{C}$ and stirred at this temperature for $2 \mathrm{~h}$. After cooling to ambient temperature, the mixture was diluted with water and extracted with EtOAc. The combined organic phase was washed with brine, dried over $\mathrm{Na}_{2} \mathrm{SO}_{4}$, and concentrated in vacuo. Purification of the residue by Biotage Isolera LPLC gave the title compound $(R, R)-36 n(53 \mathrm{mg}, 134$ mmol, $12 \%$ ) as a white solid. ${ }^{1} \mathrm{H}$ NMR (400 MHz, DMSO- $\left.d_{6}\right) \delta 11.42(\mathrm{~s}, 1 \mathrm{H}), 7.15(\mathrm{t}$, $J=2.9 \mathrm{~Hz}, 1 \mathrm{H}), 6.82-6.69(\mathrm{~m}, 3 \mathrm{H}), 6.05(\mathrm{t}, J=2.4 \mathrm{~Hz}, 1 \mathrm{H}), 5.98(\mathrm{~d}, J=7.8 \mathrm{~Hz}, 1 \mathrm{H})$, $4.27-4.13(\mathrm{~m}, 5 \mathrm{H}), 3.35$ (s, 3H), 3.09 (dd, $J=10.7,4.3 \mathrm{~Hz}, 1 \mathrm{H}), 2.90-2.76(\mathrm{~m}, 2 \mathrm{H})$, $2.21(\mathrm{~s}, 3 \mathrm{H}), 2.02(\mathrm{~d}, J=10.2,6.4 \mathrm{~Hz}, 1 \mathrm{H}), 1.89-1.77(\mathrm{~m}, 2 \mathrm{H}), 1.55(\mathrm{q}, J=12.2 \mathrm{~Hz}$, 1H). ${ }^{13} \mathrm{C}$ NMR (101 MHz, DMSO- $\left.d_{6}\right) \delta 154.46,149.55,144.79,143.63,142.31,137.10$, $127.77,120.08,117.31,115.95,112.40,101.17,64.54,64.44,62.73,60.33,48.55$, 46.12, 40.82, 37.17, 27.70. HRMS $m / z 396.2035\left(\mathrm{M}+\mathrm{H}^{+}, \mathrm{C}_{21} \mathrm{H}_{25} \mathrm{~N}_{5} \mathrm{O}_{3}\right.$, requires 395.1957). Chiral HPLC (Chiralpak IE-H column, $4.6 \mathrm{~mm} \times 25 \mathrm{~cm}, i$ PrOH/Hexane $\left./ \mathrm{EtN}_{3}=30: 70: 0.14,1 \mathrm{~mL} / \mathrm{min}\right): \mathrm{R}_{\mathrm{t}}=31.54 \mathrm{~min},>99 \%$ ee.

\section{3-methyl-2-\{[(3S,5S)-1-methyl-5-phenylpiperidin-3-yl]amino\}-3H,4H,5H-}

pyrrolo[3,2-d]pyrimidin-4-one $((S, S)-36 n)$. The title compound $(S, S)-36 n$ was prepared as a white solid by the same procedures as $(R, R)-\mathbf{3 6 n}$ except the starting material tert-butyl (3S)-3-(pyridine-2-amido)piperidine-1-carboxylate $(S)$-18a was used instead. ${ }^{1} \mathrm{H}$ NMR (400 MHz, DMSO- $\left.d_{6}\right) \delta 7.43(\mathrm{~d}, J=3.0 \mathrm{~Hz}, 1 \mathrm{H}), 6.84-6.66$ (m, 3H), $6.41(\mathrm{~d}, J=8.1 \mathrm{~Hz}, 1 \mathrm{H}), 6.26(\mathrm{~d}, J=3.0 \mathrm{~Hz}, 1 \mathrm{H}), 4.46-4.30(\mathrm{~m}, 1 \mathrm{H}), 4.21$ (s, 4H), $4.01(\mathrm{~s}, 3 \mathrm{H}), 3.31(\mathrm{~s}, 3 \mathrm{H}), 3.11-2.96(\mathrm{~m}, 1 \mathrm{H}), 2.91-2.74(\mathrm{~m}, 2 \mathrm{H}), 2.24(\mathrm{~s}$, $3 \mathrm{H}), 2.04-1.79(\mathrm{~m}, 3 \mathrm{H}), 1.69(\mathrm{q}, J=12.0 \mathrm{~Hz}, 1 \mathrm{H}) .{ }^{13} \mathrm{C}$ NMR (101 MHz, DMSO-d6) $\delta 151.12,150.92,150.33,143.64,142.34,137.01,135.21,120.12,117.30,115.98$, 
$113.83,100.49,64.55,64.45,62.48,59.70,47.58,46.14,40.69,36.85,36.73$. HRMS $m / z 396.2040\left(\mathrm{M}+\mathrm{H}^{+}, \mathrm{C}_{21} \mathrm{H}_{25} \mathrm{~N}_{5} \mathrm{O}_{3}\right.$, requires 395.1957). Chiral HPLC (Chiralpak IE$\mathrm{H}$ column, $\left.4.6 \mathrm{~mm} \times 25 \mathrm{~cm}, i-\mathrm{PrOH} / \mathrm{Hexane} / \mathrm{EtN}_{3}=30: 70: 0.14,1 \mathrm{~mL} / \mathrm{min}\right): \mathrm{R}_{\mathrm{t}}=21.65$ $\min ,>99 \%$ ee.

4.2. Protein Expression and Purification. For the isothermal-titration calorimetry (ITC), thermal-shift assay (TSA), and crystallogenesis, human PCAF, GCN5, BRD4(1), ATAD2, BAZ2B, BRD9, BRPF1, BRPF3, EP300, FALZ, TAF1(1), and TRIM24 bromodomains were expressed and purified according to the protocols previously described. ${ }^{1}$ All proteins were expressed as $N$-terminal His-tagged fusions and purified using Ni-chelating affinity chromatography. Then these proteins were purified by gel filtration using Superdex200 column, eluted with buffer containing $10 \mathrm{mM}$ HEPES pH 7.5 and $500 \mathrm{mM} \mathrm{NaCl}$, concentrated to $3 \mathrm{mg} / \mathrm{mL}$, and frozen at $-80{ }^{\circ} \mathrm{C}$ for thermal shift assays. PCAF and GCN5 BRDs were further treated with TEV protease at $4{ }^{\circ} \mathrm{C}$ overnight to cleave $\mathrm{N}$-terminal His-tag. The two proteins were then purified by gel filtration chromatography (Superdex 200; GE-Healthcare), concentrated to $12 \mathrm{mg} / \mathrm{mL}$, flash-frozen in liquid nitrogen, and stored at $-80^{\circ} \mathrm{C}$ for ITC assays and crystallogenesis.

For the homogeneous time-resolved fluorescence (HTRF) experiments, GSTtagged PCAF was cloned into pET28a vector and overexpressed in Escherichia coli Rosetta (DE3). Purification was carried on GST-affinity resin (Thermo Scientific), and reduced glutathione was used for protein release. GST-PCAF was further purified by gel filtration chromatography on a Superdex 200 column (GE Healthcare) using a buffer of $25 \mathrm{mM}$ HEPES (pH 7.5) and $300 \mathrm{mM} \mathrm{NaCl}$. 
4.3. Thermal-Shift Assay (TSA). The TSA experiments were performed at least in duplicate. Proteins were prepared in $10 \mathrm{mM}$ HEPES pH 7.5, $500 \mathrm{mM} \mathrm{NaCl}$, and assayed in low-profile PCR tubes (Bio-Rad, TLS0851) at a final concentration of $2 \mu \mathrm{M}$ in $20-\mu \mathrm{L}$ volume. Compounds were added at a final concentration of $10 \mu \mathrm{M}$ (final concentration $0.1 \%$ DMSO). SYPRO Orange dye (Thermo Fisher Scientific) was added at a dilution of 1:1000. The thermal melting experiments were carried using a Bio-Rad CFX96 RT-PCR system. The tubes were first equilibrated at $25{ }^{\circ} \mathrm{C}$ for $3 \mathrm{~min}$, then the tubes were heated from 25 to $95{ }^{\circ} \mathrm{C}$ with a step of $1{ }^{\circ} \mathrm{C} / \mathrm{min}$. Raw fluorescence data were recorded using CFX Maestro, melting temperature shifts were calculated as previously described. ${ }^{34}$

4.4. Isothermal-Titration Calorimetry (ITC). ITC was used to evaluate the thermodynamics parameters of the binding between PCAF bromodomain and all the final compounds. Titrations were carried out on a MicroCal ITC200 microcalorimeter (Malvern Instruments). All experiments were carried out at $25{ }^{\circ} \mathrm{C}$ in $25 \mathrm{mM}$ HEPES (pH 7.5), $300 \mathrm{mM} \mathrm{NaCl}, 0.5 \mathrm{mM}$ TCEP. Compounds were diluted directly in the same batch buffer prior to experiments. Each experiment was designed as reverse titrations experiments (protein in the syringe and ligand in the cell) using an initial injection of $0.4 \mu \mathrm{L}$ followed by 19 injections of $2 \mu \mathrm{L}$. The first injection (generally $0.4 \mu \mathrm{L}$ ) was included in the titration protocol in order to remove air bubbles trapped in the syringe prior to the titration. Background dilution heat was subtracted from each experiment. Thermodynamic parameters were calculated using $\Delta \mathrm{G}=\Delta \mathrm{H}-\mathrm{T} \Delta \mathrm{S}=-\mathrm{RT} \ln \mathrm{K}_{\mathrm{A}}$, where $\mathrm{K}_{\mathrm{D}}=1 / \mathrm{K}_{\mathrm{A}} \cdot \Delta \mathrm{G}, \Delta \mathrm{H}$ and $\Delta \mathrm{S}$ are changes in free energy, enthalpy and entropy respectively. Independent single site binding models were employed in data analysis.

4.5. Homogeneous Time-Resolved Fluorescence (HTRF). HTRF assay was carried out using a Cisbio EPIgeneous Binding Domain Kit B (62BDBPEG) using the 
standard assay protocol with GST-PCAF BRD and biotinylated substrate 46 . The protein GST-PCAF BRD was produced and purified in house. The biotinylated substrate 46 was a kind gift from Prof. Dr. P. E. Brennan (Oxford University). The $\mathrm{IC}_{50}$ measurements were performed in duplicate. $4 \mathrm{uL}$ GST-PCAF BRD $(100 \mathrm{nM}), 2 \mathrm{uL}$ tested compounds, $4 \mathrm{uL}$ compound 46 (500 nM), $5 \mathrm{uL} \mathrm{SA-XL665} \mathrm{(250} \mathrm{nM),} \mathrm{and} 5 \mathrm{uL}$ $1 \times \mathrm{GST} \mathrm{Ab}-\mathrm{Eu}^{3+}$ were added into a 96-well low-volume plate (Cisbio 66PL96025), then the plate was sealed and incubated at room temperature for 15 hours. Readings were recorded using Cytation Hybrid Multi-Mode Reader with an excitation filter at $337 \mathrm{~nm}$ and fluorescence measurement at 620 and $665 \mathrm{~nm}(60 \mu$ s integration delay and $400 \mu \mathrm{s}$ integration time). The $\mathrm{IC}_{50}$ values were normalized and fitted with Prism 7.

4.6. BROMOscan. Bromodomain profiling was provided by DiscoveRx Corp. using their BROMOscan platform (http://www.discoverx.com/). ${ }^{35}(R, R)-36 \mathbf{n}$ was profiled at $1 \mu \mathrm{M}$ against 32 recombinant bromodomains.

4.7.Eurofins KinaseProfiler. Kinase profiling was performed by Eurofins (Dundee, U. K., https://www.eurofins.com/). (R,R)-24a, endo-24c and $(R, R)-\mathbf{3 6 n}$ were profiled at a single concentration of $10 \mu \mathrm{M}$ against a panel of 422 kinases.

4.8. Crystallization and Structure Determination. PCAF and GCN5 BRDs were crystallized by vapor diffusion in sitting drops. For PCAF, crystals grew in a mixture of $1 \mu \mathrm{L}$ protein solution at $16 \mathrm{mg} / \mathrm{ml}(25 \mathrm{mM}$ HEPES, $\mathrm{pH}$ 7.5, $300 \mathrm{mM} \mathrm{NaCl}, 0.5 \mathrm{mM}$ TCEP) and $1 \mu \mathrm{L}$ reservoir solution (100 mM HEPES pH 8.2, 26\% PEG10000 (v/v), 4\% glycol) at $4{ }^{\circ} \mathrm{C}$. Then overnight soaking of compound $\mathbf{1 2}$ was performed. For GCN5, crystals with compound $(R, R)$-36n were grown by mixing $1 \mu \mathrm{L}$ of the protein $(12$ $\mathrm{mg} / \mathrm{mL}$ and $4 \mathrm{mM}$ final ligand concentration) with an equal volume of reservoir solution containing $0.2 \mathrm{M}$ ammonium acetate, $0.1 \mathrm{M}$ Tris $\mathrm{pH} 8.5,25 \% \mathrm{w} / \mathrm{v}$ polyethylene glycol 
3350 at $20{ }^{\circ} \mathrm{C}$. Diffraction quality crystals grew within 5-7 days. All crystals were cryoprotected with reservoir solution supplemented with $20 \%$ glycerol (v/v) before being plunge-frozen in liquid nitrogen.

Diffraction data were collected at the Shanghai Synchrotron Light Source (Shanghai, China). Data were indexed, integrated and scaled using HKL2000 ${ }^{36}$ or XDS. ${ }^{37}$ Structures were solved by molecular replacement with Phaser $^{38}$ using $5 \mathrm{mkx} . \mathrm{pdb}$ as template for PCAF bromodomain and 5mlj.pdb as template for GCN5 bromodomain. Initial models were refined alternating cycles of automatic refinement with Phenix.refine ${ }^{39,40}$ and manual model building with WinCOOT 0.8.9.41 The structure figures were prepared using Pymol. For the data collection and refinement statistics, see Supporting Information Table S4.

4.9. NanoBRET. HEK 293 T cells $\left(4 \times 10^{5} / \mathrm{ml}\right)$ were plated in 6 -well plate and cotransfected with Histone H3.3-Halotag and PCAF-Nanoluciferase (Promega). Twenty hours after transfection, cells were digested, collected and exchanged into Phenol redfree DMEM containing 4\% FBS. Cell density was adjusted to $2 \times 10^{5} / \mathrm{ml}$ and then replated into a 96-well assay white plate (Corning Costar \#3917) in the absence (blank control) or the presence of $100 \mathrm{nM}$ NanoBRET 618 fluorescent ligand (Promega N1661). Compounds or DMSO (vehicle control) were diluted using media and then added into a 96-well plate at indicated concentrations. After that, the 96-well plate was incubated for $18 \mathrm{~h}$ at $37^{\circ} \mathrm{C}$ in the presence of $5 \% \mathrm{CO}_{2}$. NanoBRET Nano-Glo substrate (Promega N1661) was diluted 100 times using media and then added $25 \mu \mathrm{L}$ to each sample well. Readings were recorded within 10 minutes using Thermo Scientific Varioskan LUX equipped with 460/80 nm bandpass and $610 \mathrm{~nm}$ longpass filter module. The corrected BRET ratio was calculated as the following formula: NanoBRET corrected ratio $=$ Ligand $(610 \mathrm{~nm} / 460 \mathrm{~nm})-$ blank control $(610 \mathrm{~nm} / 460 \mathrm{~nm})$. BRET 
ratios are expressed as milliBRET units (mBU), where $1 \mathrm{mBU}$ corresponds to the corrected BRET ratio multiplied by 1000 .

4.10. RNA-seq. Total RNA was extracted using the TRIzol reagent according to the manufacturer's protocol. RNA purity and quantification were evaluated using a NanoDrop 2000 spectrophotometer (Thermo Scientific, USA). RNA integrity was assessed using the Agilent 2100 Bioanalyzer (Agilent Technologies, Santa Clara, CA, USA). Then the libraries were constructed using TruSeq Stranded mRNA LT Sample Prep Kit (Illumina, San Diego, CA, USA) according to the manufacturer's instructions. The transcriptome sequencing and analysis were conducted by OE Biotech Co., Ltd. (Shanghai, China).

The libraries were sequenced on an Illumina HiSeq X Ten platform and $150 \mathrm{bp}$ paired-end reads were generated. Raw data (raw reads) of fastq format were firstly processed using Trimmomatic. After removing low quality reads and reads containing adapter or ploy-N from raw data, the clean reads were mapped to the human genome using HISAT2.

FPKM value of each gene was calculated using Cufflinks, and the read counts of each gene were obtained by HTSeq-count. Differential expression analysis was performed using the DESeq (2012) R package. P value $<0.05$ and fold change $>1.5$ or $<1 / 1.5$ was set as the threshold for significantly differential expression.

4.11. Microsomal Stability Assay. $(R, R)-36 n(1 \mu \mathrm{M})$ was incubated with 0.5 $\mathrm{mg} / \mathrm{mL}$ human liver microsomes. NADPH was maintained at $1 \mathrm{mM}$ in $1000 \mu \mathrm{L}$ of reaction volume. The reaction was then evaluated at $0,5,15,30$, and $45 \mathrm{~min}$ and was terminated by the addition of acetonitrile. Samples were centrifuged for $15 \mathrm{~min}$ at 6000 
rpm and the supernatant analyzed using LC-MS. Percentage parent remaining was calculated considering percent parent area at $0 \mathrm{~min}$ as $100 \%$.

4.12. Plasma protein binding. Plasma protein binding was measured using previously published protocol. ${ }^{42}$

4.13. Rats pharmacokinetic studies. Animal studies were conducted under the approval of the Experimental Animal Management Committee of Sichuan University. The pharmacokinetics analysis of $(R, R)$-36n was conducted in male Sprague-Dawley rats. The 6 to 8 week old Sprague-Dawley rats were treated with a single dose of $(R, R)$ 36n at $10 \mathrm{mg} / \mathrm{kg}$ by intravenous tail vein injection and oral gavage administration $(2.5 \%$ (v/v) ethanol and $2.5 \%$ tween- 80 in saline, $\mathrm{pH} 7.0)$. Serial blood samples $(200 \mu \mathrm{L})$ were collected from jugular vein at designated times. Blood samples were put on ice and centrifuged to obtain plasma samples $\left(6800 \times \mathrm{g}, 6\right.$ min under $\left.4{ }^{\circ} \mathrm{C}\right)$ within 2 hours. All blood samples were stored at approximately at $-80{ }^{\circ} \mathrm{C}$ until analysis.

The blood samples were prepared for analysis by placing a $20 \mu \mathrm{L}$ aliquot into a 96well plate followed by the addition of $400 \mu \mathrm{L} \mathrm{MeOH}$ of acetonitrile containing 100 $\mathrm{ng} / \mathrm{mL}$ IS. The mixture was vortexed for $1 \mathrm{~min}$ and centrifuged at $18000 \times \mathrm{g}$ for $7 \mathrm{~min}$. An aliquot of $1 \mu \mathrm{L}$ supernatant was injected for LC-MS/MS analysis. Noncompartmental pharmacokinetic parameters were fitted using DAS software (Enterprise, version 2.0, Mathematical Pharmacology Professional Committee of China).

\section{ASSOCIATED CONTENT}




\section{Supporting Information}

Flowchart of hits identification against PCAF bromodomain; DSF results of test compounds against a panel of 12 bromodomains; BROMOscan assay of $(R, R)-\mathbf{3 6 n}$ against 32 bromodomains; Kinase inhibition profiles of $(R, R)-\mathbf{2 4 a}$, endo-24c and $(R, R)$ 36n; ITC curves of selected compounds against PCAF; X-ray data collection and refinement statistics; ${ }^{1} \mathrm{H}$ spectra, ${ }^{13} \mathrm{C}$ NMR spectra; HRMS spectra; chiral HPLC traces (PDF).

Molecular formula strings (CSV)

\section{Accession Codes}

Atomic coordinates and structure factors have been deposited in the Protein Data Bank under the following accession codes: $6 \mathrm{~J} 3 \mathrm{O}$ (PCAF/compound 12), 6J3P (GCN5/compound $(R, R)-36 n)$. Authors will release the atomic coordinates and experimental data upon article publication.

\section{AUTHOR INFORMATION}

\section{Corresponding Author}

*Tel.: +86-28-85164063; Fax: +86-28-85164060; E-mail: yangsy@scu.edu.cn (S.Y.)

\section{ORCID}

Shengyong Yang: 0000-0001-5147-3746

\section{Author Contributions}

\# L. H., H. L., and L. L. contributed equally to this work.

\section{Notes}

The authors declare no competing financial interest. 


\section{ACKNOWLEDGEMENTS}

This work was supported by the National Natural Science Foundation of China (81573349, 81773633, and 21772130), National Science and Technology Major Project (2018ZX09711002-014-002, 2018ZX09711002-011-019, 2018ZX09201018, and 2018ZX09711003-003-006), and 1.3.5 project for disciplines of excellence, West China Hospital, Sichuan University. The authors thank the staff from BL17U1, BL18U, BL19U1 beamlines of National Facility for Protein Science Shanghai (NFPS) at Shanghai Synchrotron Radiation Facility for assistance during data collection.

\section{ABBREVIATIONS USED}

BET, bromodomain and extra terminal domain; HAT, histone acetyltransferase; BRD4(1), bromodomain containing protein 4, first bromodomain; $\mathrm{S}_{\mathrm{N}} \mathrm{Ar}$, nucleophilic aromatic substitution; BRD9, bromodomain containing protein 9; BAZ2, bromodomain adjacent to zinc finger domain 2; BRPF, bromodomain and PHD finger; CECR2, cat eye syndrome chromosome region, candidate 2; FALZ, fetal Alzheimer-50 clone 1 protein; TAF1, TBP-associated factor RNA polymerase 1; EP300, E1A-binding protein, $300 \mathrm{kDa}$; DSF, differential scanning fluorimetry; GCN5, general control nonderepressible 5; KAT2, lysine acetyl-transferase 2; PCAF, p300/CBPassociated factor; HTRF, homogeneous time-Resolved fluorescence; ITC, isothermal titration calorimetry; DMAP, 4-Dimethylaminepyridine; RNA-seq, RNA-sequencing

\section{REFERENCES}

1. Filippakopoulos, P.; Picaud, S.; Mangos, M.; Keates, T.; Lambert, J. P.; Barsyte- 
Lovejoy, D.; Felletar, I.; Volkmer, R.; Muller, S.; Pawson, T.; Gingras, A. C.; Arrowsmith, C. H.; Knapp, S. Histone recognition and large-scale structural analysis of the human bromodomain family. Cell 2012, 149, 214-231.

2. Filippakopoulos, P.; Knapp, S. Targeting bromodomains: epigenetic readers of lysine acetylation. Nat Rev Drug Discov 2014, 13, 337-356.

3. Romero, F. A.; Taylor, A. M.; Crawford, T. D.; Tsui, V.; Cote, A.; Magnuson, S. Disrupting acetyl-lysine recognition: progress in the development of bromodomain inhibitors. J Med Chem 2016, 59, 1271-1298.

4. Liu, Z.; Wang, P.; Chen, H.; Wold, E. A.; Tian, B.; Brasier, A. R.; Zhou, J. Drug discovery targeting bromodomain-containing protein 4. J Med Chem 2017, 60, 45334558.

5. Dawson, M. A.; Prinjha, R. K.; Dittmann, A.; Giotopoulos, G.; Bantscheff, M.; Chan, W.-I.; Robson, S. C.; Chung, C.-w.; Hopf, C.; Savitski, M. M.; Huthmacher, C.; Gudgin, E.; Lugo, D.; Beinke, S.; Chapman, T. D.; Roberts, E. J.; Soden, P. E.; Auger, K. R.; Mirguet, O.; Doehner, K.; Delwel, R.; Burnett, A. K.; Jeffrey, P.; Drewes, G.; Lee, K.; Huntly, B. J. P.; Kouzarides, T. Inhibition of BET recruitment to chromatin as an effective treatment for MLL-fusion leukaemia. Nature 2011, 478, 529-533.

6. Delmore, J. E.; Issa, G. C.; Lemieux, M. E.; Rahl, P. B.; Shi, J.; Jacobs, H. M.; Kastritis, E.; Gilpatrick, T.; Paranal, R. M.; Qi, J.; Chesi, M.; Schinzel, A. C.; McKeown, M. R.; Heffernan, T. P.; Vakoc, C. R.; Bergsagel, P. L.; Ghobrial, I. M.; Richardson, P. G.; Young, R. A.; Hahn, W. C.; Anderson, K. C.; Kung, A. L.; Bradner, J. E.; Mitsiades, C. S. BET bromodomain inhibition as a therapeutic strategy to target c-Myc. Cell 2011, 
$146,904-917$.

7. Nicodeme, E.; Jeffrey, K. L.; Schaefer, U.; Beinke, S.; Dewell, S.; Chung, C. W.; Chandwani, R.; Marazzi, I.; Wilson, P.; Coste, H.; White, J.; Kirilovsky, J.; Rice, C. M.; Lora, J. M.; Prinjha, R. K.; Lee, K.; Tarakhovsky, A. Suppression of inflammation by a synthetic histone mimic. Nature 2010, 468, 1119-1123.

8. Picaud, S.; Wells, C.; Felletar, I.; Brotherton, D.; Martin, S.; Savitsky, P.; DiezDacal, B.; Philpott, M.; Bountra, C.; Lingard, H.; Fedorov, O.; Muller, S.; Brennan, P. E.; Knapp, S.; Filippakopoulos, P. RVX-208, an inhibitor of BET transcriptional regulators with selectivity for the second bromodomain. Proc Natl Acad Sci USA 2013, $110,19754-19759$.

9. Shu, S.; Lin, C. Y.; He, H. H.; Witwicki, R. M.; Tabassum, D. P.; Roberts, J. M.; Janiszewska, M.; Huh, S. J.; Liang, Y.; Ryan, J.; Doherty, E.; Mohammed, H.; Guo, H.; Stover, D. G.; Ekram, M. B.; Brown, J.; D'Santos, C.; Krop, I. E.; Dillon, D.; McKeown, M.; Ott, C.; Qi, J.; Ni, M.; Rao, P. K.; Duarte, M.; Wu, S. Y.; Chiang, C. M.; Anders, L.; Young, R. A.; Winer, E.; Letai, A.; Barry, W. T.; Carroll, J. S.; Long, H.; Brown, M.; Liu, X. S.; Meyer, C. A.; Bradner, J. E.; Polyak, K. Response and resistance to BET bromodomain inhibitors in triple-negative breast cancer. Nature 2016, 529, 413-417.

10. Theodoulou, N. H.; Tomkinson, N. C.; Prinjha, R. K.; Humphreys, P. G. Progress in the development of non-BET bromodomain chemical probes. ChemMedChem 2016, $11,477-487$.

11. Moustakim, M.; Clark, P. G. K.; Hay, D. A.; Dixon, D. J.; Brennan, P. E. Chemical probes and inhibitors of bromodomains outside the BET family. Medchemcomm 2016, 
7, 2246-2264.

12. Clegg, M. A.; Tomkinson, N. C. O.; Prinjha, R. K.; Humphreys, P. G. Advancements in the development of non-BET bromodomain chemical probes. ChemMedChem 2019, 14, 362-385.

13. Lau, O. D.; Courtney, A. D.; Vassilev, A.; Marzilli, L. A.; Cotter, R. J.; Nakatani, Y.; Cole, P. A. P300/CBP-associated factor histone acetyltransferase processing of a peptide substrate. Kinetic analysis of the catalytic mechanism. J Biol Chem 2000, 275, 21953-21959.

14. Linares, L. K.; Kiernan, R.; Triboulet, R.; Chable-Bessia, C.; Latreille, D.; Cuvier, O.; Lacroix, M.; Le Cam, L.; Coux, O.; Benkirane, M. Intrinsic ubiquitination activity of PCAF controls the stability of the oncoprotein Hdm2. Nat Cell Biol 2007, 9, 331338.

15. Mujtaba, S.; He, Y.; Zeng, L.; Farooq, A.; Carlson, J. E.; Ott, M.; Verdin, E.; Zhou, M. M. Structural basis of lysine-acetylated HIV-1 Tat recognition by PCAF bromodomain. Mol Cell 2002, 9, 575-586.

16. Wang, T.; Yao, W.; Shao, Y.; Zheng, R.; Huang, F. PCAF fine-tunes hepatic metabolic syndrome, inflammatory disease, and cancer. J Cell Mol Med 2018, 22, 5787 5800.

17. Zeng, L.; Li, J.; Muller, M.; Yan, S.; Mujtaba, S.; Pan, C.; Wang, Z.; Zhou, M. M. Selective small molecules blocking HIV-1 Tat and coactivator PCAF association. J Am Chem Soc 2005, 127, 2376-2377.

18. Hu, P.; Wang, X.; Zhang, B.; Zhang, S.; Wang, Q.; Wang, Z. Fluorescence 
polarization for the evaluation of small-molecule inhibitors of PCAF BRD/Tat-AcK50 association. ChemMedChem 2014, 9, 928-931.

19. Navratilova, I.; Aristotelous, T.; Picaud, S.; Chaikuad, A.; Knapp, S.; Filappakopoulos, P.; Hopkins, A. L. Discovery of new bromodomain scaffolds by biosensor fragment screening. ACS Med Chem Lett 2016, 7, 1213-1218.

20. Chaikuad, A.; Lang, S.; Brennan, P. E.; Temperini, C.; Fedorov, O.; Hollander, J.; Nachane, R.; Abell, C.; Muller, S.; Siegal, G.; Knapp, S. Structure-based identification of inhibitory fragments targeting the p300/CBP-associated factor bromodomain. $J$ Med Chem 2016, 59, 1648-1653.

21. Albrecht, B. K.; Cote, A.; Crawford, T.; Duplessis, M.; Good, A. C.; Leblanc, Y.; Magnuson, S.; Nasveschuk, C. G.; Pastor, R.; Romero, F. A.; Taylor, A. M. Therapeutic Compounds and Uses Thereof. WO 2016/036873 A1, 2016.

22. Albrecht, B. K.; Cote, A.; Crawford, T.; Duplessis, M.; Good, A. C.; Leblanc, Y.; Magnuson, S.; Nasveschuk, C. G.; Pastor, R.; Romero, F. A.; Taylor, A. M. Phthalazine Derivatives of Forumula (I) as PCAF and GCN5 Inhibitors for Use in the Treatment of Cancer. WO 2016/036954 A1, 2016.

23. Albrecht, B. K.; Burdick, D. J.; Cote, A.; Duplessis, M.; Nasveschuk, C. G.; Taylor, A. M. Pyridazinone Derivatives and Their Use in the Treatment of Cancer. WO 2016/112298 A1, 2016.

24. Moustakim, M.; Clark, P. G.; Trulli, L.; Fuentes de Arriba, A. L.; Ehebauer, M. T.; Chaikuad, A.; Murphy, E. J.; Mendez-Johnson, J.; Daniels, D.; Hou, C. D.; Lin, Y. H.; Walker, J. R.; Hui, R.; Yang, H.; Dorrell, L.; Rogers, C. M.; Monteiro, O. P.; Fedorov, 
O.; Huber, K. V.; Knapp, S.; Heer, J.; Dixon, D. J.; Brennan, P. E. Discovery of a PCAF bromodomain chemical probe. Angew Chem Int Ed 2017, 56, 827-831.

25. Humphreys, P. G.; Bamborough, P.; Chung, C. W.; Craggs, P. D.; Gordon, L.; Grandi, P.; Hayhow, T. G.; Hussain, J.; Jones, K. L.; Lindon, M.; Michon, A. M.; Renaux, J. F.; Suckling, C. J.; Tough, D. F.; Prinjha, R. K. Discovery of a potent, cell penetrant, and selective P300/CBP-associated factor (PCAF)/general control nonderepressible 5 (GCN5) bromodomain chemical probe. J Med Chem 2017, 60, 695709.

26. Bassi, Z. I.; Fillmore, M. C.; Miah, A. H.; Chapman, T. D.; Maller, C.; Roberts, E. J.; Davis, L. C.; Lewis, D. E.; Galwey, N. W.; Waddington, K. E.; Parravicini, V.; Macmillan-Jones, A. L.; Gongora, C.; Humphreys, P. G.; Churcher, I.; Prinjha, R. K.; Tough, D. F. Modulating PCAF/GCN5 immune cell function through a PROTAC approach. ACS Chem Biol 2018, 13, 2862-2867.

27. Hay, D. A.; Rogers, C. M.; Fedorov, O.; Tallant, C.; Martin, S.; Monteiro, O. P.; Müller, S.; Knapp, S.; Schofield, C. J.; Brennan, P. E. Design and synthesis of potent and selective inhibitors of BRD7 and BRD9 bromodomains. MedChemComm 2015, 6, 1381-1386.

28. Chen, P.; Chaikuad, A.; Bamborough, P.; Bantscheff, M.; Bountra, C.; Chung, C.w.; Fedorov, O.; Grandi, P.; Jung, D.; Lesniak, R.; Lindon, M.; Müller, S.; Philpott, M.; Prinjha, R.; Rogers, C.; Selenski, C.; Tallant, C.; Werner, T.; Willson, T. M.; Knapp, S.; Drewry, D. H. Discovery and characterization of GSK2801, a selective chemical probe for the bromodomains BAZ2A and BAZ2B. J Med. Chem. 2015, 59, 1410-1424. 
29. Xiang, Q.; Wang, C.; Zhang, Y.; Xue, X.; Song, M.; Zhang, C.; Li, C.; Wu, C.; Li, K.; Hui, X.; Zhou, Y.; Smaill, J. B.; Patterson, A. V.; Wu, D.; Ding, K.; Xu, Y. Discovery and optimization of 1-(1H-indol-1-yl)ethanone derivatives as CBP/EP300 bromodomain inhibitors for the treatment of castration-resistant prostate cancer. Eur $J$ Med Chem 2018, 147, 238-252.

30. Unzue, A.; Zhao, H.; Lolli, G.; Dong, J.; Zhu, J.; Zechner, M.; Dolbois, A.; Caflisch, A.; Nevado, C. The "gatekeeper" residue influences the mode of binding of acetyl indoles to bromodomains. J Med Chem 2016, 59, 3087-3097.

31. Van Steijvoort, B. F.; Kaval, N.; Kulago, A. A.; Maes, B. U. W. Remote functionalization: palladium-catalyzed $\mathrm{C} 5(\mathrm{sp} 3)-\mathrm{H}$ arylation of 1-boc-3aminopiperidine through the use of a bidentate directing group. ACS Catalysis 2016, 6 , 4486-4490.

32. Crawford, T. D.; Tsui, V.; Flynn, E. M.; Wang, S.; Taylor, A. M.; Cote, A.; Audia, J. E.; Beresini, M. H.; Burdick, D. J.; Cummings, R.; Dakin, L. A.; Duplessis, M.; Good, A. C.; Hewitt, M. C.; Huang, H. R.; Jayaram, H.; Kiefer, J. R.; Jiang, Y.; Murray, J.; Nasveschuk, C. G.; Pardo, E.; Poy, F.; Romero, F. A.; Tang, Y.; Wang, J.; Xu, Z.; Zawadzke, L. E.; Zhu, X.; Albrecht, B. K.; Magnuson, S. R.; Bellon, S.; Cochran, A. G. Diving into the water: inducible binding conformations for BRD4, TAF1(2), BRD9, and CECR2 bromodomains. J Med Chem 2016, 59, 5391-5402.

33. Machleidt, T.; Woodroofe, C. C.; Schwinn, M. K.; Mendez, J.; Robers, M. B.; Zimmerman, K.; Otto, P.; Daniels, D. L.; Kirkland, T. A.; Wood, K. V. NanoBRET--a novel BRET platform for the analysis of protein-protein interactions. ACS Chem Biol 
2015, 10, 1797-1804.

34. Niesen, F. H.; Berglund, H.; Vedadi, M. The use of differential scanning fluorimetry to detect ligand interactions that promote protein stability. Nat Protoc 2007, 2, 22122221.

35. Quinn, E.; Wodicka, L.; Ciceri, P.; Pallares, G.; Pickle, E.; Torrey, A.; Floyd, M.; Hunt, J.; Treiber, D. BROMOscan a high throughput, quantitative ligand binding platform identifies best-in-class bromodomain inhibitors from a screen of mature compounds targeting other protein classes. Cancer Res. 2013, 73, 4238.

36. Otwinowski, Z.; Minor, W. Processing of X-ray diffraction data collected in oscillation mode. Method Enzymol 1997, 276, 307-326.

37. Kabsch, W. Xds. Acta Crystallogr D Biol Crystallogr 2010, 66, 125-132.

38. McCoy, A. J.; Grosse-Kunstleve, R. W.; Adams, P. D.; Winn, M. D.; Storoni, L. C.; Read, R. J. Phaser crystallographic software. J Appl Crystallogr 2007, 40, 658-674.

39. Adams, P. D.; Afonine, P. V.; Bunkoczi, G.; Chen, V. B.; Davis, I. W.; Echols, N.; Headd, J. J.; Hung, L. W.; Kapral, G. J.; Grosse-Kunstleve, R. W.; McCoy, A. J.; Moriarty, N. W.; Oeffner, R.; Read, R. J.; Richardson, D. C.; Richardson, J. S.; Terwilliger, T. C.; Zwart, P. H. PHENIX: a comprehensive Python-based system for macromolecular structure solution. Acta Crystallogr D Biol Crystallogr 2010, 66, 213221.

40. Afonine, P. V.; Grosse-Kunstleve, R. W.; Echols, N.; Headd, J. J.; Moriarty, N. W.; Mustyakimov, M.; Terwilliger, T. C.; Urzhumtsev, A.; Zwart, P. H.; Adams, P. D. Towards automated crystallographic structure refinement with phenix.refine. Acta 
Crystallogr D Biol Crystallogr 2012, 68, 352-367.

41. Emsley, P.; Lohkamp, B.; Scott, W. G.; Cowtan, K. Features and development of Coot. Acta Crystallogr D 2010, 66, 486-501.

42. Mitchell, L. H.; Boriack-Sjodin, P. A.; Smith, S.; Thomenius, M.; Rioux, N.; Munchhof, M.; Mills, J. E.; Klaus, C.; Totman, J.; Riera, T. V.; Raimondi, A.; Jacques, S. L.; West, K.; Foley, M.; Waters, N. J.; Kuntz, K. W.; Wigle, T. J.; Scott, M. P.; Copeland, R. A.; Smith, J. J.; Chesworth, R. Novel oxindole sulfonamides and sulfamides: EPZ031686, the first orally bioavailable small molecule SMYD3 inhibitor. ACS Med Chem Lett 2016, 7, 134-138. 
Table of Contents Graphic

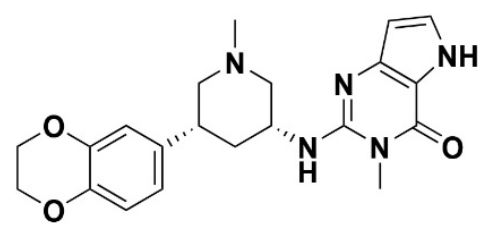

$(R, R)-36 n$

PCAF

HTRF IC $50=7 \mathrm{nM}$

ITC $K_{D}=78 \mathrm{nM}$

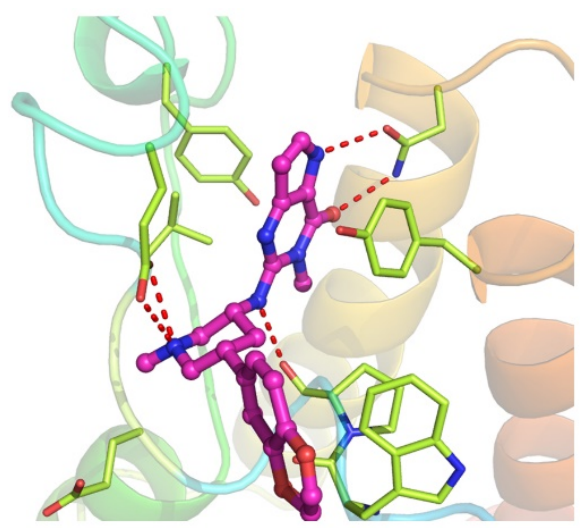

